MARIA CRISTINA ALVES DOS SANTOS PESSI

illustro imago

professoras de arte e seus universos de imagens 
MARIA CRISTINA ALVES DOS SANTOS PESSI

illustro imago

\section{professoras de arte e seus universos de imagens}

Tese apresentada ao Programa de Pós-Graduação em Artes, Área de Concentração Artes Visuais, Linha de Pesquisa Teoria, Ensino e Aprendizagem da Arte, da Escola de Comunicações e Artes da Universidade de São Paulo, como exigência parcial para obtenção do Título de Doutor em Artes, sob a orientação da Profa . Drạ. Regina Stela Barcelos Machado. 
Banca Julgadora da Tese 


\section{RESUMO}

Quais imagens professores de arte selecionam para apresentar aos seus alunos? Esta pergunta desdobra-se em muitas outras perguntas, busca as imagens usadas por professores de arte e toma a própria imagem como substância e objeto de pesquisa. $\mathrm{O}$ texto localiza a problemática no panorama histórico e conceitual, nos âmbitos da arte e da educação, tratando os antecedentes da leitura de imagens pelo prisma do ensino de arte modernista e o desvendar da leitura de imagens no ensino de arte. Através de pesquisa bibliográfica, são abordadas as questões sobre o pensamento moderno e pós-moderno, dirigindo o enfoque para a própria arte. As imagens fotográficas produzidas na pesquisa de campo são consideradas textos visuais e, portanto, igualmente fonte de dados. Foram apreciadas segundo os conceitos studium e punctum de Roland Barthes e segundo os critérios de avaliação da proposta Arts-Based Educational Research de Elliot Eisner. As imagens apresentadas propiciam a reflexão sobre a problemática evidenciada na tese.

Palavras-chave: ensino de arte; artes visuais; imagens; leitura; professores de arte, arte contemporânea

\section{ABSTRACT}

Which images do art teachers select to present to their students? This question unfolds itself into many other questions, searches for images used by art teachers and takes the image itself as object and substance of research. The text places the issue on the historical and conceptual panorama around art and education, treating the image reading antecedents in the light of modern art and the disclosing of image reading in art education. Through bibliographical research, the questions about modern and post-modern thinking are approached, focusing art itself. The photographical images produced in the field research are considered visual texts and, therefore, data source as well. They have been appreciated according to the studium and punctum concepts by Roland Barthes and evaluation criteria of an Arts-Based Educational Research proposal by Elliot Eisner. The images thereby presented contribute to a reflection about the issues evidenced on the thesis.

Keywords: art education; visual arts; images; reading; art teachers, contemporary art 
Para Fabíola 
Num lugar não muito distante, até bem próximo, dentro de mim, ouvi pela primeira vez A lenda das areias.

Quis ser água na fonte.

"Agora eu era"chuva.

Num tempo não muito distante, até bem próximo, ouvi pela primeira vez O filho de um contador de histórias.

Quis ser princesa.

"Agora eu era" a velha. Nestas mudanças um fato permanece: grato reconhecimento

a Regina Machado, que nos ensina através de sua criação. 
"Mas Deus me fez a graça de que eu falasse segundo o que sinto, e de que presumisse coisas dignas destas,que me são dadas; porquanto Ele é o guia da sabedoria, e o emendador dos sábios: porque na mão dele estamos, assim nós, como os nossos discursos, e toda a sabedoria, e a ciência de obrar, e a disciplina. Porque Ele me ensinou a verdadeira ciência destas coisas, que existem: para que saiba a disposição do orbe da terra,

(...)as naturezas dos animais, e os instintos dos brutos, a força dos ventos, e os pensamentos dos homens."

(Livros sapienciais, AT, Sabedoria, 7,15-20)

"Há uma idade em que se ensina o que se sabe; mas vem em seguida outra, em que se ensina o que não se sabe: isso se chama 'pesquisar'. Vem talvez agora a idade de uma outra experiência, a de 'desaprender', de deixar trabalhar o remanejamento imprevisível que o esquecimento impõe à sedimentação dos saberes, das culturas, das crenças que atravessamos.

Essa experiência tem, creio eu, um nome ilustre e fora de moda, que ousarei tomar aqui sem complexo, na própria encruzilhada de sua etimologia: Sapientia: nenhum poder, um pouco de saber, um pouco de sabedoria, e o máximo de sabor possível."

(Roland Barthes, in: Aula, 1978) 
Agradeço

à Universidade de São Paulo - USP

à Escola de Comunicações e Artes - ECA ao Programa de Pós-Graduação em Artes;

à Universidade do Estado de Santa Catarina - UDESC ao Centro de Artes - CEART ao Departamento de Artes Plásticas - DAP;

à Rede Municipal de Ensino de São José e seus professores de arte;

às leitoras competentes e atentas Profa. Dra. Ana Mae Tavares Bastos Barbosa - USP, Profa. Dra. Maria Christina de Souza Lima Rizzi - USP, Profa. Dra. Rejane Galvão Coutinho - UNESP, Profa. Dra. Sandra Regina Ramalho e Oliveira - UDESC;

àqueles que amo e compartilharam comigo este percurso Anita Prado Koneski, Antônio Carlos Autran Alves dos Santos, Carlos Eduardo Alves dos Santos Pessi, Carlos Grisard Pessi, Eli Fernandes Alves dos Santos, José Antônio Dumsch, Maria Beatriz Fernandes Alves dos Santos, Maria Luiza Ferraro, Rachel de Souza Vianna. 
SUMÁRIO

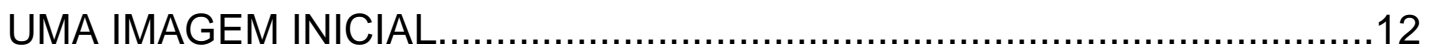

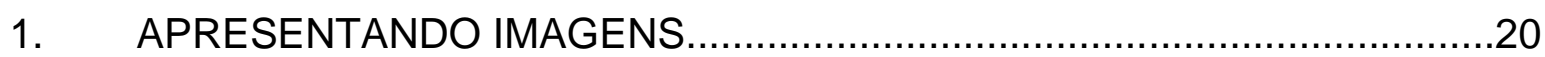

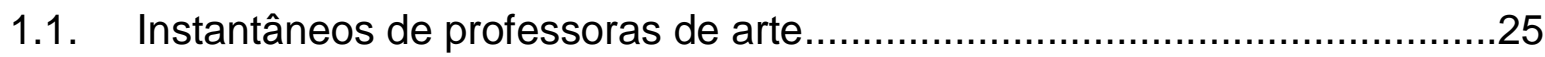

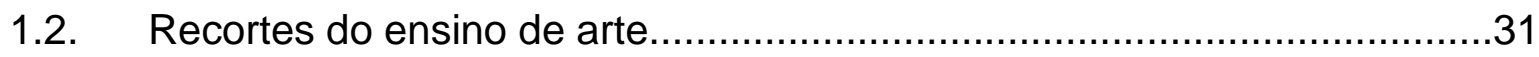

2. REFLEXÕES SOBRE ARTE E SEU ENSINO

2. 1 TEMPOS DA IMAGEM NO ENSINO DE ARTE

2.1.1. Antecedentes da leitura: 0 ensino de arte modernista.....................40

2.1.2. Leitura de imagens: a contemporaneidade no ensino de arte..........48

2.1.3. Leitura de mundo: a estética em Paulo Freire................................57

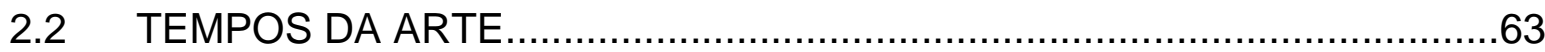

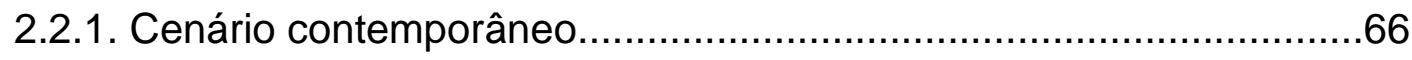

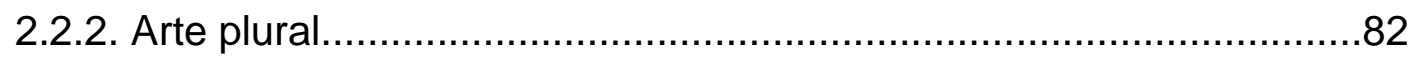

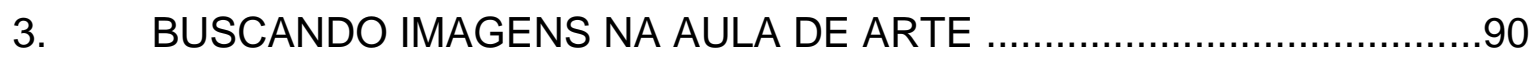

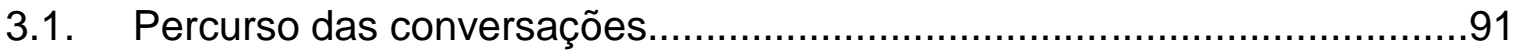

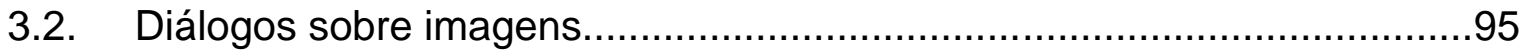

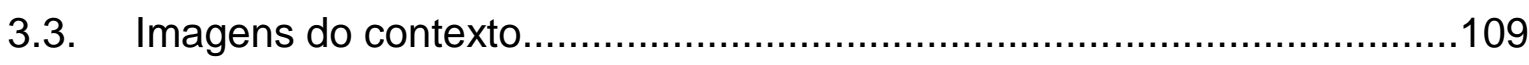

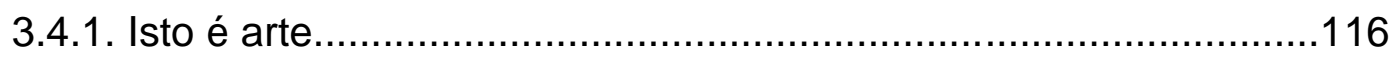

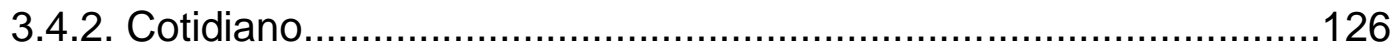

3.4.3. Produções.........................................................................132

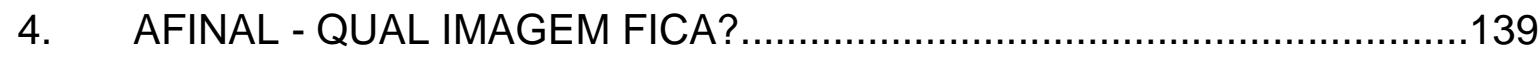

Referências bibliográficas 
Se gosto de uma foto, se ela me perturba, demoro-me com ela.

Que estou fazendo,

durante todo o tempo que permaneço diante dela? Olho-a, escruto-a, como se quisesse saber mais sobre a coisa ou a pessoa que ela representa.

(Roland Barthes, 1984:147) 

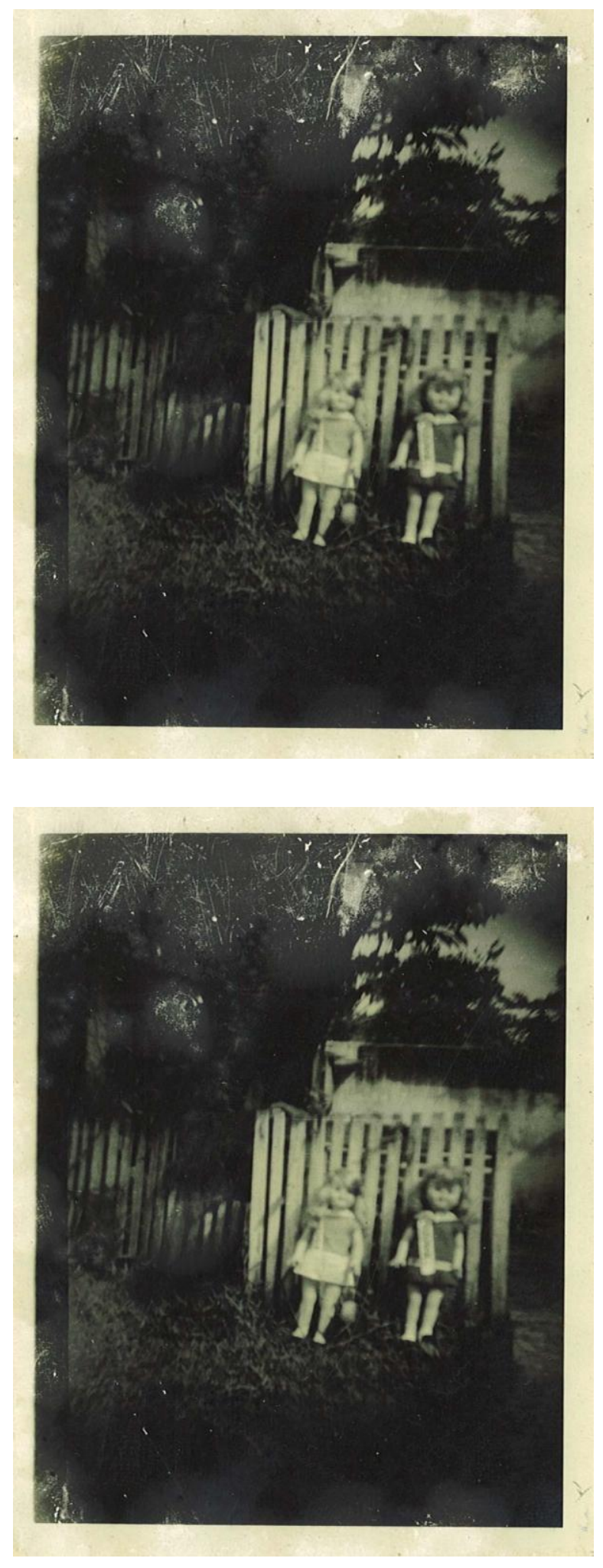

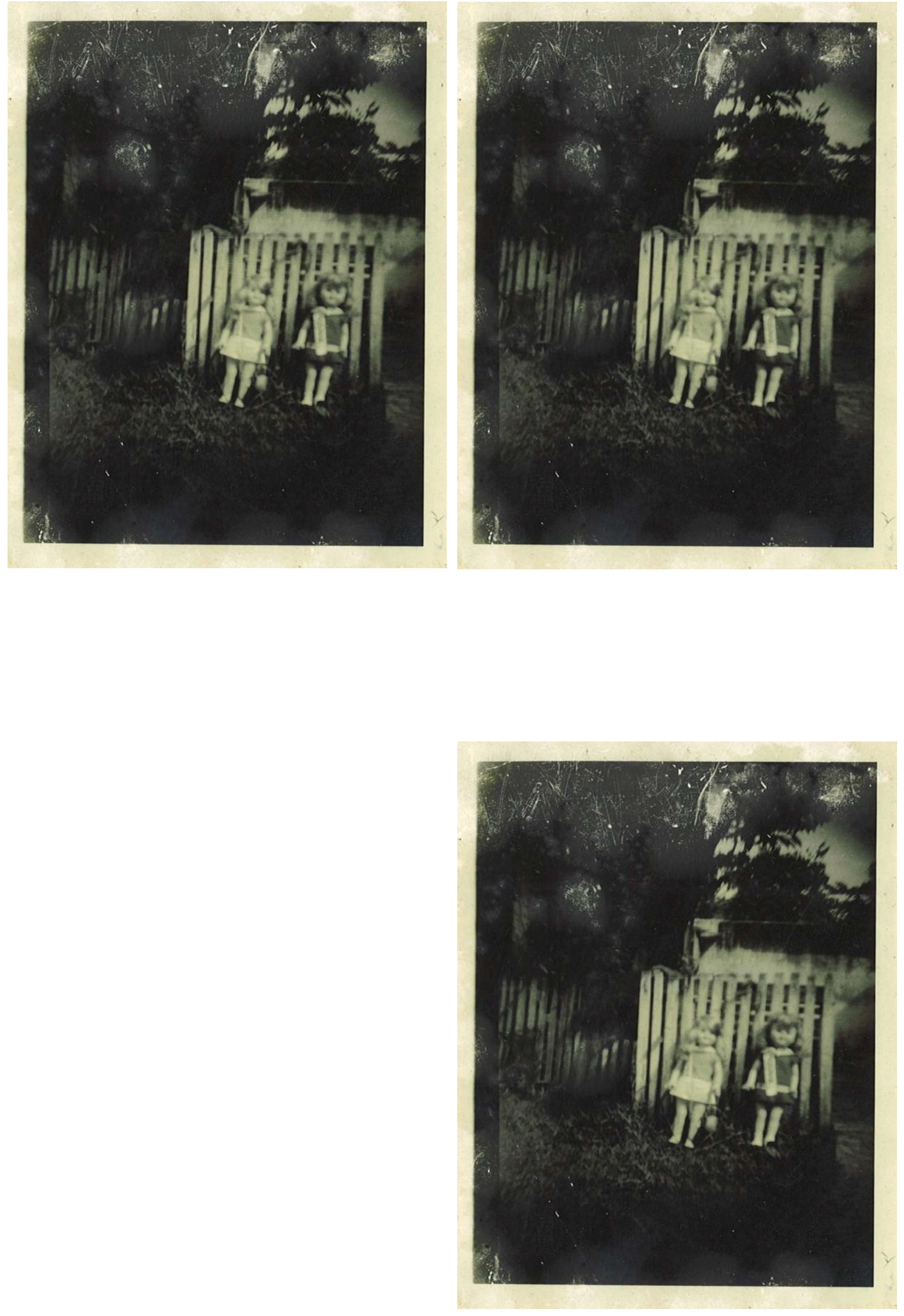


\section{illustro imago}

UMA IMAGEM INICIAL

Illustro imago quer dizer iluminar imagens, dar luz às imagens. É um princípio para este trabalho. Princípio no sentido de inicio, começo, abertura. Mas principalmente, princípio como fundamento e orientação filosófica. Articular palavras, brincar com palavras e suas significações tem sido para mim uma ação de criação e alegria, tal como desenhar, colorir e fotografar. Illustro imago, do latim, surge como título numa referência à leitura de $A$ câmara clara de Roland Barthes. Neste livro Barthes expõe a dificuldade em encontrar uma palavra em

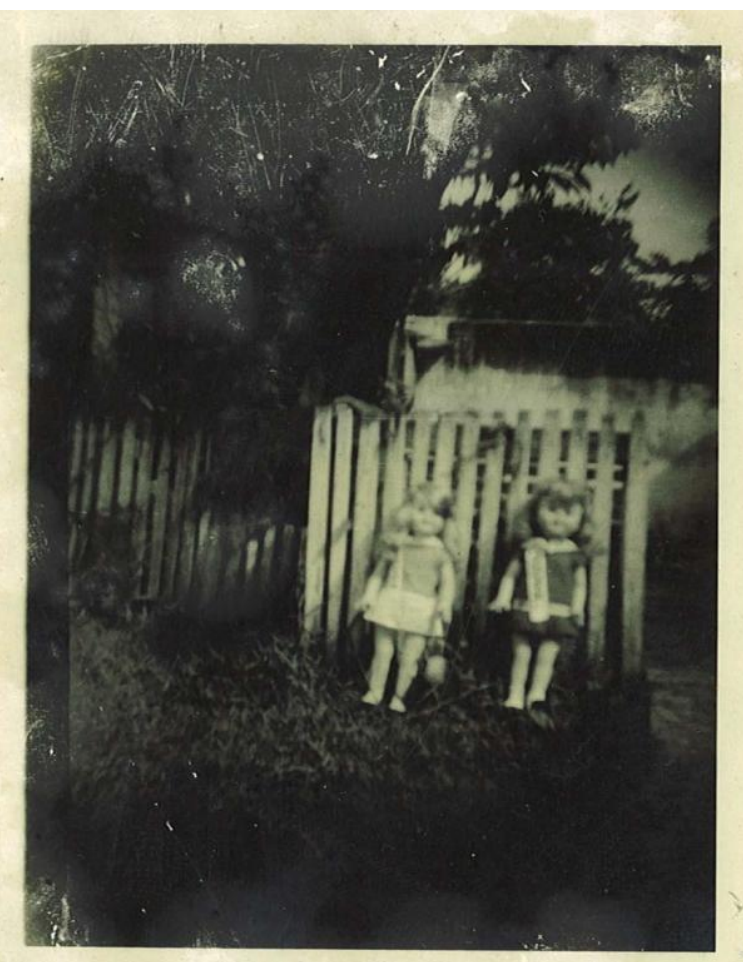
francês que exprimisse uma espécie de interesse geral pela imagem, encontrando no latim o termo studium para afirmar: "É o studium, que não quer dizer, pelo menos de imediato, estudo, mas a aplicação a uma coisa, o gosto por alguém, uma espécie de investimento geral, ardoroso é verdade, mas sem acuidade particular. É pelo studium que me interesso por muitas fotografias" (Barthes, 1984:45). Em contraposição ao studium, Barthes toma a palavra, também em latim, 
punctum para designar o ponto sensível, o que me punge em uma foto. Studium e punctum são conceitos de Barthes sobre fotografias e serão abordados posteriormente no capítulo referente aos procedimentos metodológicos.

Explicando a titulação em latim, digo ainda que illustro imago é a nomeação que tomo para este trabalho por representar a intenção de esclarecer, aclarar, mostrar imagens. É a intenção de elucidar possíveis respostas às seguintes perguntas:

Quais imagens professores de arte selecionam para apresentar aos seus alunos? Serão imagens de obras clássicas? Modernistas? Contemporâneas?

Serão reproduções de obras encontradas em catálogos de exposições? Revistas? Livros de arte?

Serão reproduções da arte européia? Datadas de determinada época?

Serão reproduções da arte de distintos grupos étnicos?

Serão reproduções de obras de artistas locais? Artistas reconhecidos pelas instituições?

Serão imagens produzidas pela cultura visual?

Qual a variedade de imagens que encontramos nas aulas de arte?

Como as professoras utilizam as imagens em aula?

Buscando imagens com professoras de artes para esclarecer essas questões relativas ao ensino de artes visuais, encontrei e clarifiquei algumas das minhas antigas imagens.

Uma das imagens mais remotas que tenho em minha vida vem da casa da minha avó materna. Vem de lá a primeira percepção que tive de mim mesma, muito pequena, talvez uns quatro anos de idade, sentada atrás de uma poltrona amarela. Não recordo o que fazia ali, mas permaneceu uma idéia de lugar de imaginação, refúgio, brincadeira. Aquele meu lugar, entre poucos objetos escolhidos, talvez uma boneca, algumas caixinhas, me permitia também a presença de lápis de cor e papel. Por muitos anos foi o meu lugar preferido dentro da casa, lugar de dar cores a desenhos, a caixinhas, objetos e imaginação. 
A visão da sala era privilegiada naquele meu lugar. Passagem para os dois quartos, para a sala de jantar, cozinha e para a área aberta que unia as peças da casa e a porta de entrada. Podia estar atenta a tudo o que se passava, assim como também facilitava meu retorno de outros lugares imaginados quando ouvia alguém chamar. Algumas vezes um objeto em especial era alvo da minha atenção. Próximo da poltrona amarela havia um console de madeira, pés altos, torneados, um tampo com recorte sinuoso e sobre ele um grande vaso em porcelana. Este vaso de superfície vitrificada era estampado com flores de cores vibrantes, azul, vermelho, roxo, sobre um fundo amarelo. Por muito tempo, o vaso foi motivo dos meus desenhos. Além de uma pequena garatuja esboçando a figura humana, guardada por minha mãe e registrada: Boneco feito $p$ / M.Cristina, 3 anos, o vaso da casa da vó é a primeira memória que tenho de um desenho meu.

Outro lugar de encanto na casa da avó-madrinha era o quintal. Lugar das brincadeiras com minhas irmãs, dos bolos de terra, das perseguições aos gatos, das descobertas das frutas brotando no abacateiro, caquizeiro, mamoeiro e romãzeira. Nas férias de verão, quando lá ficávamos por mais tempo, ajudávamos a distribuir frutas na vizinhança. Este quintal existiu e as experiências lá vividas também; é tão remoto, porém não é a memória que o faz colorido com lápis de cor, realmente o era. Entretanto, tão impossível para algumas crianças na atualidade, pode até simular ficção.

Se na sala da casa configurei a imagem do vaso que decorava e marcava o ambiente, no quintal outra vivência significativa ocorreu. Em meio a aventuras, encontros com lagartas, crisálidas e borboletas, joelho ralado e prego no pé, fiz minha primeira fotografia.

No Natal de 1968, após o retorno de meus pais de uma viagem, fui presenteada com uma pequena máquina fotográfica. Era de brinquedo, produzida num plástico preto muito resistente, quadrada, muito pequena, com um redondo 
botão vermelho numa das superfícies. Para admiração de todos, principalmente dos adultos, era possível fotografar. $O$ alto custo de filmes e revelação foi impedimento para as fotografias constantes, porém impossível esquecer a infinidade de fotos que fiz de plantas, flores e dos gatos que habitavam o quintal. Não sei o destino das fotos, tampouco do brinquedo de fotografar, porém sei que por um cuidado especial de minha mãe, minha avó e até mesmo meu, reencontrei a primeira fotografia que fiz. A foto em preto-e-branco retrata as bonecas que minhas irmãs ganharam naquele Natal. O lugar escolhido para fotografá-las foi 0 quintal.

Escrevo este texto quase ao término de um processo de pesquisa, motivada pelas fotografias que realizei no percurso, motivada pelas imagens que busquei encontrar com as professoras de arte, motivada pela memória das primeiras imagens, desenho e fotografia que realizei. $O$ intuito desta imagem inicial vai além de simplesmente tornar o trabalho mais orgânico - procura enfatizar uma relação pessoal com todas as questões abordadas na pesquisa.

Na pesquisa Experiência estética: um percurso constitutivo de professora de arte, realizada em 2000, ao justificar minha aproximação ao tema, relatei minhas memórias de leitura:

(...) escritas rapidamente durante uma aula, quando afirmava que depois de alfabetizada (no sentido restrito de ler e escrever) não parei mais as possibilidades de leitura. Os livrinhos que meu avô paterno colecionava desde o ano do meu nascimento, e que já tinham sido lidos para mim e minhas irmãs, passaram a ser lidos por mim. Alegria imensa poder ter o livro em minhas mãos, sentir seu papel, textura, cheiro, e sobretudo ter o domínio de fruir a leitura a meu modo, ao meu tempo (Pessi, 2000:3).

No mesmo texto, fazendo referência aos meus primeiros livrinhos, ainda afirmava: "Tomo Pituchinho e Pituchinha certa de estar tratando de ilustrações, para refletir sobre a experiência vivida como leitora de suas imagens, redimensionando o sentido de 'leitura de imagens' ou 'leitura da obra de arte' que o ensino de arte vem empregando" (Idem:7). 
Nesta pesquisa, recorro às minhas memórias de imagens, novamente percebendo que as questões estão conectadas a própria vida. Illustro imago: professoras de arte e seus universos de imagens, além de ser uma pesquisa para indicar possibilidades de superação de uma problemática sobre o uso de imagens na aula de arte, traz no âmbito pessoal uma confirmação das relações com a arte e seu ensino, das relações entre imagem e cotidiano, das relações entre formação profissional e vida. No encontro com as fotografias, este trabalho traz uma animação: "Nesse deserto lúgubre, me surge, de repente, tal foto; ela me anima e eu a animo. Portanto, é assim que devo nomear a atração que a faz existir: uma animação. A própria foto não é em nada animada (não acredito nas fotos 'vivas'), mas ela me anima: é o que toda aventura produz" (Barthes, 1984:37). A fotografia das bonecas me animou, trouxe novo entusiasmo.

O desenho do vaso e a fotografia das bonecas, entre outras, são minhas imagens. São muitas as imagens ao longo de uma vida. São muitas as imagens ao longo de uma formação na área de arte. São várias as obras de arte ou suas representações que desencadearam projetos de ensino. São inúmeras as imagens marcantes entre as pessoas e o cotidiano, o mundo natural, o mundo construído, o poético mundo nano ou o imponente mundo universal.

Illustro imago: professoras de arte e seus universos de imagens trata das imagens selecionadas por professoras de arte do ensino fundamental para serem apresentadas aos alunos. Para abordar esta temática $e$ as perguntas apresentadas no início desta introdução, a tese foi estruturada em três blocos. Estes blocos de reflexão indicam o caminho percorrido para fundamentar a pesquisa. Esta fundamentação por mim escolhida diante de temas de interesse pessoal na área de arte surge de necessidades de ampliação de conhecimento e superação de situações vividas na prática cotidiana com professores de arte nas escolas. As ocasiões a que faço referência são a necessidade constante de orientar respostas ou argumentos sobre arte. Nas escolas, como professora em 
um curso de Licenciatura em Artes Visuais que acompanha alunos-estagiários, futuros professores de artes visuais sou interrogada por alunos do ensino fundamental, diretores, supervisores, professores de outras áreas e também de arte. Nos últimos anos são freqüentes as abordagens sobre: $O$ que é o contemporâneo? O que é moderno e pós-moderno? Quando é arte? É arte ou não é? Que aula posso criar a partir desta obra? Qual conteúdo encontro aqui?

Inicialmente, no Capítulo 1 - Apresentando imagens, destaco a imagem como objeto de pesquisa. Identifico que busco as imagens usadas por professores de arte e esclareço que as imagens por mim produzidas são texto visual para a tese. A imagem enquanto substância e objeto de pesquisa é discutida neste capítulo segundo os termos Arts-Based Educational Research, de Elliot Eisner. Mostro tendências recentes de investigação com base nas produções artísticas. Nos Instantâneos de professoras de arte, mostro fotografias das professoras participantes na pesquisa, aquelas que autorizaram a divulgação, e exponho algumas informações sobre as professoras e sobre as escolas. Em Recortes do ensino de arte, organizo o texto em diálogo com a obra de Ana Mae Barbosa, por tratar-se de uma localização da problemática no panorama histórico e conceitual.

O bloco que segue, Capítulo 2 - Reflexões sobre arte e seu ensino, apresenta a pesquisa bibliográfica no âmbito da arte e da educação, dividindo-se em dois subtítulos: Tempos da imagem no ensino da arte e Tempos da arte. No primeiro tomo o termo leitura como parâmetro. $O$ texto aborda os antecedentes da leitura de imagens pelo prisma do ensino de arte modernista e o desvendar da leitura de imagens no ensino de arte. Para tratar de leitura também como leitura de mundo, retornei à educação e à estética na obra de Paulo Freire, com vistas a melhor apresentar um entendimento de leitura de imagens. Se a alfabetização é imprescindível para o acesso à cidadania, num tempo em que as imagens se multiplicam e diversificam, penso que o acesso à compreensão das imagens é também imprescindível à cidadania. A literatura produzida por Paulo Freire foi 
fundamental para o levantamento dos critérios - cotidiano e produção - para a seleção e análise das fotografias.

Neste mesmo bloco de discussões, sob o tema Tempos da arte introduzo as reflexões acerca das mudanças no mundo da arte. Através de pesquisa bibliográfica e leituras diversas descrevo um cenário contemporâneo visando acompanhar o debate sobre o tema moderno / pós-moderno. Em seqüência, com o subtítulo Arte plural, aprofundo as questões sobre o pensamento moderno e pós-moderno, dirigindo o enfoque para a própria arte. Para esta discussão 0 pensamento de Arthur Danto, expresso em seus escritos, foi um dos fundamentos, e Marcel Duchamp foi o artista a quem recorri para compreender a crítica à noção de obra de arte, a crítica a princípios formais e para o entendimento de arte como pensamento. A leitura dos autores Arthur Efland e Kerry Freedman foram relevantes para refletir os temas tratados neste capítulo no âmbito do ensino de arte. Destaco também a importância do livro Arte/Educação Contemporânea: consonâncias internacionais, organizado por Ana Mae Barbosa, onde se encontram publicados os artigos de pesquisadores internacionais que abordam o ensino de arte pós-moderno.

Considerando o segundo bloco de discussões, encaminhei a pesquisa em campo e, depois de realizada, elaborei o Capítulo 3 - Buscando imagens na aula de arte, no qual descrevo a pesquisa realizada com professores de arte da Rede Municipal de Ensino do Município de São José, localizado próximo a Florianópolis. Em três subtítulos - Percurso das conversações, Diálogos sobre imagens, Imagens do contexto - divido as informações entre os procedimentos metodológicos, os dados obtidos e a análise. Os dados mais considerados foram as fontes fotográficas e estas foram analisadas segundo categorias pós-definidas organizadas de acordo com os fundamentos teóricos da tese. As fotografias, ou a iconografia recolhida, foram apreciadas sempre em conexão com o conceito "conscientização" de Paulo Freire, segundo os conceitos studium e punctum de Roland Barthes, e segundo os critérios de avaliação de uma proposta de Arts- 
Based Educational Research - iluminating effect, generativity, incisiveness, generalizability. ${ }^{1}$ Estes fundamentos da análise deram origem a criação de critérios definidos durante a apreciação das fotos. Ao observar cada fotografia, orientada pelo tema da pesquisa, perguntei: o que revela? O que produz? O que aprofunda? O que amplia? As respostas, isto é, novas perguntas, são apresentadas em ensaios. Estes ensaios mais que uma metodologia de análise são um modo pessoal de escrever.

Por uma repetição de elementos da foto ou variação de contexto, as fotografias foram divididas em: Isto é arte - as imagens apresentadas na sala de aula; Cotidiano - algumas representações do universo visual das professoras; Produções - criações produzidas pelas professoras. Acredito que as imagens apresentadas nestes três grupos realmente contribuirão para refletir sobre a problemática evidenciada na tese.

\footnotetext{
${ }^{1}$ Faço a opção, por um cuidado de interpretação, de não traduzir estes termos de avaliação até que sejam desenvolvidos no texto.
} 


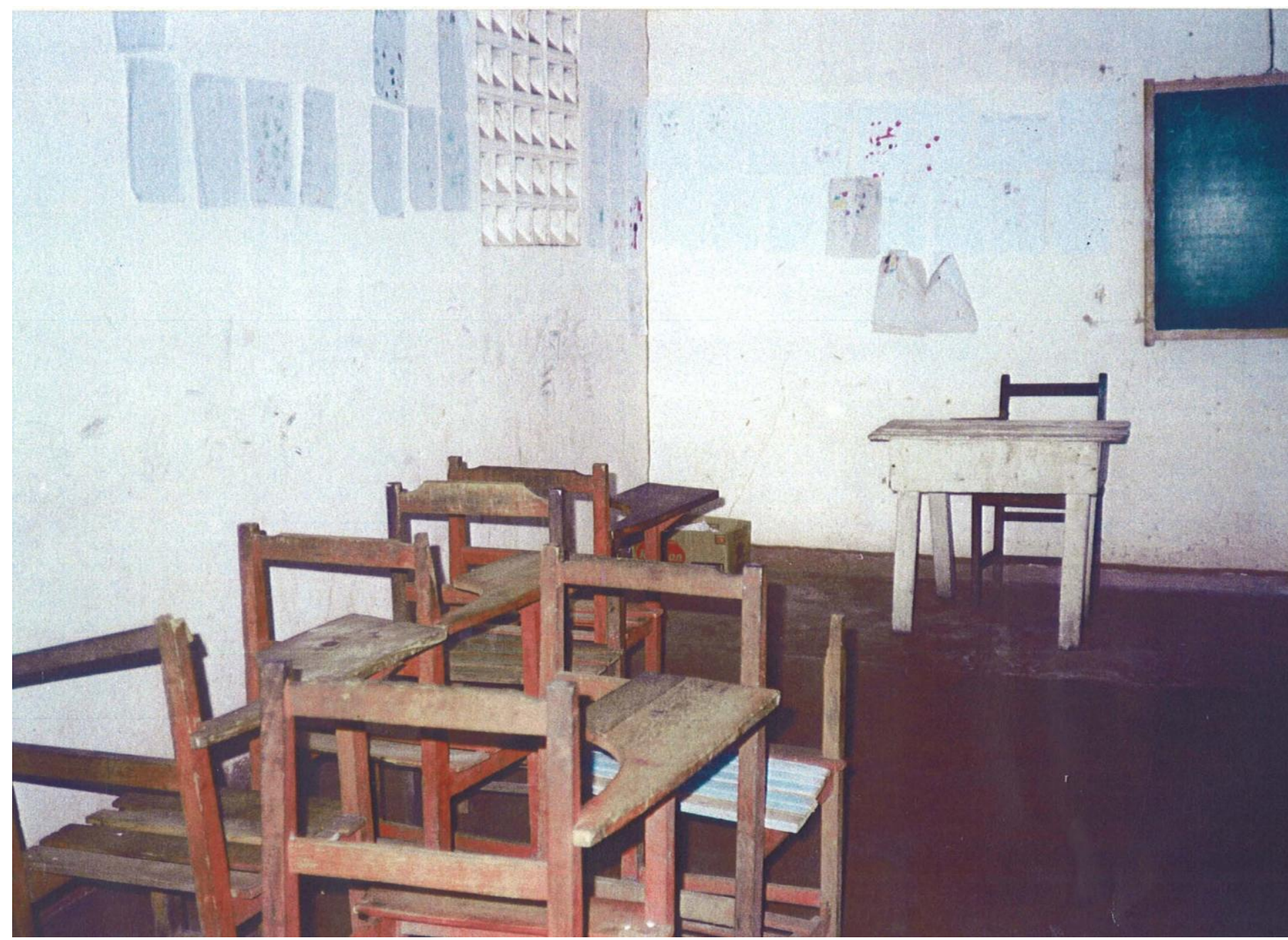

1. APRESENTANDO IMAGENS

A quantidade de imagens que o mundo nos dá a ver é impossível de registrar, por isso selecionamos, escolhemos aquelas que desejamos nomear como 
imagens mais significativas. A fotografia que apresento neste capítulo, entre as muitas imagens que guardo e volto a olhar constantemente, é registro pessoal, em 1998. Um momento em que ao fazer o percurso de um barco de transporte de passageiros, próximo de Belém, encontrei, sobre palafitas num igarapé, uma escola. A "Escola de Primeiro Grau Graças a Deus" surpreendeu-me no meio das águas e da mata amazônica, surpreendeu-me estar aberta, portas e janelas sem trancas. Vazia, em pleno silêncio, repleta de sentidos. A experiência do lugar, escola e mata, no âmbito pessoal, foi transformadora.

A imagem que registrei no interior da escola, de apenas duas salas, tornou-se objeto de constante apreciação. Conscientização de uma realidade. É uma das imagens que tenho, junto a outras que me são significativas. O objetivo não se encontra em dizer a imagem ou a experiência vivenciada. A intenção é introduzir o que determina as questões desta pesquisa: as imagens apresentadas nas aulas de arte. Se escola, ensino, estrutura são temas que ficam evidentes ao primeiro olhar, discussões em torno de temas como hegemonia, contexto e saberes ampliam, e tornam inesgotáveis, os sentidos para esta fotografia.

Pequenos postais, desenhos e reproduções de obras também ocupam o mesmo espaço, são as minhas imagens. Questionarei no processo de pesquisa, além das perguntas inicialmente apresentadas:

Quais são as imagens com que convivem os professores de arte pertencentes ao campo de investigação?

Como estas imagens interferem ou não nos processos de ensino?

As perguntas referem-se a imagens, o texto apresentado também fará alusão a elas, porém é importante considerar que as imagens neste trabalho fazem parte de uma representação de conteúdo, não serão ilustração da literatura. Ressalto um modo de ver em que as imagens apresentadas compõem a investigação, afastando o olhar de concepções triviais no ensino de arte, sobre um tema que vem sendo bastante explorado. A pesquisa baseada também nas imagens torna- 
se uma forma de pesquisa apropriada para tempos pós-modernos. E ainda, as estratégias textuais fundamentadas nas imagens correspondem a uma escolha pessoal, um singular modo de ver e de dar a ver o ensino de arte. É conhecer as experiências de professores de arte por uma leitura, não de relatos e textos explicativos, mas por uma representação visual correspondente aos meios da arte. São ensaios puramente visuais, pensados para suscitar tantas perguntas quanto os ensaios verbais. Uma sucessão de fotografias, obtidas durante o processo de entrevistas e observação de aulas, compõe este ensaio visual. Uma sucessão de fotografias e a amplitude de olhar dirigido a elas são a própria tese.

As fotografias, inicialmente, tiveram a função de registro de pesquisa, porém durante o processo de observação e análise dos dados obtidos alcançaram uma significação de análise e resultado de pesquisa. Ao interferir nas fotografias, destacando cores no preto-e-branco, fazendo recortes para realçar detalhes ou ações, criou-se um texto visual para a pesquisa. As fotografias são aqui mostradas como uma forma de tomada de consciência, e conscientemente, uma forma de reescrever procedimentos de ensino de arte e pesquisa em ensino de arte. Assim, incluindo conteúdo, forma e contexto, em conjunto, acredito estar fornecendo novas perspectivas para observar e interpretar as ações educativas em arte.

Novas perspectivas em pesquisa educacional estão orientadas para ações de investigação e estudos com base em produções artísticas. Destacam-se neste campo as publicações mais recentes de Elliot Eisner, Ricardo Marin e Patrick Diamond. Arts Based Educational Research - ABER é um modo de pesquisa que vem se desenvolvendo no âmbito da pesquisa qualitativa.

As imagens, desde a invenção da fotografia, são utilizadas nas pesquisas da área de ciências humanas, principalmente na sociologia e antropologia. "A sociologia visual, a antropologia visual e a etnografia visual são as disciplinas que utilizam sistemática e preponderantemente a fotografia, o cinema e o vídeo para investigar a vida social e as culturas" (Marin, 2005:235). Nos debates 
metodológicos sobre a pesquisa com base em imagens há um contínuo enfrentamento entre linguagem verbal e linguagem visual. Em geral as imagens são aceitas como meio para registrar dados ou como ilustração subordinada à narrativa central.

Desde o inicio da década de 1990 a investigação baseada nas artes está tendo um importante desenvolvimento com o propósito de explorar formas alternativas de investigação, de apresentação e de representação de dados. Barone e Eisner, em publicação ${ }^{2}$, afirmam que pesquisadores estão experimentando formas de arte como modos alternativos de representar dados pesquisados. Incluem formas lingüísticas: construção de narrativas e contar histórias; e formas não-linguísticas de pesquisa: pintura, fotografia, colagem, música, vídeo, escultura, filme e até dança. Segundo Eisner, modos não lingüísticos podem apresentar a grande mudança para aqueles pesquisadores tradicionais para quem a palavra escrita tem sido a única forma de enunciar os achados de pesquisa.

As pesquisas segundo a tendência Arts-Based Educational Research se apresentam em formato menos tradicional. Utilizam linguagens que podem ser caracterizadas como: evocativa - emprega o uso de metáforas e convida o leitor a preencher aberturas no texto com significados pessoais; contextualizada emprega um tipo de descrição e observação próxima da priorizada pelos etnógrafos; é uma linguagem diretamente associada à experiências vivas; vernacular - emprega o uso de linguagem comum, cotidiana, que atrai diferentes leitores. As qualidades estéticas - formato e linguagem - não são meramente ornamentais, decorativas, representam elementos que são cuidadosamente selecionados e organizados que servem ao propósito de pesquisa.

\footnotetext{
${ }^{2} \mathrm{O}$ artigo Arts-based educacional research. In: Complementary methods for research in education. Washington,DC: American Educational Research Association, foi divulgado e obtido no site: www.fundarte.rs.gov em setembro de 2008.
} 
Há uma variedade de abordagens e procedimentos para produzir um tipo de pesquisa baseada nas artes. Ricardo Marin (2005) descreve alguns exemplos de pesquisas onde a investigação é realizada através da escrita de novelas e contos, através da música e através da fotografia. Neste último exemplo, relata a pesquisa das professoras lona Cruickshank e Rachel Mason desenvolvida entre Brasil e Inglaterra, em 1995. No Brasil este trabalho tornou-se conhecido através da pesquisa de Ivone Mendes Richter publicada em 2003 com o título Interculturalidade e estética do cotidiano no ensino das artes visuais.

Outros exemplos de pesquisas com base em estratégias textuais e visuais são relatados no título $O$ educador pós-moderno - estudo com base nas artes e no aperfeiçoamento dos professores, de Patrick Diamond e Carol Mullen. Estes autores desenvolvem o que os pioneiros Elliot Eisner e Barone defenderam na utilização de gêneros de pesquisa artística. Em suas pesquisas sobre formação docente, empregam atividades artísticas afirmando que "as representações artísticas têm o potencial de penetrarem através dos limites do conhecimento consciente para se expressarem mesmo para além daquilo que o seu criador pretendia dizer" (Diamond e Mullen, 2004:75). E ainda:

De maneira mais positiva, os investigadores artísticos procuram utilizações da linguagem que são evocativas, metafóricas, figurativas, conotativas, poéticas e divertidas. Fazendo experiências com a forma artística, aprendem sobre si mesmos e sobre as suas capacidades mais profundas à medida que lidam com os caminhos de fuga ou os becos sem saída dos outros (Idem:77).

$\mathrm{Na}$ perspectiva de Hernandèz (2008) a pesquisa com base nas artes mediante procedimentos artísticos (visuais, literários, performativos e musicais) está em equilíbrio com o propósito investigador de toda atividade artística. Hernandèz também apresenta exemplos de pesquisas realizadas onde a imagem é substância e objeto de pesquisa.

Com a intenção de justificar e apresentar algumas das fotografias produzidas nesta tese, tomei inicialmente imagens bastante significativas do meu repertório. 
Recorri a referências atuais que fundamentam o uso de textos visuais em pesquisas. Reconheço que fotografia e texto interconectados um com o outro produzem novos e relevantes significados. Conforme afirma Rita Irwin, a interconexão entre imagens e textos não são "discursos que se colocam um sobre o outro, transferindo significado de um campo textual a outro, mas são interconexões que falam em conversações com, em e através da arte e do texto, de tal maneira que esses encontros são constitutivos mais que descritivos" (Irwin apud Hernandèz, 2008:14).

Apresento, então, as professoras em instantes de aula. Se a imobilidade da foto nos leva a mencionar que isso aconteceu e não acontece mais, é passado, a minha presença naquele instante o torna eterno, vi e fotografei. As fotografias mostram que estive lá, são certificados de presença em uma aula de arte, uma presença imediata no mundo que congela instantes para transformá-los em reflexões e pesquisa. 
1.1. Instantâneos de professoras de arte

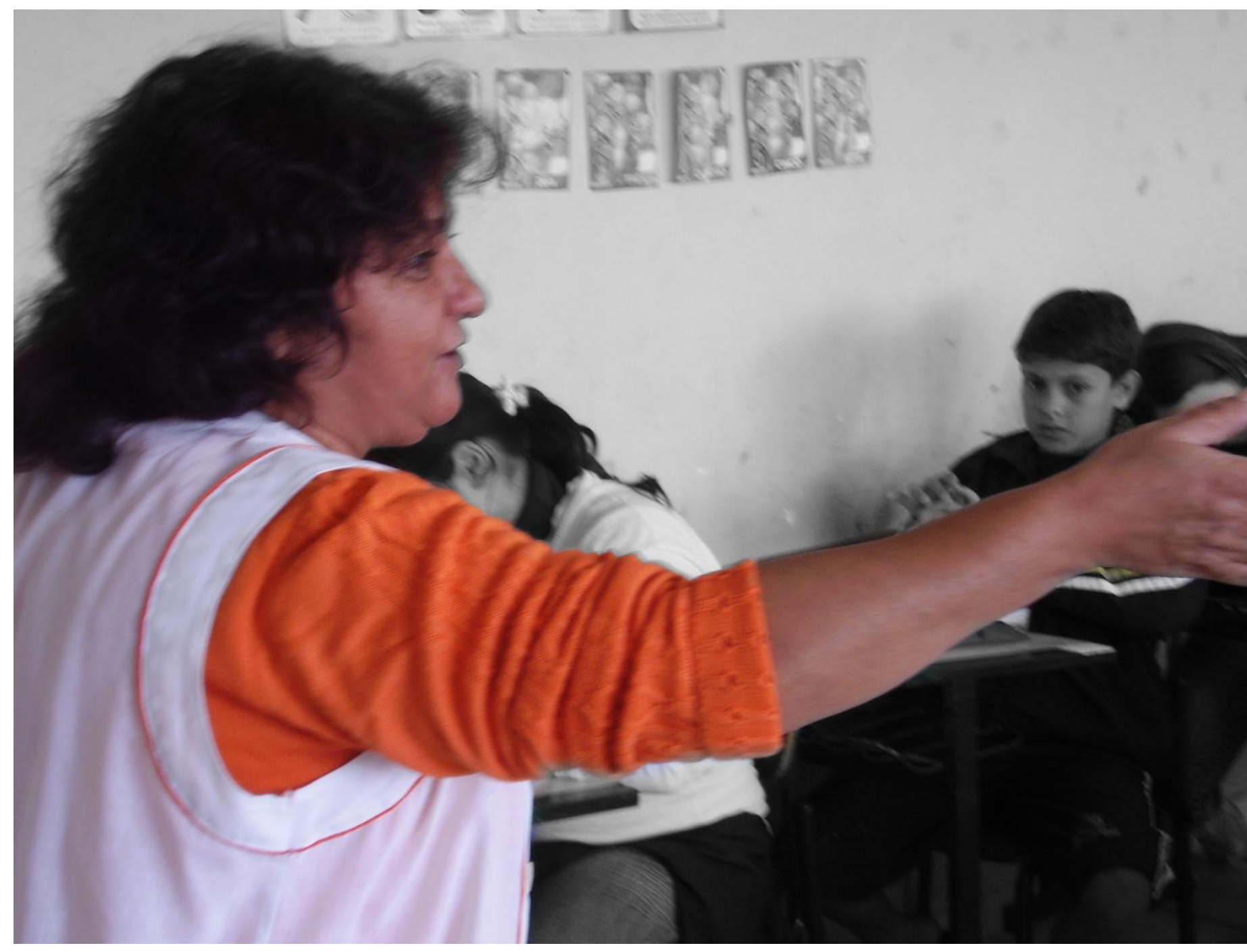

Em pé na sala de aula, a professora está com a mão estendida num gesto típico, explicando, expondo conteúdos. Professora BN. 46 anos. Identifica-se nesta pesquisa com o pseudônimo Frida Khalo. Atua na área de ensino de arte há 16 anos, com 40 horas semanais. Trabalha nos turnos matutino, vespertino e noturno, no Centro Educacional Municipal Araucária. O olhar do menino vai para quem fotografa. Na parede, trabalhos de aulas anteriores.

Centro Educacional Municipal Araucária

Fundado em 2002

Rua Alaésio Ildefonso da Rosa, s/nํ- Bairro Jardim Araucária - Serraria

São José - Santa Catarina 


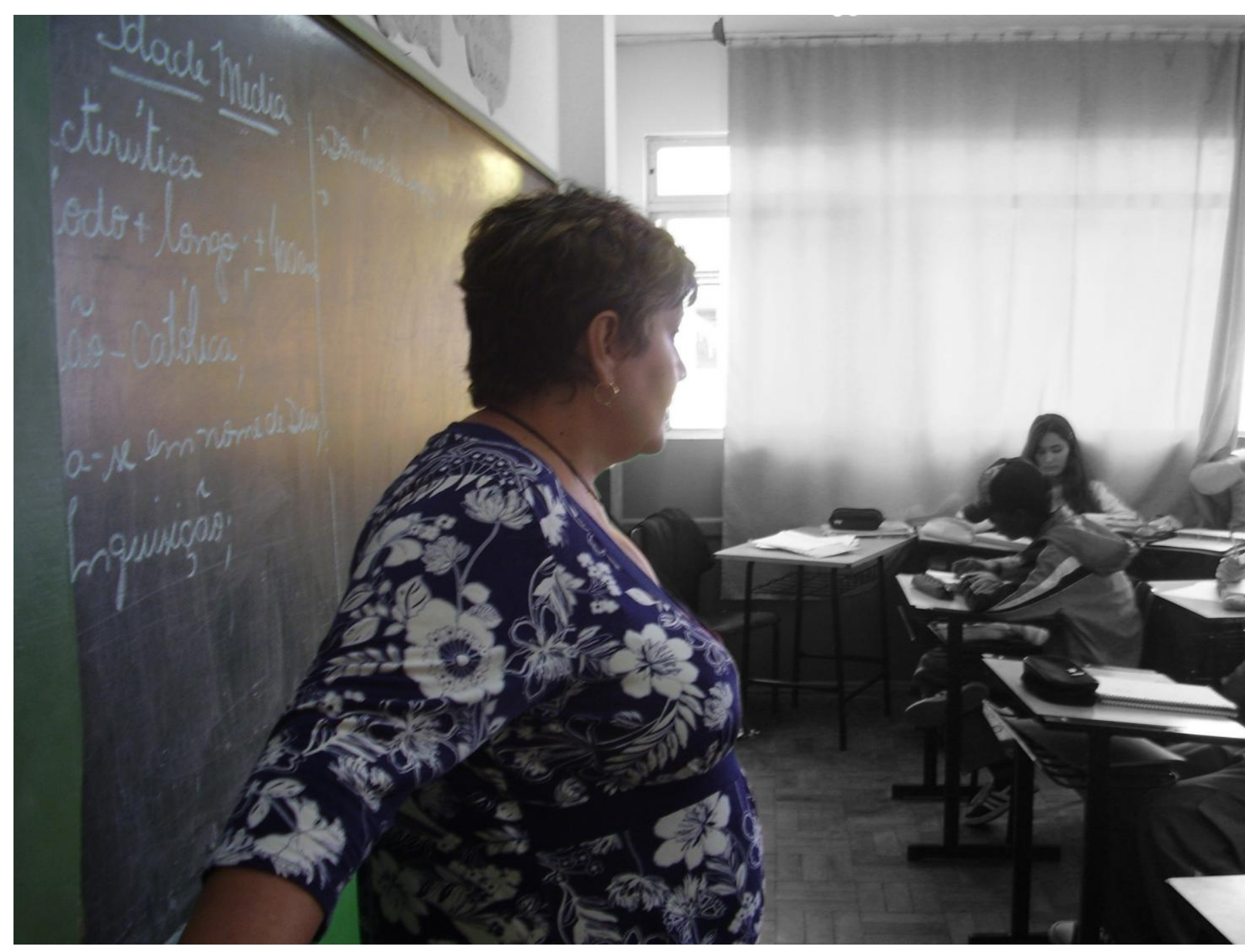

Em frente ao quadro, a professora fala com os alunos; referem-se ao conteúdo escrito, características, período e fatos sobre a Idade Média. Professora AC. 47 anos. Identificase nesta pesquisa com o pseudônimo Kandinsky. Atua na área de ensino de arte há 28 anos, com 40 horas semanais. Trabalha nos turnos matutino e noturno, no Colégio Municipal Maria Luiza de Melo, no bairro Kobrasol, em São José.

Os alunos adolescentes sentam-se individualmente em carteiras alinhadas.

Colégio Municipal Maria Luiza de Melo

Fundado em 1988

Rua José Fermínio Novaes, s/no - Bairro Kobrasol

São José - Santa Catarina 


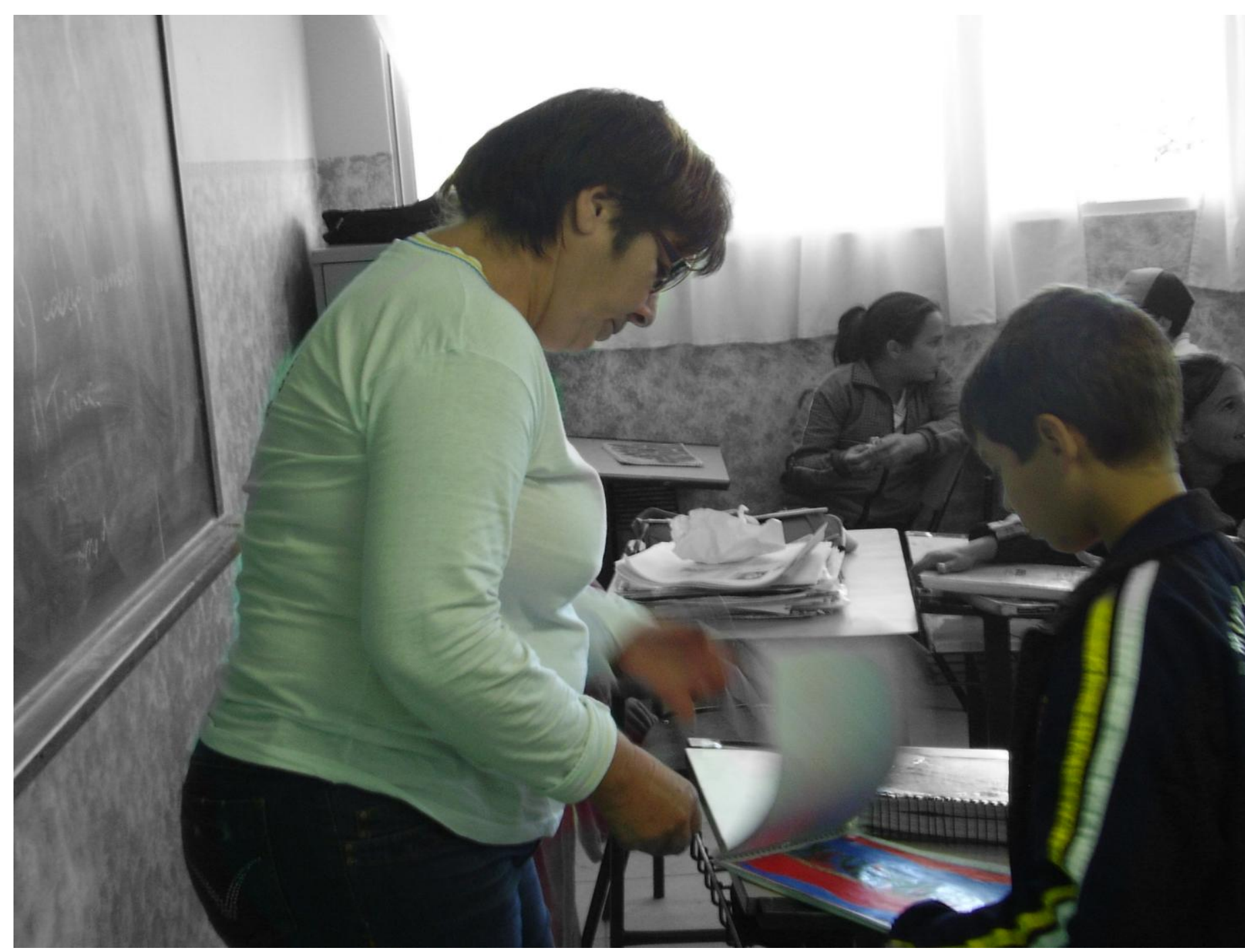

Em frente ao quadro, a professora atende um aluno, observa o caderno, destacando a boa qualidade do colorido que o menino faz em seus desenhos. Professora ET. 48 anos. Identifica-se nesta pesquisa com o pseudônimo Tarsila. Atua na área de ensino de arte há 20 anos, com 40 horas semanais. Trabalha nos turnos matutino e noturno, no Centro Educacional Municipal Governador Vilson Kleinubing, no loteamento Lisboa. Os alunos conversam entre si.

Centro Educacional Municipal Vilson Kleinubing

Fundado em 1999

Rua Geral do Loteamento Lisboa, quadra 5, s/no - Bairro Forquilhas

São José - Santa Catarina 


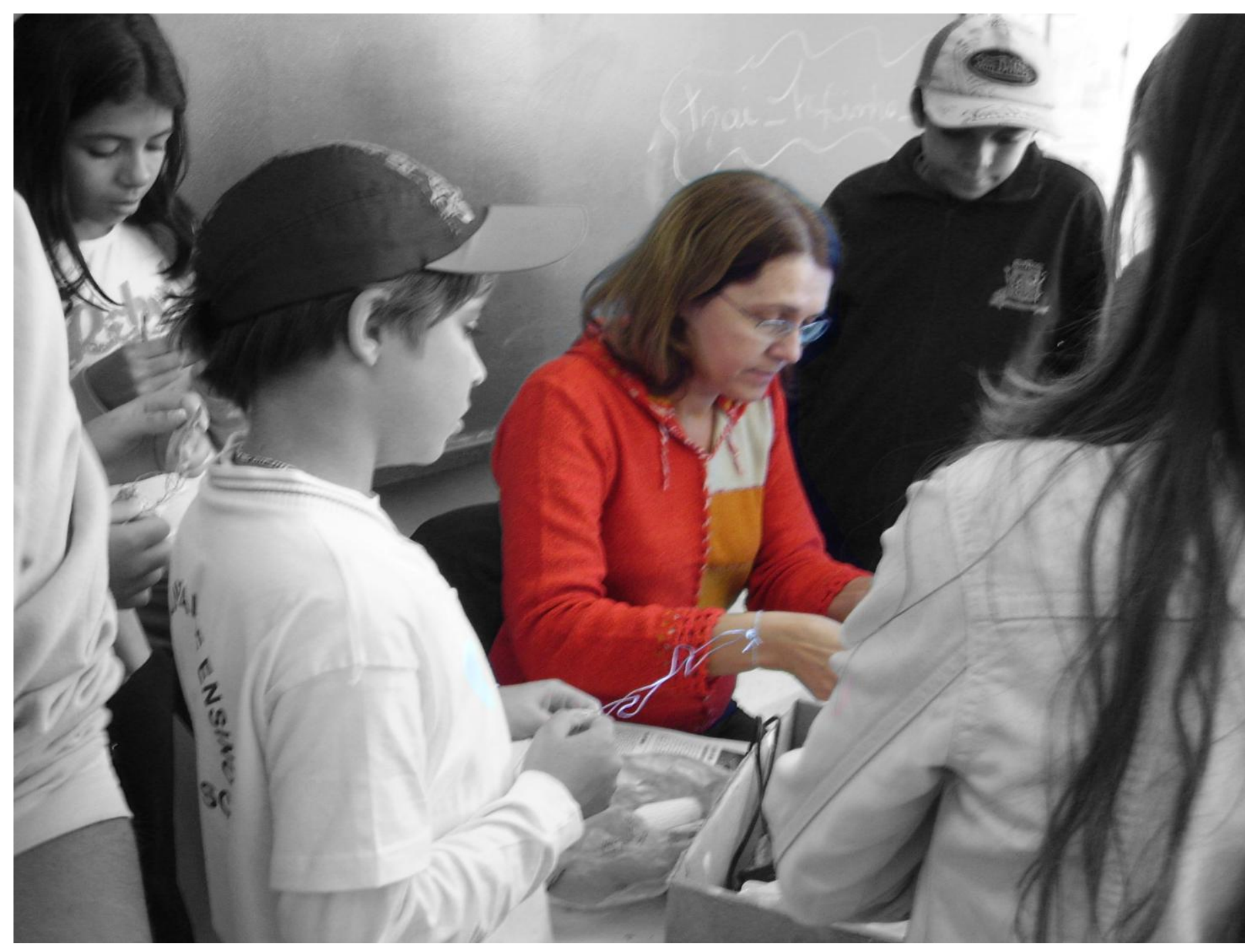

Sentada, com os alunos ao seu redor, a professora realiza um trabalho com arame e gaze gessada. Professora DB. 48 anos. Identifica-se nesta pesquisa com o pseudônimo Vincent van Gogh. Atua na área de ensino de arte há 23 anos, com 40 horas semanais. Trabalha nos turnos matutino, vespertino e noturno, no Centro Educacional Municipal Antônio Francisco Machado, no bairro Forquilhinhas. Os alunos observam a professora umedecer a gaze gessada num pequeno pote plástico e aguardam sua vez de cobrir a estrutura de arame.

Centro Educacional Municipal Antônio Francisco Machado

Fundado em 2003

Rua Osvaldo Cruz, s/no - Bairro Forquilhinhas

São José - Santa Catarina 


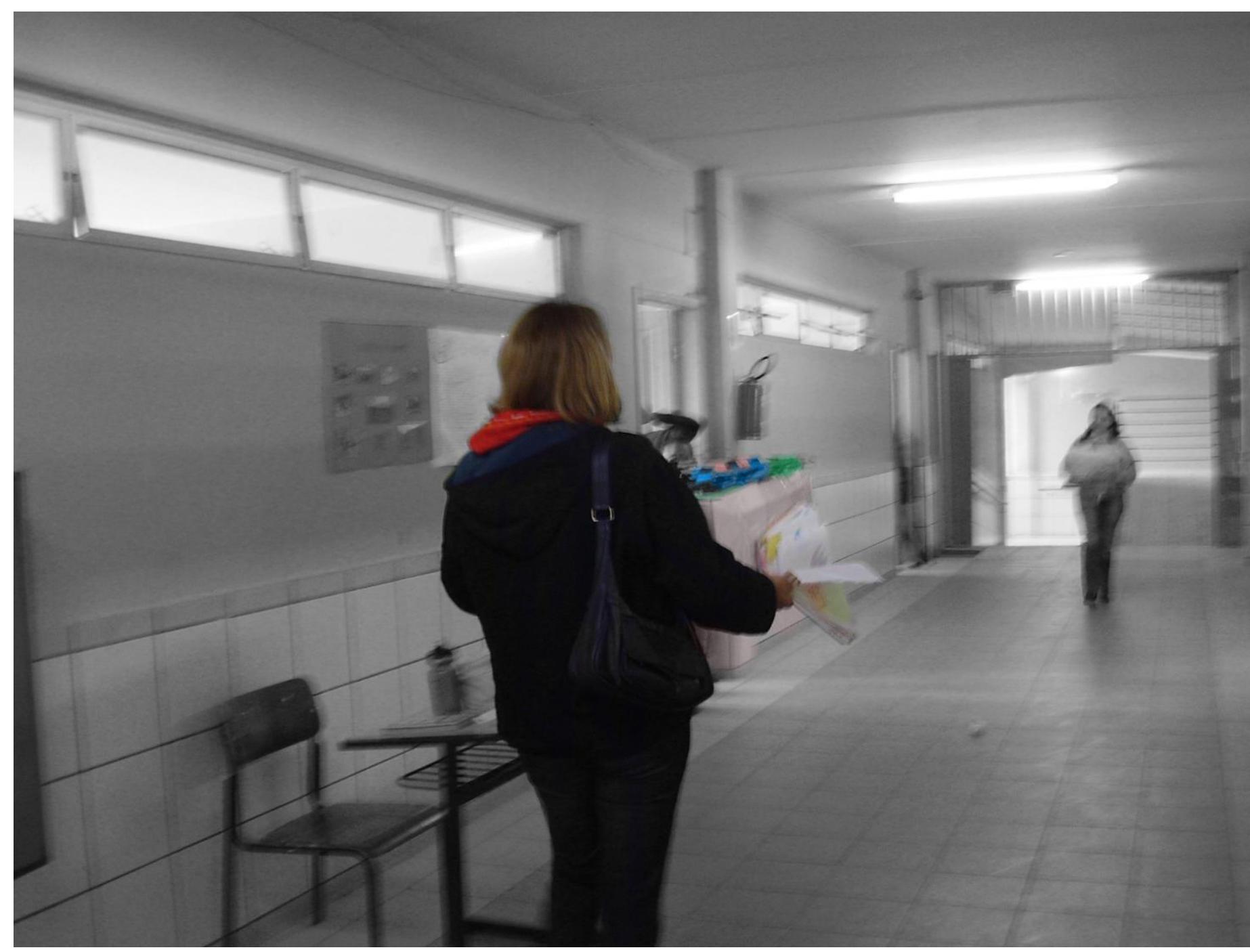

Professora DB caminha de uma sala para outra levando uma grande caixa com materiais para a próxima aula; as produções da aula que terminou vão sobre a tampa da caixa, papéis com desenhos numa das mãos, bolsa no ombro.

Centro Educacional Municipal Antônio Francisco Machado

Fundado em 2003

Rua Osvaldo Cruz, s/no - Bairro Forquilhinhas

São José - Santa Catarina 


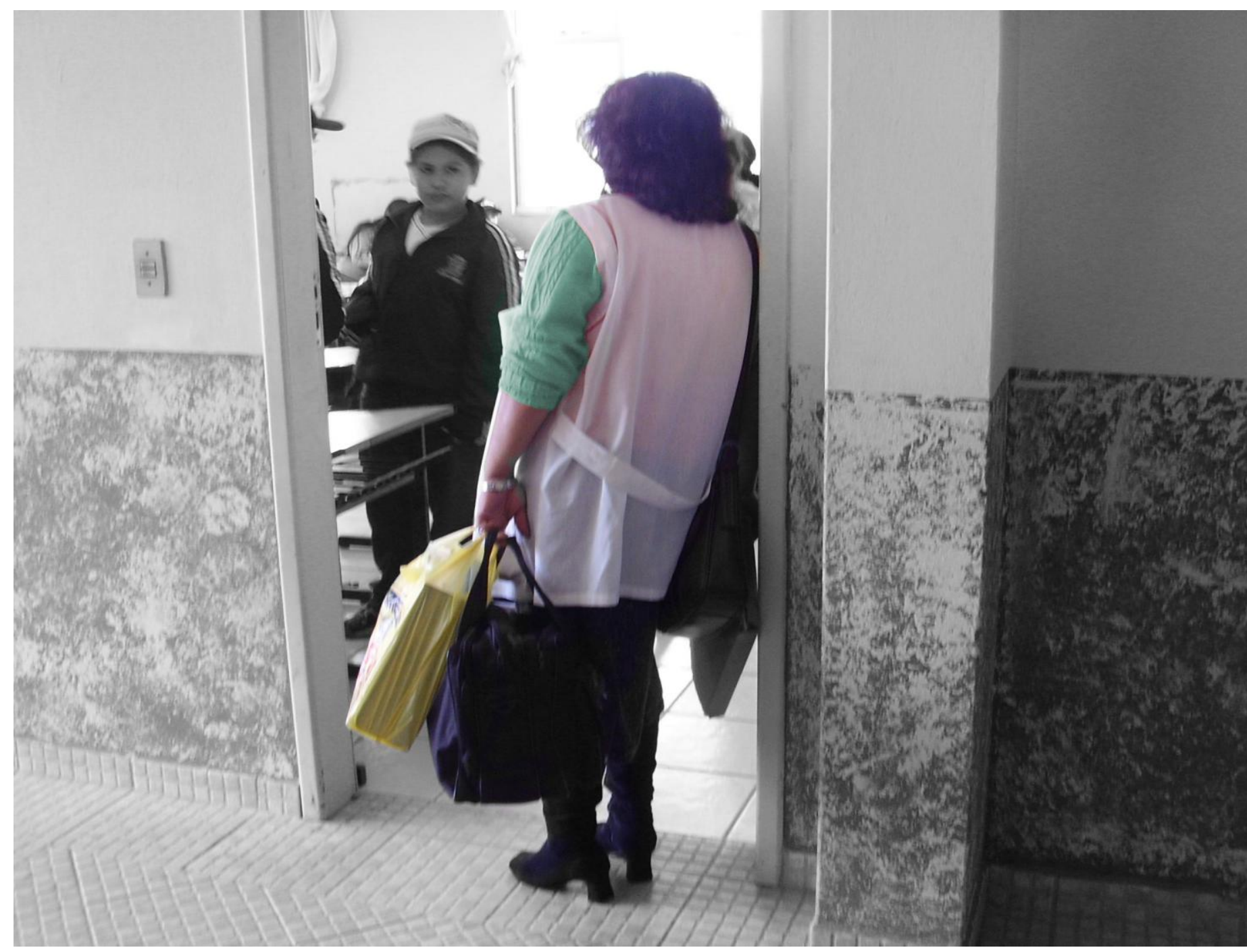

Professora BN espera para entrar na sala de aula. De sala em sala leva sacolas com material para uso dos alunos, materiais didáticos, bolsa e pasta com diário de classe e cadernos.

Centro Educacional Municipal Araucária

Fundado em 2002

Rua Alaésio Ildefonso da Rosa, s/no - Bairro Jardim Araucária - Serraria

São José - Santa Catarina 


\subsection{Recortes do ensino de arte}

O ensino de arte no Brasil vem sendo abordado por pesquisadores em seus múltiplos e complexos aspectos. Destaco Ana Mae Barbosa que, desde sua publicação em 1978, tanto registrou o histórico dessa trajetória quanto vem acompanhando o desenvolvimento de experiências, práticas e pesquisas, escrevendo permanentemente a história contemporânea do ensino de arte. ${ }^{3}$ Mesmo que tenhamos outros pesquisadores no nosso país, desde a Lei 5.692/71 referências a Ana Mae são constantes. Com a obrigatoriedade instituída pela Lei de Diretrizes e Bases da Educação, em 1971, o ensino de arte nas escolas gerou conflitos conceituais sobre teoria e prática, sobre a organização do ensino polivalente ou interdisciplinar, sobre processo e produto, sobre propostas metodológicas, conteúdos, avaliação e objetivos. Idéias como livre-expressão e desenvolvimento da criatividade foram exploradas em diversas situações de ensino, ou seria melhor, em diversas situações de estímulo à atividade artística criadora.

A arte-educação ${ }^{4}$ foi sustentada, durante muito tempo, pelo objetivo de desenvolvimento pessoal criativo através da produção artística. As atividades nutriam-se da expressão individual e originalidade; o fazer artístico era fundamentado por uma orientação pedagógica de livre-expressão. Pesquisas realizadas no período inicial de 1971 a 1973, conforme apresenta Ana Mae Barbosa $^{5}$, confirmavam esta prática, porém já admitiam que um dos papéis da arte

\footnotetext{
3 Referência aos títulos de Ana Mae Barbosa. BARBOSA, Ana Mae (org). Arte/educação contemporânea: consonâncias internacionais. São Paulo: Cortez, 2005.(org.) Inquietações e mudanças no ensino da arte. São Paulo: Cortez, 2002.Tópicos utópicos. Belo Horizonte: C/Arte, 1998.(org) Arte-educação: leitura no subsolo. São Paulo: Cortez, 1997.(org). O ensino das artes nas universidades. São Paulo: EDUSP: CNPq, 1993. A imagem no ensino da arte. São Paulo: Perspectiva:1991. Arte-Educação: conflitos e acertos. São Paulo: Max Limonad, 1984. Recorte e colagem: influência de John Dewey no ensino de arte no Brasil. São Paulo: Cortez, 1982. Teoria e prática da Educação Artística, São Paulo: Cultrix, 1982. Arte-educação no Brasil: das origens ao modernismo. São Paulo: Perspectiva:1978.

${ }^{4}$ Reconheço a atualidade do uso do termo ensino de arte, porém a nomenclatura arte-educação é aqui usada por ser a denominação utilizada no contexto a que faço referência.

${ }^{5}$ Cf. Ana Mae Barbosa, Teoria e prática da Educação Artística, São Paulo: Cultrix, 1982.
} 
na educação é a preparação para novos modos de percepção, e defendiam: "O professor deve ensinar a ver, a analisar, a especular." Ou ainda: "A idéia é não desestimular a criança, já estimulada pelos media, mas fazê-la refletir sobre a imagem" (Barbosa, 1982:71,92).

Nesse período, entre "conflitos e acertos", tendo Arte-educação como movimento que muito produziu e advogou em favor da área, e Educação Artística como disciplina instituída, caminhamos em direção ao ensino de Arte. As pesquisas realizadas e suas publicações, assim como a divulgação e discussão em congressos e seminários, contribuíram para conquistar a arte como disciplina e área de conhecimento. O preconceito contra a arte do adulto foi vencido - não sem muita contestação - nas atividades escolares. Na educação e no ensino, recuperamos a obra de arte, suas reproduções e outras imagens. No debate conceitual introduziram-se as temáticas do multiculturalismo, teorias metodológicas, interpretação de obras. Esta última, extremamente necessária para a significação dos termos leitura e contextualização ${ }^{6}$. A temática de interpretação ou leitura, naquela ocasião, apresentou-se como novo conceito para muitos professores do ensino fundamental.

Se o aumento dos debates e inovações foi provocador para uma melhoria do ensino, por outro lado algumas problemáticas se apresentaram. Leitura confundida com descrição de imagem, apreciação confundida com bel-prazer, contextualização confundida com história e, então, naquele momento, produção confundida com cópia. $\mathrm{O}$ trabalho e empenho de pesquisadores tem sido amplo para desfazer tais equívocos. O fato mais evidente é que a cada ação, em diferentes tempos - leia-se Lei 5692/71, LDB 9394/96, Parâmetros Curriculares Nacionais, em 1998 - avanços se concretizam, entretanto com eles novas problemáticas se apresentam.

\footnotetext{
${ }^{6}$ Excluo aqui os termos fazer e produção, bastante divulgados através da Proposta Triangular, de Ana Mae Barbosa, e posteriormente através dos Parâmetros Curriculares Nacionais, por terem sido sempre considerados, como atividade artística, inerentes à aula de arte.
} 
No caso dos Parâmetros Curriculares Nacionais - PCNs Arte, a liberdade gerada para a determinação de conteúdos e procedimentos de ensino propiciou aos professores de arte uma abertura para escolhas. Entretanto, escolher o quê? Quais conteúdos? Quais procedimentos? Quais imagens? Para uma possível abertura a escolhas, seria necessário anteceder uma ação de fomentar conhecimento em arte, aliada à formação de professores capazes de ler, produzir e escolher imagens. Sobre esta discussão, Ana Mae Barbosa (2002:14) afirma:

Leis tão pouco garantem um ensino/aprendizagem que torne os estudantes aptos para entender a Arte ou a imagem na condição pós-moderna contemporânea.(...) Somente a ação inteligente e empática do professor pode tornar a Arte ingrediente essencial para favorecer o crescimento individual e o comportamento de cidadão como fruidor de cultura e conhecedor da construção de sua própria nação.

Para nós, professores, nossa ação é realmente relevante quando alcança preparar os alunos para a relação com a arte. Esta preparação, constituída de contínua ação de ensino, nos termos de Ana Mae, "inteligente e empática", é encaminhada por distintas e singulares escolhas dos professores. As escolhas são da ordem dos conteúdos, dos objetivos, dos procedimentos e fundamentos metodológicos. As escolhas são da natureza da arte, da materialidade, da experiência, dos conceitos, das imagens.

As imagens da arte são a apresentação da arte, a representação da arte ou o próprio objeto de estudo em arte. Este é, talvez, um dos aspectos mais importantes no contexto do ensino da arte: a escolha das imagens; e, paradoxalmente, muitas vezes não nos lembramos o quanto as imagens apresentadas aos alunos podem intervir na construção do seu conceito de arte. Assim sendo, minha escolha, neste estudo, são as escolhas das professoras ${ }^{7}$. Pesquisas têm sido desenvolvidas em diversas esferas do ensino de arte - novas tecnologias, ação social, multiculturalismo, gênero, teorias metodológicas, históricas, interpretação, cognição. Entre a diversidade de pesquisas

\footnotetext{
${ }^{7}$ Em todo o texto tratarei sempre a titulação da profissão por 'professoras', a opção deve-se por
} terem participado da pesquisa somente mulheres professoras de arte. 
encaminhadas nesta área, tomo a imagem como "matéria-prima"8. Dito mais precisamente, imagens que apresentam a arte contemporânea estão presentes na aula de arte? Quais imagens as professoras, em sua singularidade, escolhem para apresentar aos seus alunos como arte?

É importante reconhecer que as imagens que circulam no meio escolar através de publicações, materiais de apoio ao professor e outros recursos já são anteriormente escolhidas por produtores, mídia e indústria cultural. Até mesmo a curadoria de exposições já seleciona o que será visto, em que ordem, sob qual critério. A preponderância de imagens produzidas para uso dos professores de arte será determinante dos projetos de ensino? Acredito que esta pesquisa poderá perturbar, nos termos de Foucault ${ }^{9}$, nossas empíricas classificações, pois nem todos os materiais de apoio ao professor, com reproduções em alta qualidade e larga distribuição, chegam às mãos daqueles que não fazem parte de projetos específicos ou que estão distantes dos grandes centros culturais.

Sabemos que uma tese acadêmica precisa ter seu recorte bem definido, seu objeto de estudo bem delimitado e com esta preocupação nasce este trabalho. Este estudo dirige seu foco para professoras de arte, mais especificamente para as imagens que as professoras de artes visuais incluem em seus projetos de ensino. Identificaremos se imagens de obras da contemporaneidade são incluídas pelas professoras de artes visuais em seus projetos de ensino. A formação de professores vem sendo estudada em seus períodos de formação inicial ${ }^{10}$ graduação - e formação contínua ${ }^{11}$ - vida profissional. O que aqui se vai pensar, entre outras premissas, é que a formação do professor de arte não se restringe ao período no qual ele se ocupa, dentro de uma Universidade, de obter o direito de exercer a profissão, mediante o cumprimento de um currículo e a obtenção de um diploma. Isto porque se vai propor a idéia de que, em se tratando do fenômeno

\footnotetext{
${ }^{8}$ Cf. Ana Mae Barbosa, "Pesquisas em ArteEducação: recorte sociopolítico" in: Educação e Realidade. Dossiê Arte e Educação. Arte, criação e aprendizagem. Porto Alegre: UFRGS, 2005.

${ }^{9}$ Ref. Michel Foucault, As palavras e as coisas. São Paulo: Martins Fontes, 1999.

${ }^{10}$ Cf. Selma Garrido Pimenta, Estágio e docência. São Paulo: Cortez, 2004.

${ }^{11}$ Idem.
} 
visual, em seu sentido amplo, as vivências iniciam e se consolidam em noções, idéias e princípios muito antes de o sujeito ingressar em uma graduação - até em decorrência dessas mesmas experiências é que ele procura um curso de Arte.

A história de vida dos educadores tem sido pesquisada para compreender suas práticas. Suas experiências de vida e formação têm sido estudadas por pesquisadores através da abordagem biográfica como metodologia, escritas de si e narrativas de história de vida. Entre os pesquisadores desta área destaco Antonio Nòvoa ${ }^{12}$ (1992:17), autor que afirma:

Aqui estamos. Nós e a profissão. E as opções que cada um de nós tem de fazer como professor, as quais cruzam a nossa maneira de ser com a nossa maneira de ensinar e desvendam nossa maneira de ensinar na nossa maneira de ser. É impossível separar o 'eu' profissional do 'eu' pessoal.

Do mesmo modo que as experiências pregressas à formação inicial, em relação à visualidade, interferem no universo de imagens que o professor considera como Arte, igualmente as experiências posteriores também continuam interferindo. Como exemplo, há a própria contemporaneidade: os professores graduados há muito tempo não tiveram, em seu currículo, os rumos da arte contemporânea. Simplesmente porque estes rumos ainda não haviam sido esboçados. Para uma disciplina cujo objeto de estudo é a Arte, a formação dos professores é contínua e permanente, independentemente do fato de estarem fazendo cursos de atualização. Ela se dá pelo contato, pela "familiaridade", pela "freqüentação" das imagens das ruas, da televisão, das vitrines, das revistas, dos livros e, com menor freqüência, imagens dos museus, galerias e instituições culturais quando esse professor mora longe dos grandes centros. E esta é a realidade da maior parte dos professores de arte no Brasil. Um problema para o professor é que, inclusive, novas imagens vão se apresentando. $O$ apelo à atualização do professor deve ser grande. O foco do ensino, na sua formação, deve ser desenvolver a capacidade de análise destes professores em relação ao

\footnotetext{
${ }^{12}$ NÒVOA, António. Profissão professor. Portugal: Porto Editora,1995. Vidas de professores. Portugal: Porto Editora, 1992. Os professores e sua formação. Lisboa: Dom Quixote,1992.
} 
que vêem, não só o repertório em artes visuais, porque quando se desenvolve um repertório tem-se que apelar para a idéia de que um repertório nunca está completo. Há a necessidade de atualização constante.

Assim, entre muitos autores que tratam da arte, da contemporaneidade e educação, busco um diálogo - além dos diálogos com as professoras - com aqueles que têm sido referência em minha formação. Dois brasileiros, pernambucanos, que com suas ações provocaram um processo de conscientização em minha relação com arte e educação: Ana Mae Barbosa e Paulo Freire. Com eles aprendi a unidade entre ação e reflexão, a eles devo um entendimento e vivência daquilo que se chama praxis. Ambos sustentam as ações desta pesquisa. Ana Mae Barbosa por ter aberto caminhos, por ter sido organizadora e incentivadora da área de Arte-educação. Paulo Freire por ter realizado o que se dizia utopia. Entre as propostas desenvolvidas por estes autores, destaca-se neste trabalho o conceito, acredito comum a ambos, de leitura.

Leitura de imagens, em Ana Mae, e leitura de mundo, em Paulo Freire, são saberes e práticas de relações dialógicas onde a existência se faz humana, onde conscientemente apropria-se de uma realidade e inseridos nela podemos "ser mais". "Pensar-se a si mesmos e ao mundo, simultaneamente" (Freire, 1987:72) e "provocar o diálogo entre obra e espectador, em qualquer fase de intimidade com a imagem em que ele esteja, suscitando olhares imprevistos, buscando despertar nos sujeitos um desejo de aprofundar os conhecimentos quanto à arte" (Barbosa, 2005:212) são princípios desta pesquisa.

Considerando que o objeto de estudo da Arte é a Arte e o que for apresentado como Arte; considerando também que se o que for apresentado concretizar-se na forma de imagens, o que se acredita como mais significativo e que fica gravado na memória, qual a dimensão de um nome para uma disciplina no currículo escolar? O que ensina o professor de arte? Arte? O que ensina o professor de geografia? 
Geografia? E o professor de português? Português? Geografia significa ensinar a perceber a realidade do lugar onde vivemos, do país, do mundo, a natureza e seus fenômenos, a organização do espaço, a vivência humana neste planeta. Em português, o ensino-aprendizagem aborda produção de textos, gramática, leitura, expressão oral e escrita. Em arte, o que é apresentado com este nome? Qual a diversidade dos conteúdos e fundamentos da disciplina? E o que "ilustra" estes conteúdos e fundamentos?

As nomeações que ao longo da história foram sendo atribuídas à Arte no contexto escolar são exemplos do que foi afirmado anteriormente. Educação através da arte e Arte-educação representam movimentos com bases epistemológicas para uma reciprocidade entre arte e educação; Educação artística e Arte, nomenclaturas oficiais desde sua implantação como disciplina escolar, denominam a proposta educacional e a qualidade da presença da arte como componente curricular. As palavras utilizadas, o nome que se dá às coisas em geral, deixam implícito o conceito, a idéia, a imagem que se tem dessas coisas. Temos uma problemática: os alunos aprendem como arte aquilo que o professor apresenta como arte.

Pode-se afirmar que apresentar é dar nome, é escolher palavra que represente algo ou alguém. "Quando Platão define o nome como 'instrumento apto a ensinar e fazer discernir a essência, do mesmo modo como a lançadeira está apta a tecer a tela' (Crat.,388b), sua definição adapta-se a qualquer termo ou expressão lingüística" (Abbagnano, 2000:714). Lemos também em Platão que aquilo que dá significado à palavra é o uso.

Nomear, chamar de, é exprimir qualidade característica, descritiva de uma coisa ou pessoa. O ser humano, em seu desenvolvimento e conhecimento sobre si próprio e sobre a natureza, procurou categorizar qualidades. Criou palavras. Criou classificações. Se uma das noções humanas primordiais foi operatória, mais que dar nomes, o homem desenvolveu-se classificando. No prefácio de As 
palavras e as coisas, Michel Foucault afirma que o referido livro nasceu de um texto de Jorge Luiz Borges, onde está escrito:

(...) os animais se dividem em: a) pertencentes ao imperador, b) embalsamados, c) domesticados, d) leitões, e) sereia, f) fabulosos, g) cães em liberdade, h) incluídos na presente classificação, i) que se agitam como loucos, j) inumeráveis, k) desenhados com um pincel muito fino de pêlo de camelo, I) et cetera, $m$ ) que acabam de quebrar a bilha, n) que de longe parecem moscas (Foucault ,1999: pref.).

Esta classificação, segundo Foucault, que "perturba todas as familiaridades do pensamento", nos leva a refletir sobre as categorias e hierarquias que podem ser reordenadas. Quero então destacar que em situações de ensino, quando o professor com seu reconhecido status de professar ou autoridade de conhecedor da área afirmar: "isto é arte"; ou "esta imagem representa um objeto de arte"; ou "esta imagem não é arte", estará determinando não apenas inclusões e exclusões no repertório de seu aluno, mas criando categorias e, ainda, atitudes que poderão restringir a atitude reflexiva que a arte contemporânea propõe.

Pensar a importância do ato de nomear torna-se fundamental nos processos de ensino que abordam a pluralidade da arte contemporânea. Ao expandir suas possibilidades a arte gerou uma disseminação de propostas, nem sempre acompanhadas pelas propostas de ensino, tanto no campo da criação quanto no da reflexão. Ao assumir uma pluralidade de meios e poéticas, a arte colocou em questão não só os suportes e categorias tradicionais, mas também a história da arte, que deixa de ser caracterizada por um desenvolvimento linear e, com ela, os conceitos que a embasavam. Cada obra passa a definir seus critérios próprios, as produções sugerem como devem ser percebidas, cada obra exige diferentes aproximações. Foi o que germinou após Duchamp transformar objetos industrializados em obras, instaurando novos critérios, não mais formais e de habilidade, mas sim fundamentados nos conceitos que as originam. Até mesmo a qualificação "obra de arte" foi transformada, deixando o cavalete, o pedestal ou a 
moldura, e em decorrência dos novos critérios apresentou-se a destituição do conceito de obra.

As potencialidades múltiplas da arte contemporânea sugerem processos também múltiplos para o ensino de arte. $O$ que percebemos nas situações de ensino é que a arte de hoje está cada vez mais distante do público; mesmo que as ações educativas de museus ou projetos integrados entre artistas, museus e escolas minimizem esta problemática, para muitas pessoas ainda não se estabelece uma real comunicação entre arte, ensino e público.

Sabemos que em muitas obras os conceitos são abertos e vão muito além do campo visual. Em outras produções, aspectos formais ou de figuração estarão mais evidentes. O que determinará a escolha do professor sobre as imagens que apresentará aos seus alunos possivelmente será originado em sua história de vida, na sua formação inicial, na continuidade de sua formação, no conhecimento dos níveis de desenvolvimento da compreensão da imagem, na sua vivência em arte.

Há que se ponderar, ainda, sobre o distanciamento entre reprodução e obra. Tamanho, qualidade de cores, tratamento de superfícies, cheiros, uma simultaneidade de percepções e outros inúmeros fatores impedem uma aproximação com a realidade do objeto artístico apresentado. Quando se trata da arte contemporânea, mais aumenta a distância entre obra e suas reproduções, uma vez que, sabe-se, a arte pede a presença, viva, curiosa, aberta à experiência. Longe dos grandes centros, nada mais se pode mostrar do que reproduções, em imagens fixas ou em movimento, porém cópias e representações. O que se espera é que a partir dos resultados obtidos nesta pesquisa os professores possam refletir mais sobre suas escolhas, suas determinações e suas implicações, bem como contextualizar essas escolhas, para si mesmo e para os seus alunos, no âmbito da cultura e da arte. 


\section{REFLEXÕES SOBRE ARTE E SEU ENSINO}

\section{1. TEMPOS DA IMAGEM NO ENSINO DE ARTE}

2.1.1. Antecedentes da leitura: o ensino de arte modernista

Na prática cotidiana entre professores e alunos a arte-educação baseada em uma definição modernista valorizou aqueles mais habilidosos; as crianças eram encorajadas a ser sempre originais em seu fazer artístico - como se a leitura de imagens não contribuísse para uma significação pessoal e original -, não se enfatizando um entendimento cultural, contextualizado, produzindo sentido e conectando a produção artística à própria vida. $O$ ideal modernista de dar oportunidade aos alunos para se organizarem e se expressarem, sem imposição de modelos, livres de orientações formais, depositou sobre a criança o ponto de partida da atividade educacional. A criança foi considerada como foco central dos processos de ensino e aprendizagem, desvinculando estes processos dos conteúdos da própria arte, de um conceito central em arte. Nesse período, antecedente à introdução do termo e ações de leitura, os conteúdos da arte foram marginalizados em favor de uma arte escolar libertadora de manifestações emocionais e "ligada à expressão criadora difusa" (Barbosa, 2005:17).

"Liberdade, sensibilidade, originalidade, criatividade, naturalidade, espontaneidade, imaginação e genialidade são, por si, os conceitos-chaves da opção educativa baseada na auto-expressão" (Agirre, 2005:219). Estes princípios tão caros ao modernismo foram redentores se comparados aos métodos e pressupostos de ensino e aprendizagem da pedagogia tradicional; entretanto, em arte-educação, levaram algumas práticas pedagógicas ao extremo de permitir um entendimento de arte como nonsense. ${ }^{13}$

\footnotetext{
${ }^{13}$ Nonsense equivale a sem sentido. Termo atribuído por Ana Mae Barbosa em Arte-educação: conflitos e acertos, p.52-53, para referir-se às práticas educativas que desvinculam objetivos, métodos e conteúdos, tornando as atividades artísticas sem significação pessoal.
} 
Alguns teóricos da arte-educação atribuem ao pensamento modernista em arte-educação a idéia de arte como livre-expressão. A valorização de uma suposta virgindade expressiva infantil, característica deste pensamento modernista em arte-educação, afastou crianças, alunos das instituições de ensino, da arte do artista e de suas reproduções.

Com esta atitude impede-se o consumo da imagem de mais alta qualidade, aquela que é produzida pela arte, e mantém-se a criança imersa no mundo de imagens produzidas apenas pela indústria cultural. A inevitável mimese visual é exercida portanto sobre as histórias em quadrinhos, as ilustrações dos livros didáticos em geral de baixa qualidade estética) e principalmente, sobre as imagens da TV.

Este posicionamento caracteriza o que podemos chamar de ensino da arte modernista que concebe a arte como expressão e relação emocional, priorizando a originalidade dentre os processos mentais envolvidos na criatividade (Barbosa, 1997:10).

Entretanto, os principais teóricos modernistas em arte-educação, Herbert Read e Victor Lowenfeld, já ponderavam sobre a apreciação. A apreciação entendida em seu sentido de se assumir uma atitude estética em face de algo, atividade do espectador pura e simples, isto é, uma atitude desprendida de perceber um objeto ou julgá-lo conforme sua utilidade, valor ou moral.

Lowenfeld em seu livro Desenvolvimento da capacidade criadora, já na primeira edição, em 1947, apresenta um capítulo com o título O desenvolvimento da consciência estética, onde discute, no subtítulo Apreciação da arte, o fato de crianças reagirem diferentemente aos trabalhos artísticos segundo seus níveis de desenvolvimento, e ainda, como e por que as imagens de arte devem entrar nos projetos de ensino. Sobre o interesse pela própria arte nas atividades escolares, este autor já afirmava que

o objetivo de mostrar trabalhos de arte às crianças não é ensiná-las a analisar quadros ou a reconhecer uma obra de arte. (...) o interesse pela arte deve ser encorajado, mas não, necessariamente, no sentido da aproximação cronológica da evolução da arte moderna. (...) É necessário que esses exemplos sejam vistos como meio de incentivar a discussão e ampliar os 
possíveis caminhos de ação, mas não como exemplos a imitar (LowenfeldBrittain, 1977:396-397).

Em Herbert Read, no seu livro $A$ educação pela arte, com a primeira edição em 1963, encontra-se no capítulo $A$ forma natural de educação o item Três aspectos do ensino de arte, onde o autor apresenta atividades que correspondem ao ensino de arte.

Veremos que existem, com efeito, três atividades distintas que são amiúde confundidas: A. A atividade da auto-expressão - o inato no indivíduo precisa comunicar seus pensamentos, sentimentos e emoções a outras pessoas. B. A atividade da observação - o desejo do indivíduo de registrar suas impressões sensoriais, de esclarecer seu conhecimento conceitual, de construir sua memória, de construir coisas que auxiliem suas atividades práticas. C. A atividade da apreciação - a resposta do indivíduo aos modos de expressão que outras pessoas dirigem ou dirigiram a ele, e, geralmente, a resposta do indivíduo aos calores do mundo dos fatos - a reação qualitativa aos resultados quantitativos de A e B (Read, 2001:230-231).

Herbert Read afirma que essas atividades são assuntos diferentes, embora todas sejam categorias pedagógicas do ensino de arte. Pode-se entender a ênfase atribuída às atividades de auto-expressão em detrimento das atividades de apreciação quando Read (2001:231) expõe:

Quanto à apreciação, esta pode, sem dúvida, ser desenvolvida pelo ensino, mas a apreciação, como vimos, está tão relacionada com os tipos psicológicos quanto a expressão; na medida porém em que, com apreciação, referimo-nos à resposta aos modos de expressão de outras pessoas, a faculdade pode se desenvolver como um dos aspectos da adaptação social, não podendo esperar que ela se manifeste muito antes da adolescência. Até então, o problema real é preservar a intensidade original das reações da criança às qualidades sensoriais da experiência - às cores, superfícies, formas e ritmos.

A arte-educação entendida como auto-expressão criativa "não crê que a função principal da educação artística consista na transmissão de normas e conhecimentos, subordinando a aquisição de saberes e habilidades à experiência individual do sujeito criador" (Agirre, 2005:219). Este aspecto alimentou nosso ideário educativo porque "buscava transcender o conhecimento da arte em benefício do crescimento pessoal, moral ou social" (Idem:232). 
Um modelo de educação artística baseada na auto-expressão precisa, pelo menos, duas condições que o façam viável: uma concepção da condição humana baseada na autonomia do sujeito e uma perspectiva epistemológica suficientemente flexível para aceitar as diferentes práxis artísticas e educativas que se originam da ação de tal sujeito. Isto é, uma perspectiva que oponha à crença de uma verdade objetiva, a possibilidade de múltiplas opções subjetivas derivadas das ações dos seres humanos livres ( Agirre: 2005:232).

\section{Continua o autor:}

Porém o pensamento estético que dá razão a esta concepção de arte e educação artística atenderia, além do mais, aos seguintes princípios filosóficos:

. A natureza é superior à arte.

. O sentimento é mais importante para o indivíduo que a razão e se encontra na base de toda experiência estética.

. A liberdade é um valor inquestionável do ser humano que deve manifestar-se também em suas relações com a arte.

- A atração humana frente à arte obedece ao impulso vital (Bérgson) mais que a razão.

. O objeto da arte é a expressão não a contemplação (Croce).

- A cultura é algo dinâmico em constante evolução, porque o homem evolui e progride.

- O característico do estético é o desinteresse, frente à utilidade (Kant).

- Os problemas mais acuciantes do ser humano não são os da história, senão os da identidade dos indivíduos. Identidade individual (eu) frente ideal coletivo (a história).

. A arte é jogo (Schiller), um simulacro de vida (Agirre: 2005:232).

Entre os princípios anteriormente citados o autor assevera que a liberdade se manifesta em dois aspectos que caracterizam dois eixos fundamentais da arteeducação correspondentes a estes princípios filosóficos: desinteresse e espontaneidade.

Foi Kant quem formulou a idéia de que o característico na experiência estética é o desinteresse. Isto vem significar que não é possível uma experiência estética - seja produzindo arte ou contemplando-a - se existe mediação interessada, (...) a verdade essencial da arte não pode ser apreendida, senão desinteressadamente vivenciada.

A segunda conseqüência do livre fazer da arte, gêmea em alguns aspectos ao do desinteresse, é a consideração da espontaneidade como paradigma do livre exercício do artista. Dizemos que quase são gêmeas porque a espontaneidade é a exemplificação perfeita do atuar desinteressadamente, isto é, de atuar seguindo só os ditados do 'impulso vital' (Agirre,2005:233). 
Em seu texto sobre a arte como expressão, a arte-educação como autoexpressão criativa, Agirre contribui para o entendimento de que abordar o ensino modernista em arte somente através das idéias e ações que se apresentaram como auto-expressão, disseminadas como espontaneísmo e nonsense, poderá ser uma adulteração do modernismo, como foi pensado inicialmente em arteeducação.

Em 1984 a Revista Ar'te, publicação de estudos de arte e arte-educação, em seu décimo número, apresentou ensaios que foram determinantes no curso da arte-educação. A Ar'te 10, como ficou conhecida, entre os textos que a compõe, fez conhecer aos educadores brasileiros o pensamento de Vicent Lanier. Seu artigo, Devolvendo arte à arte-educação, entre os primeiros a levantar esta problemática, já inicia contundente: "O que a arte-educação precisa é de um forte conceito central" (Lanier, 1984:4).

O autor, naquela ocasião, apontava para a importância da arte na educação porque a arte é importante por si mesma. Todos os aspectos do desenvolvimento pessoal ou crescimento individual que justificavam a arte na educação escolar não atribuíam diretamente à arte a aprendizagem da arte. Vicent Lanier desenvolveu quatro hipóteses para alcançar a proposição de "um forte conceito central". A primeira delas mostra que um indivíduo antes de entrar para a escola já vive uma experiência visual; isto faz com que nós, professores, apenas ampliemos o conhecimento ao qual o aluno já foi introduzido; a segunda aponta a diversidade das artes plásticas, que são mais do que algumas modalidades artísticas com categorias delimitadas, incluindo desde a produção artesanal até todas as mídias eletrônicas; como terceira hipótese, levanta-se a questão de que não é só a produção em ateliê que provoca a experiência estética visual; a quarta hipótese é que só aquele que está consciente da experiência estética pode ampliar o âmbito dessa experiência. 
Outros artigos também foram fundamentais para a mudança da visão modernista em arte-educação para uma visão pós-moderna: Destacam-se os de Brent Wilson e Marjorie Wilson e de Arthur Efland. Em Uma visão iconoclasta das fontes de imagem nos desenhos de crianças, Brent e Marjorie Wilson relatam suas pesquisas sobre os desenhos de crianças e referem-se logo no início do artigo ao pensamento de Arthur Efland:

Como podemos deixar de ver a forte influência da ilustração e da fotografia no desenho de crianças? Talvez a crença, de quase um século, de que a arte das crianças desenvolve-se naturalmente, conduza a práticas que suprimam - pelo menos nas aulas de arte - as influências adultas mais óbvias, ao mesmo tempo em que sutilmente "motivam" as crianças a produzir as concepções adultas de como a arte infantil deveria ser. Precisamente devido à crença no florescer natural da arte nas crianças, ela tornou-se aquilo que nós adultos, e especialmente os professores, fizemos (Efland, 1976:37-44). Nós encorajamos as crianças a produzirem a nossa imagem de uma arte infantil "natural", "criativa" e "espontânea" ao mesmo tempo em que fechamos os olhos para os desenhos reais - os copiados - que poderiam revelar a verdadeira natureza do aprendizado artístico (Wilson, B. e Wilson, M. in: Barbosa, 1997:58).

As pesquisas de Brent e Marjorie Wilson criaram oportunidades para que a atividade expressiva infantil fosse orientada para além do "natural, criativo e espontâneo", comprovando em suas ações de pesquisa que a criança aprende a "formar seus próprios signos configuracionais principalmente por meio da observação do comportamento-de-fazer-signos-configuracionais de outras pessoas, por observar inicialmente que outras pessoas fazem desenhos", e terminam o parágrafo de maneira contundente: "Sim, estamos dizendo que, sem modelos para serem seguidos, haveria pequeno ou nenhum comportamento de realização de signos visuais nas crianças" (Idem:61).

Além deste aspecto específico - o desenho infantil nas aulas de arte - como vimos anteriormente, encontram-se na literatura produzida por Arthur Efland discussões sobre o contexto histórico do ensino de artes visuais que também contribuíram para uma reflexão e atualização sobre objetivos didáticos e conteúdos. Quando argumenta sobre pesquisas que apontaram a falta de qualidade na educação artística nos anos 80, ele afirma: "Os culpados de dita falta 
de estima intelectual são em certa medida os próprios educadores artísticos, por causa de sua omissão em ensinar apreciação artística por medo de impedir a expressão pessoal" (Efland, 2002:380). Arthur Efland, Brent e Marjorie Wilson contribuíram significativamente para uma revisão sobre as posturas de professores de arte frente ao uso de imagens nas aulas de arte. ${ }^{14}$

Assim, o objetivo modernista de desenvolver a criatividade foi sustentado pelos princípios da Escola Nova, a qual baseada filosoficamente em Dewey, psicologicamente em Claparède e metodologicamente em Decroly, buscou o desenvolvimento do conteúdo no interesse do aluno, dirigida pelo método de centro de interesse e pelas necessidades e capacidades características das crianças (Barbosa,1982:41-44). A base filosófica da Escola Nova entendia que 0 processo educativo formal precisava ter uma finalidade prática, preparando os indivíduos para agirem concretamente na sociedade. A dinâmica da Escola Nova estava em sintonia com os ideais sociais modernos - pretendia-se uma sociedade

constituída a partir dos preceitos do trabalho produtivo e eficiente, da velocidade das transformações, da interiorização de normas de comportamentos otimizados em termos de tempos e movimentos e da valorização da perspectiva da psicologia experimental na compreensão 'científica' do humano, tomado na dimensão individual.

O trabalho individual e eficiente tornava-se a base da construção do conhecimento infantil. Devia a escola, assim, oferecer situações em que o aluno, a partir da visão (observação), mas também da ação (experimentação) pudesse elaborar seu próprio saber. Aprofundava-se aqui a viragem iniciada pelo ensino intuitivo no fim do século XIX, na organização das práticas escolares. Deslocado do 'ouvir' para o 'ver', agora o ensino associava 'ver' a 'fazer'.

Nesse sentido, uma nova dinâmica impulsionava as relações escolares. O aluno assumia soberanamente o centro dos processos de aquisição do conhecimento escolar: aprendizagem em lugar de ensino (Vidal in Lopes, 2000:498).

O objetivo modernista de desenvolver a criatividade que durante muito tempo foi norteador das atividades artísticas escolares passou a ser questionado. Os

\footnotetext{
${ }^{14}$ Há uma espécie de acordo internacional que diz que o pós-modernismo em arte-educação começa com a chegada da imagem na sala de aula, com a idéia de arte como cultura.
} 
anos 80 foram de politização dos arte-educadores, de revisão de práticas, de busca de abordagens pedagógicas adequadas e conteúdos. Negou-se o nonsense.

Entretanto, pode-se afirmar que nos últimos anos este sentido de nonsense vem sendo transformado. Analice Dutra Pillar (1999:11)esclarece:

A partir dos anos 80 , no Brasil, o ensino de arte começa a ser repensado em novas bases conceituais e revisado quanto a sua relação com as pesquisas contemporâneas em arte. Os professores passaram a trabalhar não só a produção da criança e do adolescente, mas também a leitura da imagem e a contextualização histórica. Surgiram, também, as releituras, enquanto produções realizadas com base em obras de arte.

A disseminação de novas propostas entre arte-educadores brasileiros, nutrida pela ânsia de aplicar fórmulas prontas e eficazes, contribuiu para a adoção de modelos em sala de aula. Em muitos casos, leitura e releitura renovaram o sentido de nonsense, foram adotadas sem reflexão sobre seus conceitos e suas possibilidades de adequação à realidade da comunidade escolar.

Na última década do século $X X$ e no início deste século surgiram propostas pré-formatadas que apresentam aos professores imagens selecionadas por curadores distantes da realidade escolar, distantes da "colcha de retalhos da vovó", da qual nos fala Lanier (1984:6).

É importante projetar o ensino de arte aprendendo com as questões já superadas. É fundamental que o foco do ensino de arte esteja na arte. Talvez esta questão não esteja realmente superada. Ações sociais ou fundadas na psicologia e outras áreas de conhecimento vêm afastando a arte do ensino da arte. Para que o foco esteja na arte, é necessário pensar: que arte? $O$ que os professores consideram como arte? 
2.1.2. Leitura de imagens: a contemporaneidade no ensino

O entendimento do termo leitura em ensino de arte originou-se com a divulgação das ações desenvolvidas no Museu de Arte Contemporânea da Universidade de São Paulo. O trabalho de pesquisa e de atendimento dos arteeducadores do museu, na ocasião sob coordenação de Ana Mae Barbosa, estava fundamentado na apreciação da obra de arte, na história da arte e no fazer artístico.

Em 1987 comecei um programa de arte-educação no Museu de Arte Contemporânea, combinando trabalho prático com história e leitura de obras de arte. A metodologia utilizada para a leitura de uma obra de arte varia de acordo com o conhecimento anterior do professor, podendo ser estética, semiológica, iconológica, princípios da gestalt, etc. (Barbosa,1991:19).

A atenção para articular os conhecimentos dos professores à proposta de leitura da obra já eram evidentes. Continua a autora:

Temos sido muito cuidadosos para não transformar a leitura de uma obra de arte num simples questionário. Esta simplificação está acontecendo com a metodologia da Getty Foudation nos Estados Unidos apesar da estrutura teórica e complexa construída por Harry Broudy, porque os professores de arte estão reduzindo a análise ou apreciação artística a um jogo de questões e respostas - um mero exercício escolar que leva a leitura a um nível mediocrizante e simplifica a condensação de significados de uma obra de arte, limitando a imaginação do apreciador (Idem).

E completa:

Nossa idéia de leitura da imagem é construir uma metalinguagem da imagem. Não é falar sobre uma pintura mas falar a pintura num outro discurso, às vezes silencioso, algumas vezes gráfico, e verbal somente na sua visibilidade primária (Ibidem).

No mesmo livro, $A$ imagem no ensino da arte, e mais uma vez a história do ensino de arte sendo escrita por Ana Mae, encontra-se a denominação leitura e sua significação, num capítulo com o subtítulo A Metodologia Triangular: história da arte, leitura da obra de arte e fazer artístico. 
A metodologia de ensino da arte usada no Museu de Arte Contemporânea da Universidade de São Paulo integra a história da arte, o fazer artístico, e a leitura da obra de arte. Esta leitura envolve análise crítica da materialidade da obra e princípios estéticos ou semiológicos, ou gestálticos ou iconográficos. A metodologia de análise é de escolha do professor, o importante é que as obras de arte sejam analisadas para que se aprenda a ler a imagem e avalia-la; esta leitura é enriquecida pela informação histórica e ambas partem ou desembocam no fazer artístico (Idem:37).

Posteriormente, Ana Mae Barbosa em novo livro, Tópicos Utópicos, ao escrever o subtítulo Correções à Proposta Triangular, orienta professores de arte, seus leitores, a compreender em profundidade as conceituações em uso. Registra que "Sistematizada no Museu de Arte Contemporânea da USP (87/93), a Triangulação Pós-Colonialista do Ensino da Arte no Brasil foi apelidada de 'metodologia' pelos professores (...) gostaria de ver a expressão Proposta Triangular substituir a prepotente designação Metodologia Triangular" (Barbosa, 1998:33). Para a compreensão do termo leitura a autora apresenta detalhadamente a origem da Proposta Triangular:

A Proposta Triangular deriva de uma dupla triangulação. A primeira é de natureza epistemológica, ao designar os componentes do ensino/aprendizagem por três ações mentalmente e sensorialmente básicas, quais sejam: criação (fazer artístico), leitura da obra de arte e contextualização. A segunda triangulação está na gênese da própria sistematização, originada em uma tríplice influência, na deglutição de três outras abordagens epistemológicas: as Escuelas al Aire Libre mexicanas, o Critical Studies inglês e o Movimento de Apreciação Estética aliado ao DBAE (Discipline Bases Art Education) americano. (...) Foi, entretanto, o movimento de crítica literária e ensino da literatura americana Reader Response ${ }^{15}$ que, em diálogo com nossa especificidade terceiro-mundista, inspirou a designação de 'leitura de obra de Arte' para um dos componentes da triangulação ensino-aprendizagem (Barbosa, 1998:33-34).

Assim, a área de conhecimento ensino de arte introduziu o termo leitura nas suas atividades e estudos. Anteriormente, professores de arte não ousavam fazer

\footnotetext{
${ }^{15}$ Cfme Barbosa,1998:35: "O movimento Reader Response não despreza os elementos formais, mas não os prioriza como os estruturalistas o fizeram; valoriza o objeto, mas não o cultua, como os deconstrutivistas; exalta a cognição, mas na mesma medida considera a importância emocional na compreensão da obra de arte. O leitor e o objeto constroem a resposta a obra numa piagetiana interpretação do ato cognitivo e, mais ainda, vigotsquiana interpretação de compreensão do mundo. Assimilação e acomodação na relação leitor-objeto (reader-response) são os processos fundamentais que se impõem."
} 
leituras, tratava-se de apreciação da obra ou apreciação artística, mas como conhecimento ligado à história da arte e sob responsabilidade de historiadores e críticos. A ênfase na leitura ampliou-se para

leitura de palavras, gestos, ações, imagens, necessidades, desejos, expectativas, enfim, leitura de nós mesmos e do mundo em que vivemos. Num país onde os políticos ganham eleições através da televisão, a alfabetização para a leitura é fundamental, e a leitura da imagem artística, humanizadora. (...) Este princípio de leitura como interpretação cultural, com muita influência de Paulo Freire, foi inicialmente experimentado na organização, cursos e oficinas do festival de Inverno de Campos de Jordão em 1983, que podemos considerar a primeira experiência pós-moderna de ensino da arte no Brasil (Idem:35).

Entretanto, o significado de leitura, repetindo a experiência americana, foi absorvido de maneira reduzida e superficialmente tratado pela maioria dos professores. A leitura passou a ser entendida como descrição e o fazer artístico como releitura. Ler um quadro, na prática dos professores, traduziu-se em perceber e interpretar linhas, cores, formas, texturas que constituem a imagem. Reler traduziu-se em copiar ou rearranjar em outros suportes a obra "lida". Foi uma forma de apropriação, foi a maneira como professores, ávidos por qualificação das suas práticas, deram sentido e adaptaram aos seus contextos a proposta metodológica.

Além da preocupação com a redução conferida aos termos leitura e releitura, questiono se, na busca de qualificação e ressignificação de conteúdos para as aulas de arte, não se limitou a uma transmissão de conteúdos necessários para uma adaptação cultural, afastando nosso aluno de uma experiência mais consciente, mais concreta e direta. Esta redução e possíveis limitações na prática cotidiana do ensino de arte estão sendo gradativamente suplantadas como conseqüência da publicação de pesquisas e artigos, com o sério empenho de professores em refletir sobre suas ações.

Encontro aspectos comuns, que necessariamente devem ser valorizados nas aulas de arte na educação escolar, quando considero as implicações do ato 
de ler e de viver experiências. Maria Helena Martins em sua obra $O$ que é leitura, assinala:

Quando começamos a organizar os conhecimentos adquiridos, a partir das situações que a realidade impõe e da nossa atuação nela; quando começamos a estabelecer relações entre as experiências e a tentar resolver problemas que se nos apresentam - aí então estamos procedendo leituras (Martins, 1994:17).

A leitura implica uma interpretação, uma leitura subjetiva do objeto lido, das cores e formas apresentadas, das entrelinhas, dos silêncios e intervalos, das relações dinâmicas entre o objeto de leitura e nossas experiências de leitor. Não podemos esquecer que a leitura sempre será produção de significados, "não é encontrar o sentido desejado pelo autor (...) ler é, portanto, constituir e não reconstruir um sentido.(...) ler será, portanto, fazer emergir a biblioteca vivida, quer dizer, a memória de leituras anteriores e de dados culturais" (Goulemot in Chartier, 1996:108).

Na conferência de abertura do I Congresso sobre o Ensino das Artes nas Universidades, em 1992, na Universidade de São Paulo, João Alexandre Barbosa, não negando a importância dos conteúdos da arte, mas questionando que estes conteúdos possam "resumir" a obra de arte a modelos de apreensão e reduzindo a arte à condição de objeto de conhecimento, enfaticamente afirmava: "A relação entre ensino e arte deixa, quase sempre, à margem, e por conta da intuição, aquilo que, creio, parece ser o fundamental: a capacidade da arte em transcender modelos de apreensão" (Barbosa, 1993:19). E completa,

Há leituras e leituras: aquela que imagino para estabelecer vínculos enriquecedores entre as artes e o ensino das artes não se deve limitar às decifrações de conteúdos ou, o que vem a dar na mesma coisa, às reduções, nas obras, dos objetos de representação. Penso, sobretudo, naquela leitura tal qual está, rutilante, numa certa definição de Paul Valéry para o poema 'hesitation entre le son et le sens'. Quer dizer, o poema não como resolução, mas como hesitação no trabalho primordial do poeta: a articulação entre o som e o sentido de onde é possível obter uma significação. Uma e não a: o trabalho de recuperação da significação da obra, que cabe ao leitor ou ao espectador, uma vez liberto de uma possível tarefa pacificadora, mas antes 
hesitante, é tão proliferador de significação quanto a 'hesitação' original do artista (Barbosa,1993:20-21).

Ao encerrar aquela conferência, João Alexandre Barbosa perguntava: "Será que a reflexão sobre o ensino das artes é capaz de incluir essa tensa 'hesitação' teórica (para emprestar o termo de Valéry) com a conseqüente recusa dos modelos de compreensão pacificadores, mas redutores?" (Idem, p.23).

Ler é interpretar, com base em vivências, em conhecimentos adquiridos, conhecimentos que no caso das artes visuais não se restringem especificamente a conceitos e conteúdos do âmbito das artes. Mas os conhecimentos da linguagem visual não devem ser ignorados, eles são uma base para a atribuição de significados. Um leigo ou nosso aluno é capaz de ler uma imagem num estágio inicialmente pessoal. Porém, precisa de um referencial mínimo para o acesso à arte; caso contrário, se nem a linguagem visual ele conhece, como vai atribuir "outros" significados? Não se pretende, com isso, contribuir para a elitização da arte, considerando que só é capaz de ler uma imagem aquele que domine os códigos de apreensão desta linguagem. E sobre apreensão, relembro João Alexandre Barbosa sobre o quanto o ensino de arte na educação escolar pode se fundamentar em modelos de compreensão redutores. Acredito que para os nãoiniciados na área de arte é possível que sejam capazes de esboçar sentido, alguma interpretação para a imagem com que estão em relação, é certo que tenham uma experiência.

A leitura de imagem se dá desde os primeiros momentos de vida do ser humano. Sabemos que o recém-nascido inicialmente enxerga vultos, que no desenvolver do primeiro mês já poderá enxergar com total nitidez. Este, aliado aos outros sentidos, vai se tornar um modo de contato com o mundo e com o outro. A imagem é uma das formas concretas com que nos sentimos inseridos no mundo. Segundo Maffesoli, a imagem "permite, além ou aquém das mediações, aceder a uma espécie de conhecimento direto, conhecimento vindo da partilha, da colocação em comum das idéias, evidentemente, mas também das experiências, 
dos modos de vida e das maneiras de ser" (1995:102). Maffesoli, em sua sociologia contemporânea, confirma a imagem como

o que permite o estar-no-mundo de cada indivíduo, ou de todo o conjunto social, o que funda o estar-junto de toda organização política ou social é, em suma, a imagem, o ver, o ser visto (...) não há nenhum aspecto da vida social que não esteja contaminado pela imagem (Maffesoli, 1995:97,137).

Enxergamos através dos nossos olhos; através das imagens percebidas 0 mundo exterior invade o ser interior. "Lembrem-se da bela observação de Novalis: 'o exterior é um interior elevado ao estado de mistério"' (Maffesoli,1995:139). Percebemos o mundo fora, mas esta imagem se forma dentro de nós, permitindo ao ser humano constituir-se e ser constituído pela expressão de uma época. Assim como há diferenciações básicas na forma pela qual respondemos a um estímulo, a imagem também é construída e percebida segundo a individualidade de cada ser.

Se dizemos que dois artistas pintam "a mesma" paisagem, descrevemos a nossa experiência estética muito inadequadamente. Do ponto de vista da arte tal pretenso 'mesmo' é completamente ilusório. Não podemos falar de uma e mesma coisa como matéria de ambos os pintores. Pois o artista não retrata ou copia um certo objeto empírico (...) O que ele nos dá é a fisionomia individual e momentânea da paisagem (Cassirer apud Pillar,1999:13).

Ou ainda, continuando com o pensamento do autor:

O olho seleciona, organiza, discrimina, associa, classifica, analisa, constrói. Não atua como um espelho que, tal como capta, reflete; o que capta já não o vê como tal e qual, como dados sem atributo algum, senão como coisas, alimentos, gentes, inimigos, estrelas, armas. Nada se vê despido ou despidamente. Os mitos do olho inocente e do dado absoluto são cúmplices terríveis (Idem).

Desta forma, estamos fazendo leituras das imagens e do cotidiano com um olhar impregnado de experiências anteriores. $O$ ensino de arte, pois, alcança a contemporaneidade da arte, compreendendo que o "conceito forte central" que Lanier (1984) propôs para mudanças é centrar o ensino nas imagens e na própria arte. 
Para tanto, a leitura de imagens, de todo tipo de imagens, a leitura da diversidade de experiência visual, do meio ambiente, do contexto urbano, dos objetos do cotidiano, é fundamental. A leitura é imprescindível para que o sujeito possa se situar no mundo. É imprescindível para o professor, pois antes de abordar as diferentes possibilidades de leitura com seus alunos, é necessário que ele mesmo saiba fazer e faça leituras.

Assim como o aluno já traz consigo experiências visuais (as quais nos processos de ensino o professor vai criar procurar ampliar), segundo Lanier, o professor também traz as suas. E são as experiências visuais anteriores do professor que vão determinar as suas escolhas. Todo professor traz em si sua herança cultural, que usa para interpretar e agir no mundo. Idéias, músicas, objetos, imagens, roupas,

a tradição de artesanato popular: aquelas colchas feitas pela vovó, a velha mobília que herdamos de nossas famílias, o porta-guardanapos esculpido de barbatanas de baleia. Esses não são propriamente a arte nobre dos museus mas freqüentemente, nos proporcionam pelo menos o mesmo tipo de prazer de visão que associamos às mais honoríficas artes (Lanier, 1997:48).

Lanier refere-se à experiência estética visual que qualquer pessoa pode vivenciar antes de entrar para a escola ou fora dela. O que enfatizo é a diversidade de estímulos que provocam experiências visuais. Destaco novamente o que Lanier continua afirmando:

Outra, e talvez mais ampla, categoria desses estímulos que provocam respostas estéticas sem o benefício da educação formal são as artes de massa. Já se escreveu tanto sobre isso que talvez seja desnecessário discorrer sobre elas. De qualquer maneira pode-se dizer que as histórias em quadrinhos, roupas, cartazes, pôsteres, televisão, filmes e todas as outras parecem gerar respostas em todos nós, mesmo aqueles sem treinamento em arte, de uma maneira pelo menos similar à que experimentamos com relação às Belas Artes (Idem). 
$\mathrm{Na}$ introdução deste trabalho, apresentei algumas perguntas norteadoras. Entre elas: Quais imagens professores de arte selecionam para apresentar aos seus alunos? Serão imagens de obras clássicas? Modernistas? Contemporâneas? Serão reproduções da arte européia? Serão reproduções da arte de distintos grupos étnicos? Serão reproduções de obras de artistas locais? Serão imagens produzidas pela cultura visual? Relembrar estas questões torna-se importante para compreender o encadeamento dos temas que vão sendo abordados.

Neste capítulo, no item 2.1., Tempos da imagem no ensino de arte, venho tratando dos antecedentes e da introdução dos conceitos de leitura na aula de arte. Esta discussão leva a abordar aspectos do modernismo e pós-modernismo na arte e no seu ensino, o que será tratado no item 2.2., Tempos da arte. Entretanto, se discorro sobre as experiências visuais que qualquer pessoa pode vivenciar antes de entrar para a escola ou fora dela, ressalto que este é um caráter do pluralismo pós-moderno. Nessa direção, Ivone Richter (2003:50) observa:

O modernismo e o pós-modernismo apresentam visões contrastantes sobre a natureza da arte: enquanto o modernismo considera a arte como um fenômeno único, envolvendo objetos distintos com a finalidade de prover uma desinteressada experiência estética, o pós-modernismo vê a arte como uma forma de produção e reprodução cultural, que pode somente ser compreendida dentro do contexto e dos interesses das suas culturas de origem e apreciação. Os (as) esteticistas modernistas condenam as preferências artísticas do público leigo em arte e promovem uma posição de exaltação para as artes visuais, enquanto no pós-modernismo busca-se dissolver as fronteiras entre a arte dita erudita e a popular, condenando-se o elitismo.

A leitura de imagens está diretamente relacionada à leitura do mundo local ${ }^{16} \mathrm{e}$ cotidiano, às preferências, às experiências perceptivas anteriores do professor e dos alunos.

\footnotetext{
16 "Ana Mae Barbosa salienta 'a idéia de reforçar a herança artística e estética dos alunos com base em seu meio ambiente'. No entanto, ela imediatamente adverte que 'se não for bem conduzida, pode criar guetos culturais e manter grupos amarrados aos códigos de sua própria cultura sem possibilitar a decodificação de outras culturas' "(Richter, 2003:47).
} 
O ensino das artes sofre, a partir daí, uma mudança paradigmática: no modernismo, tende a aplicar critérios da gramática visual e da excelência artística, mas esse tipo de visão artística isola a arte do restante das experiências; já no pós-modernismo, o ensino da arte está potencialmente conectado com a vida, desmanchando-se as fronteiras entre a arte e 0 contexto cultural mais amplo ao qual ela pertence (Richter,2003:50).

Os tempos da imagem no ensino da arte sofrem mudanças com a aproximação ao cotidiano e dissolução de fronteiras entre popular e erudito, marginalizado e institucionalizado, rico e pobre, sucata e materiais artísticos. $\mathrm{O}$ mundo local volta a receber um olhar diferenciado nas aulas de arte. Já não se aborda somente a arte européia, os artistas modernistas, as reproduções de obras que estão nos museus. O ensino de arte estando "potencialmente conectado com a vida" ressalta a importância dos princípios educacionais que serão apresentados no capítulo que segue, orientados pela pedagogia, ética e estética de Paulo Freire. 


\subsubsection{Leituras de mundo: a estética em Paulo Freire}

Ao tratar o tema leitura de imagens e da arte no campo do ensino, retorno à obra de Paulo Freire com vistas a melhor apresentar a questão da leitura de imagens. Isto porque se a alfabetização, ou a apropriação da linguagem verbal, é imprescindível para o acesso à cidadania, num tempo em que as imagens e os modos de produção de imagens se multiplicam e diversificam, penso que o acesso à compreensão das imagens é também imprescindível à cidadania.

Do método Paulo Freire de alfabetização tomo o sentido de leitura de mundo para associá-lo ao ensino de arte e leitura de imagens. Quando professoras de arte oferecem aos seus alunos imagens para ler, estariam desenvolvendo um pensamento crítico, para fazer frente à avalanche ideológica das imagens e mídias? Estariam reforçando, como muitas vezes se faz, uma ligação dos alunos com o mundo do consumo?

A importância da pedagogia de Paulo Freire, no Brasil e no mundo, vem de sua prática que propicia aos estudantes o crescimento em consciência social enquanto se alfabetizam. Estes tomam a realidade em suas mãos enquanto a escrevem no papel. Freire ressalta o compromisso de transformar a educação que gera estudantes silenciosos e calados, que por não refletirem, não falarem, não escreverem, permanecem marginais à história e à construção da vida humana. Sua proposição e realização são de

uma educação que possibilitasse ao homem a discussão corajosa de sua problemática. De sua inserção nesta problemática. Que o advertisse dos perigos de seu tempo, para que consciente deles, ganhasse a força e a coragem de lutar, ao invés de ser levado e arrastado à perdição de seu próprio 'eu', submetido às prescrições alheias. Educação que o colocasse em diálogo constante com o outro. Que o predispusesse a constantes revisões. A análise crítica de seus 'achados'. A uma certa rebeldia, no sentido mais humano da expressão (Freire,1983:90). 
Acredito realmente que, na contemporaneidade, e sempre, com todo seu dinamismo, a educação seja compreendida como "uma educação que fizesse do homem um ser cada vez mais consciente de sua transitividade ${ }^{17}$, que deve ser usada tanto quanto possível criticamente, ou com acento cada vez maior de racionalidade" (Freire, 1983:90).

Percorrendo os caminhos da fenomenologia, do existencialismo e concepções dialéticas, Paulo Freire constrói uma pedagogia preocupada com a libertação do homem submetido aos contrastes da hegemonia e inferioridade, da riqueza e pobreza, e às armadilhas dos privilégios sociais. Acredita que a vocação do ser humano é ser mais (1987:81), o que se realiza, segundo o autor, pelo acesso aos bens culturais.

É certo que existem diferenças entre a linguagem verbal e a linguagem visual. Como exemplo, quem não é alfabetizado, mesmo que consiga ler uma ou outra palavra de um texto, não consegue estabelecer os nexos para chegar á sua significação. Isto porque não existem analogias diretas da linguagem verbal com o que ela significa. Diferentemente, segundo Ramalho e Oliveira (1998), na linguagem visual, mesmo que se desconheça estilo, autor, origem ou outro aspecto sobre a imagem, qualquer leigo pode deduzir significações, ou por analogia com o mundo natural ou pelos efeitos de sentido que cor, forma e outros aspectos sugerem. O problema é que, ao conseguir deduzir significações as mais superficiais e óbvias, as pessoas - alunos e mesmo professores - dão-se por

\footnotetext{
${ }^{17}$ Conforme se entende em Paulo Freire, 'transitividade' é qualidade de mudança. Continuando a citação, em Educação como prática da liberdade, 1983, p.90, lê-se: "A própria essência da democracia envolve uma nota fundamental, que lhe é intrínseca - a mudança. Os regimes democráticos se nutrem na verdade de termos em mudança constante. São flexíveis, inquietos, devido a isso mesmo, deve corresponder ao homem desses regimes, maior flexibilidade de consciência". Sobre o caráter de transitividade do homem, Paulo Freire faz seu depoimento em Pedagogia da autonomia, 1996, p.58: "Gosto de ser homem, de ser gente, porque não estou dado como certo, inequívoco, irrevogável que sou ou serei decente, que testemunharei sempre gestos puros, que sou e serei justo, que respeitarei os outros, que não mentirei escondendo seu valor porque a inveja de sua presença no mundo me incomoda e me enraivece. Gosto de ser homem, de ser gente, porque sei que minha passagem pelo mundo não é predeterminada, preestabelecida. Que o meu 'destino' não é um dado, mas algo que precisa ser feito e de cuja responsabilidade não posso me eximir".
} 
satisfeitas e se equivocam pensando ter esgotado as possibilidades de significação.

O acesso a bens culturais tem sido uma das ações em educação, entretanto nem sempre políticas públicas e privadas contribuem para as relações do sujeito com a realidade. Pode-se até afirmar que bens culturais tornaram-se, em alguns casos, armadilhas de consumo. As imagens ou reproduções de obras nas aulas de arte estariam sendo deslocadas para uma ação de dominação em detrimento de uma situação de abertura para leituras de mundo?

Nos processos de alfabetização de adultos, mais do que ler palavras, Paulo Freire ensinou a ler o mundo, estar no mundo, ser sujeito no mundo. Este mesmo sentido procura-se para a leitura de imagens no ensino de arte. Lendo a imagem, também podemos ler o mundo, criando diálogos com a realidade.

A partir das relações do homem com a realidade, resultantes de estar com ela e estar nela, pelos atos de criação, recriação e decisão, vai ele dinamizando o seu mundo. Vai dominando a realidade. Vai humanizando-a. Vai acrescentando a ela algo que ele mesmo é fazedor. Vai temporalizando os espaços geográficos. Faz cultura (Freire,1984:43).

E ainda:

O jogo destas relações do homem com o mundo e do homem com os homens, desafiado e respondendo ao desafio, alterando e criando, que não permite a imobilidade, a não ser em termos de relativa preponderância, nem das sociedades, nem das culturas. E, na medida que cria, recria e decide, vão se conformando as épocas históricas. É também criando, recriando e decidindo que o homem deve participar destas épocas (Ibidem).

Conforme se fez referência no capítulo anterior, ler é atribuir, é criar significado em diálogo com o que se lê. Esta acepção se faz em encontro com as experiências de quem lê. $\mathrm{O}$ que se fundamenta com a palavra de Paulo Freire e se aplica ao ensino de arte é o ato dialógico. Sua teoria do conhecimento distingue que conhecer e pensar estão conectados à relação com o outro. 
O diálogo se impõe como caminho pelo qual os homens ganham significação enquanto homens. Por isto, o diálogo é uma exigência existencial. E, se ele é o encontro em que se solidarizam o refletir e o agir de seus sujeitos endereçados ao mundo a ser transformado e humanizado, não pode reduzir-se a um ato de depositar idéias de um sujeito no outro, nem tampouco tornar-se simples troca de idéias a serem consumidas pelos permutantes. (...) É um ato de criação (Freire, 1987:79).

Este ato de criação, não diferente do que se faz em arte, e em seu ensino, é um posicionamento pessoal de abertura ao diálogo com o mundo, com o outro, com a arte, com a imagem. O ensino, orientado por uma reflexão crítica sobre a prática, "não é transferir conhecimento, mas criar as possibilidades para a sua produção ou a sua construção" (Freire, 1996:25).

Assim, encontra-se em Paulo Freire que o processo de leitura é diferenciado de um ato de "domesticar-se ao texto", onde o leitor,

temeroso de arriscar-se, fala de suas leituras quase como se estivesse recitando-as de memória - não percebe, quando realmente existe, nenhuma relação entre o que leu e o que vem ocorrendo no seu país, na sua cidade, no seu bairro. Repete o lido com precisão mas raramente ensaia algo pessoal. Fala bonito de dialética mas pensa mecanicistamente. Pensa errado (Idem:30).

Comenta o mesmo autor, mais adiante:

A leitura verdadeira me compromete de imediato com o texto que em mim se dá e a que me dou e de cuja compreensão fundamental me vou tornando também sujeito. Ao ler não me acho no puro encalço da inteligência do texto como se fosse ela produção apenas de seu autor ou de sua autora (Ibidem).

Retomando as palavras citadas de Paulo Freire, encontra-se para leitura o sentido de superação de um "ato de depositar idéias de um sujeito no outro", de "domesticar-se ao texto", de "repetir o lido com precisão". Relega-se um significado de leitura como algo exterior e de certa forma disciplinar, para compreendê-la é preciso superar caricaturas de leitura e incluir dinâmicas culturais diversificadas. Leitura verdadeira compromete e faz ensaiar algo pessoal; assim, penso que o sentido de leitura é fundamentado no princípio de conscientização. 
Neste aspecto, cito novamente Paulo Freire para evidenciar um entendimento de conscientização como desenvolvimento crítico, como relação consciência-mundo.

A conscientização implica que ultrapassemos a esfera espontânea de apreensão da realidade (...) A conscientização é, neste sentido, um teste de realidade. Quanto mais conscientização, mais se 'des-vela' a realidade, mais se penetra na essência fenomênica do objeto, frente ao qual nos encontramos para analisá-lo. Por essa mesma razão, a conscientização não consiste em 'estar frente a realidade' assumindo uma posição falsamente intelectual. A conscientização não pode existir fora da 'práxis', ou melhor, sem o ato açãoreflexão (1980:26).

A conscientização, o olhar mais crítico para a realidade, se apresenta como um processo contínuo, como uma atitude que não se esgota, pois a cada nova realidade, nova reflexão se faz. O ato ação-reflexão constitui a unidade dialética entre consciência e mundo, é o que faz as professoras escolherem imagens que possam ser discutidas conforme o contexto dos alunos e o contexto da produção artística, entre outros assuntos.

A leitura que faço da obra de Paulo Freire contribui para compreender as escolhas de imagens feitas pelas professoras de arte. Além do entendimento do termo leitura propriamente dita, Paulo Freire ajuda a abranger o reconhecimento de que algumas orientações educacionais, tais como conteúdos, recursos e procedimentos de ensino, ainda estão presas aos bens culturais de instituições hegemônicas.

Conforme evidenciarei na apresentação dos diálogos com as professoras e nas fotografias por mim produzidas na pesquisa, a reflexão crítica provocada por Freire ajuda a ver que as atividades criadoras das professoras poderiam ser motivadoras e eficientes em suas aulas de arte, repercutindo na transformação, autonomia, valorização das professoras. Estas atividades, geralmente como lazer ou complementação de renda salarial, são as produções particulares, subjetivas, expressivas que as professoras realizam em trabalhos como desenhos, colagens, pinturas em tela, tecido e madeira, confecção de caixinhas, adereços para a casa, 
para o corpo e para a escola, personalização de materiais didáticos, utensílios, vestiário e outras criações baseadas na vida cotidiana. Mais que algumas imagens escolhidas de livros, catálogos e reproduções de obras distantes do contexto cultural da comunidade, a interpretação da leitura de Paulo Freire é um incentivo para afirmar que a arte na educação escolar pode romper com os contrastes popular e erudito, marginalizado e institucionalizado, rico e pobre, sucata e materiais artísticos.

A estética que se apresenta na ética educacional de Paulo Freire está em consonância com os ideais da contemporaneidade, em consenso com a reflexão e a produção da arte reconhecida como pós-moderna. Para as professoras este pensamento provoca valorização da cultura local, e destaco, em diálogo com os saberes da arte necessários ao ensino, conhecendo arte e sua história através da apreciação e dos percursos de produção. A leitura de Paulo Freire ajuda a compreender que a escolha de imagens para serem apresentadas na aula de arte precisa provocar diálogo com o mundo atual, diálogo entre os professores e alunos sobre diferentes contextos de produção da arte. Paulo Freire me inspira a afirmar que escolher imagens para aprender sobre arte e vivenciar experiências artísticas exige abertura de pensamento e um complexo, diversificado e infinito repertório visual contextualizado, com significação. Nas imagens escolhidas pelas professoras percebo seu grau de conscientização, princípio educacional de Paulo Freire. 


\subsection{TEMPOS DA ARTE}

$\mathrm{Na}$ introdução deste trabalho relatei algumas das minhas memórias de imagens mais remotas. Neste capítulo volto as minhas memórias de imagens, porém desta vez algumas mais recentes. Imagines ilustrare, aqui, vem dar foco a uma imagem publicada em revista, imagem que provocou perturbamento e reflexões no campo do ensino de arte. Diariamente somos submetidos, sim, submetidos, porque nem tudo o que vemos é escolha pessoal, a diferentes mídias e suas imagens. Muitas são as imagens que nos causam diversos sentimentos: compaixão, revolta, alegria, culpa, otimismo. Contudo, esta a que faço referência foi apresentada como representação da arte em publicação de fácil acesso.

Entre as imagens buscadas pelos professores de artes visuais, além dos materiais distribuídos em exposições, estão algumas das revistas de circulação nacional. Em março de 2004, sob o título O corpo e a ética do escândalo, a revista Bravo publicava artigo de Gisele Kato sobre o trabalho - prefiro chamar assim, aceitando as indagações sobre o dilema: são ou não são obras de arte? - do médico plastinador Gunther von Hagens. Pode-se até sugerir que a atitude de von Hagens tem intenção ou referencial na arte, pois, ao dissecar um cadáver no palco de um auditório, refere-se, em performance, à cena criada por Rembrandt em $A$ lição de anatomia do Dr. Tulp, ou apresenta um corpo plastinado da mesma maneira como Salvador Dali representou $A$ Vênus de Gavetas.

Considero que supostamente muitos professores de arte leram o artigo, visualizaram as reproduções, viram as imagens da exposição Body Worlds em jornais, revistas, televisão ou internet. Não há como negar ou evitar, no ensino, obras que causam desconforto, até mesmo porque em arte já se está acostumado às bruxas de Goya, aos corpos de Francis Bacon, às cirurgias de Orlan. Entre outros artistas, ocorre mencionar Chris Burden quando em 1974 foi crucificado sobre a capota de um Volkswagen, ou sua mais divulgada performance Shoot : "'Às 19:45 um amigo me deu um tiro no braço esquerdo. Era uma bala de cobre de 
rifle longo, calibre 22. Ele estava a menos de cinco metros de distância'. A bala existe até hoje como relíquia "(Gardner, 1996:19).

Se na década de 70 as imagens não circulavam tão rapidamente como nos dias de hoje, o impacto da arte, para as aulas de arte, diluía-se nos registros, no tempo, na distância. Hoje, porém, o que se vê é que a arte não apenas representa, mas realiza, se apresenta em espetáculo diante do espectador. Ainda nos anos 70, Hermann Nitsch realizaou, em uma das suas performances com ovelhas, a crucificação do animal.

Qual a repercussão, numa aula de arte, de representações dessa natureza? Quais as possibilidades de ensino? Enquanto Nitsch, Burden ou Orlan criavam suas produções nas décadas de 70 e 80, nós, professores de arte, nos dedicávamos a processos de ensino que buscavam expandir a expressão criadora de nossas crianças. Chegamos à década de 90 propondo a leitura de imagens de obras pertencentes ao modernismo, entre outras. Obras amplamente difundidas em reproduções nos livros de arte, didáticos e outros suportes. Obras que sustentaram o discurso sobre a importância dos elementos básicos da linguagem plástica e que criaram a possibilidade de, nas aulas de arte, além dos fundamentos da expressividade humana, ensinar conteúdos com alguma segurança.

É importante esclarecer que as ações, performances e outras visualidades citadas no início deste capítulo são aqui tomadas não como exemplo e referência de arte contemporânea, mas como recurso para enfatizar uma problemática que se quer apresentar. Até porque temos outras infinitas expressões contemporâneas que, não sendo abjetas ou repulsivas, provocam prazer, reflexões e experiências estéticas. A dificuldade que se enfrenta diante de uma obra de arte contemporânea está no aparecimento de uma multiplicidade de códigos individualizados. É o fim das narrativas antes extraídas da vida, dos textos sagrados, da literatura, da ordem de composição com base nas regras de proporção, das harmonias musicais, da arquitetura, etc. A partir de então a arte 
apresenta a impossibilidade de ser expressão de um fundamento e passa a ser, como afirma Gerd Bornheim, "vontade de criação" (Martins, org. 2000:39).

A problemática que enfatizo nesta pesquisa se localiza nas características que são próprias do que chamamos pós-modernidade. Morreram as verdades absolutas, os fundamentos são vários. As respostas são muitas e não uma só. Há perturbação. Há conhecimentos diversos. Há imagens múltiplas. São múltiplos os sentidos. A questão é: como ensinar num contexto polissêmico? Como manter-se capaz de discriminação, análise, escolha, crítica, para assegurar uma interpretação?

Um professor de arte não fica numa situação diferenciada de qualquer espectador comum diante desta obra, pois a proposta inerente a ela é a de nos confrontar com a impossibilidade de dizê-la. Mas, se para ensinar precisamos dizer, ou se ensinar é uma atividade de perguntas, onde tudo é caminho, onde tudo se revira em pesquisa, onde tudo está sob o signo da crise da arte que se encontra dessacralizada, 0 ato do ensino estaria em inventar a si próprio pela presença da arte e do professor, num movimento que se integre à multiplicidade de leituras, sem excessiva preocupação com um tipo de mediação que denota um saber institucionalizado. Estaria ato do ensino em manter a confiança em suas escolhas advindas das informações e conhecimento que o professor possui e que vai organizando ele próprio como sujeito? 


\subsubsection{Cenário contemporâneo}

Em minhas memórias de imagens, mais uma foi lembrada. Desta vez uma imagem mental, produzida ao ler o conto $A$ terceira margem do rio. Do cenário imaginado fruto da vivência do conto de Guimarães Rosa, passo a discutir neste capítulo o cenário contemporâneo.

No "devagar depressa dos tempos" o cenário está mais instável do que em outros momentos vividos. "Os tempos mudavam, no devagar depressa dos tempos". É o que escreve Guimarães Rosa (2001:79-84):

Era a sério. Encomendou a canoa especial, de pau de vinhático, pequena, mal com a tabuinha da popa, como para caber justo o remador. Mas teve de ser toda fabricada, escolhida forte e arqueada em rijo, própria para dever durar na água por uns vinte ou trinta anos. Nossa mãe jurou muito contra a idéia.(...) Nossa casa, no tempo, ainda era mais próxima do rio, obra de nem quarto de légua: o rio por aí se estendendo grande, fundo, calado que sempre. Largo, de não se poder ver a forma da outra beira. $E$ esquecer não posso, do dia em que a canoa ficou pronta.(...)

Nosso pai não voltou. Ele não tinha ido a nenhuma parte. Só executava a invenção de se permanecer naqueles espaços do rio, de meio a meio, sempre dentro da canoa, para dela não saltar, nunca mais. A estranheza dessa verdade deu para estarrecer de todo a gente. Aquilo que não havia, acontecia. (...) não pojava em nenhuma das duas beiras, nem nas ilhas e croas do rio, não pisou mais em chão nem capim.(...)

(...) Se o meu pai, sempre fazendo ausência: e o rio-rio-rio, o rio - pondo perpétuo.

A construção foi especial, a canoa foi encomendada, fabricada em resistente material, firme, forte, segura. Quando pronta foi lançada ao rio, canoa e remador sem objetivo de chegar a lugar algum. Nem chão, nem beira. Navegar sobre o rio, este é o lugar. A projeção que se fez foi construir a canoa e estar no rio. A promessa da modernidade foi a construção da canoa? O cenário contemporâneo é estar no meio do rio? 
Nas interfaces de diversos campos dos saberes humano estão a complexidade e as incessantes transformações. Pensamento, arte, tecnologias geram a alteração das configurações das instituições. A estabilidade perene foi desautorizada.

Das promessas da modernidade do século $X X$, o novo milênio nos traz 0 saldo da inquietude e da incerteza. A globalização é a resposta, tão efêmera e flutuante como o próprio conceito que a agrega. Inovações tecnológicas e científicas revolucionam o viver e o pensar. Guerras e atentados terroristas põem em xeque nosso futuro enquanto espécie. Movimentos sociais e artísticos reestruturam os papéis sociais e mudam o foco do nosso olhar. O caos já não trabalha em função da ordem? Tornamo-nos passivamente mais humanos, diante de uma tecnologia que ameaça o próprio conceito de humanidade. Neste cenário a arte se encarrega de protagonizar o abismo que configura nossa existência. Moderno coexiste com não-moderno. Modernidade tardia. Tempos hipermodernos. Idade neobarroca. Pós-modernidade. Ou conforme lemos em Lyotard (1989:34):

O pós-moderno está já compreendido no moderno pelo facto de que a modernidade, a temporalidade moderna comporta em si o impulso para se exceder num estado que não é seu. (...) Devido à sua constituição, e sem descanso, a modernidade está grávida do seu pós-modernismo .

Em Lyotard, ao discutir o pós-moderno, encontramos o termo cenário, porém a opção desta nomeação para estes tempos deve-se também a uma interpretação de Calabrese (1987:13).

Será com um caráter, uma qualidade, um sinal geral, que poderemos procurar definir a nossa época? A resposta não é certamente fácil. Mas isto depende do facto de que a pergunta, por detrás da banalidade e simplicidade da sua formulação, esconde muitas armadilhas teóricas. Tentemos torná-la explícita.

Calabrese sustenta a dificuldade em dar nomes para apresentar e representar os tempos vividos. Indica possíveis maneiras de escapar de "armadilhas teóricas", 
apresentando as seguintes questões: "Primeira questão subterrânea: que significa 'época', e sobretudo, como é que é possível definir uma que seja 'nossa'?" (Idem).

Discute, em seguida, as classificações de "ordem geral", as separações por "blocos históricos", e pergunta onde se encontra o caráter para estas separações:

Segunda interrogação implícita: será lícito etiquetar períodos da história com motivos de ordem geral (ou pior, genérico)? Terceira pergunta pressuposta: porquê então procurar 'um' carácter para definir uma época? Será permitido separar tão nitidamente blocos históricos, diferenciando-os por homogeneidade com outros ou de outros? Quarto, último e mais grave problema: onde reside semelhante 'caráter'? Na psicologia das pessoas, nos comportamentos públicos ou privados, na história política ou econômica, na estrutura da sociedade, nas formas de pensamento, nas artes, nas ciências? (Ibidem).

O termo cenário, para não caracterizar época, além de sua habitual e conhecida utilização no campo das artes cênicas, vem sendo absorvido também pelo mundo das organizações empresariais para projetar futuros plausíveis e para desafiar os modelos mentais que limitam a imaginação e recursos. Cenário entendido como contexto, o contexto vivido num instante, instante fora do tempo cronológico, sem época definida. Cenário como lugar de imaginação e possibilidades. Cenários como lugares por onde passam histórias infinitamente variadas e infinitamente repetidas. Como definir estes tempos? É preciso definilos? Ou melhor, como referir-se a estes tempos? Antes da discussão sobre moderno, pós-moderno, contemporâneo, cabe esclarecer que ao tratar sobre o tempo que vivemos é importante reconhecer tempos múltiplos que se cruzam num só instante. $O$ entendimento que se faz aqui é o das possibilidades de interrelações de tempos distintos. O cenário já não será o primário e definido telão de fundo que alternadamente ao subir e descer de bambolinas mudará o contexto da história. O termo cenário também é apropriado para o nosso tempo por ser a configuração de uma atmosfera constituída por bastidores, gambiarras, móveis, utensílios, cores, luzes, sons, isto é, são muitos os elementos que contribuem para a criação de um tempo e espaço. 
Ao lermos o recorte do conto de Guimarães Rosa apresentado aqui, podemos vivenciar em pequena escala o que experimentamos ao ouvir, ler, contar histórias e outras narrativas. Há um princípio simbólico que nos faz romper com o pensamento linear e nos leva a vivenciar um pensamento analógico que abre o pensamento para outros planos da realidade. Transpomos o aspecto físico para pensarmos numa qualidade essencial expressiva do conto. Isto gera uma possibilidade de criar um cenário imaginário, cria-se o rio, as margens, a canoa, a vegetação, o pai, o filho, a ambiência com seus cheiros, movimentos, cores, e todo o mais que se apresente para a paisagem imaginada.

A combinação entre ciência e arte recomenda que se construam cenários para a concepção de uma idéia, mapas para as histórias ou contos; construir projeto no presente poderá ser conhecer o cenário que se apresenta e projetá-lo, gerando qualidades que apontem para a novidade, para a invenção, para o impacto. Entretanto, vale lembrar que projetar cenários, assim como a educação na contemporaneidade, é pensar numa sociedade mais diversa, distintamente dos tempos modernos quando projetar e educar significava preparar para o futuro e carregá-lo de expectativas.

A preocupação em promover uma ação educativa valorizando a arte como meio fundamental de desenvolvimento do conhecimento humano e o interesse na busca de qualificação e ressignificação de conteúdos voltados para a arte inserida num cenário contemporâneo propicia a procura de um equilíbrio entre a teoria e a prática educativa em arte.

Caracterizar o pensamento filosófico moderno e contemporâneo, diante de toda a produção existente, pode parecer dispensável, porém reconhecemos que a partir das guerras mundiais renunciou-se à construção de grandes sistemas fechados e, em transformação, optou-se por apresentar o que se pensa como precário, passageiro, provável. O período após a Segunda Guerra Mundial abrigou uma ruptura com o pensamento racional da modernidade e com todas as formas 
modernas de existir. Abriu-se mão, mesmo na ciência, do definitivo, único, verdadeiro, das doutrinas universais fechadas. Assim, obras abertas, textos fragmentários passam a ser freqüentes. Baudelaire já definia "a modernidade como o transitório, o fugidio, o contingente" (Foucault, 2000:342).

Os termos contemporâneo e pós-modernismo têm estado atrelados, e este último tem sido compreendido segundo a clássica delimitação de Eagleton (1998:7).

A palavra pós-modernismo refere-se em geral a uma forma de cultura contemporânea, enquanto o termo pós-modernidade alude a um período histórico específico. Pós-modernidade é uma linha de pensamento que questiona as noções clássicas de verdade, razão, identidade e objetividade, a idéia de progresso ou emancipação universal, os sistemas únicos, as grandes narrativas ou os fundamentos definitivos de explicação. Contrariando essas normas do iluminismo, vê o mundo como contingente, gratuito, diverso, instável.

Mais precisamente sobre pós-modernismo e arte:

Pós-modernismo é um estilo de cultura que reflete um pouco essa mudança memorável por meio de uma arte superficial, descentrada, infundada, autoreflexiva, divertida, caudatária, eclética e pluralista, que obscurece as fronteiras entre a cultura 'elitista 'e a cultura 'popular', bem como entre a arte e a experiência cotidiana (Idem, idem).

O debate recente sobre o tema moderno / pós-moderno tem como marca a heterogeneidade de posturas ${ }^{18}$. As várias posições indicam que há a procura de um perfil teórico que se molde às novas formas de conhecimento e de vida, dominantes nas últimas décadas do século XX e neste início de século XXI. Um ponto comum entre as várias posições é justamente o reconhecimento de que o projeto da modernidade tornou-se profundamente problemático e questionável. A palavra-chave é crise. Crise de paradigmas científicos, de política, de autoridade, de sujeito, crise da cultura.

\footnotetext{
${ }^{18}$ Alguns teóricos acreditam que os tempos atuais são de plena pós-modernidade. Entre estes figuram Lyotard, Baudrillard e Derrida, conforme salientado por Fridman (2000), assim como Vatimo (1996) e Jameson (1994). Durante os anos 80 muitos desses autores teriam rejeitado ou se distanciado do pós-moderno, porém seus nomes ficaram ligados a esses termos. Posturas como a de Habermas (1983) afirmam que a modernidade é ainda um projeto inconcluso.
} 
Nazario (2005), ao elaborar e descrever um quadro histórico do pósmodernismo, ao fim de sua análise, afirma:

Somos pós-modernos porque não podemos mais acreditar nas ideologias, já que todas traíram suas promessas: daí o desinteresse atual pelas idéias, pela política, pela coisa pública. Por outro lado, o ceticismo que define essa atitude pós-moderna é incapaz de enfrentar as ideologias que, apesar de já terem sobejamente realizado seu potencial de catástrofe, encontram ainda um grande público devoto nas massas modernas que sobrevivem na modernidade, recusando-se a tomar consciência da agonia de seu mundo (Nazario in Grinsburg e Barbosa, 2005:70).

\section{E conclui dizendo que}

para superar o impasse, será talvez necessário reexaminar as premissas da pós-modernidade, nelas descobrindo o cerne de sua irracionalidade que permanece encravado em sua racionalidade; aqui, também, a última palavra não deve ser deixada ao ceticismo, que tudo relativiza, nem ao positivismo, que tudo justifica; a última palavra será pelo criticismo, que tudo coloca em crise (Idem, idem).

A arte, nos modelos que a mantinham como simulacro, deixa de existir com critérios formais ou materiais determinados. Tudo o que era ordenado e estável se volatiliza, tudo o que era sagrado é dessacralizado. Se antes a obra nos acolhia e nos abria possibilidade de encontros com o ser da obra ou com o ser em si da condição humana manifesto na arte, o que passa a se manifestar é perplexidade, confusão, dúvida (Koneski, 2007). O descolamento da arte daquelas grandes questões nos aproxima e leva a olhar o cotidiano.

O paradoxo que começa a surgir para os professores de arte é que, inseridos na área de Educação - ainda norteada, mesmo que subliminarmente, por um ideal moderno de projeto, progresso e formação ${ }^{19}$-, deparam, não só em arte, com o

\footnotetext{
${ }^{19}$ Ao referir-me aos termos formação humana e formação de professores, faço a seguinte ressalva citando Collares, Cecília; Moyses, Maria; Geraldi, João. Educação Continuada: a política da descontinuidade. in: Educação e sociedade. no. 68/9. Campinas: CEDES, 1999. p.202-219: "De modo geral, sempre que nos interrogamos sobre 'formação', imediatamente outras expressões cognatas aparecem em nossa mente: informar, forma, fôrma. Essas relações paradigmáticas remetem, semanticamente, a uma noção absolutamente depreciativa: formar remete a enformar, pôr em forma - em suas duas leituras de f(o)(ô)rma.
} 
cenário que manifesta o fragmentário, o efêmero, o acidental e o descentrado. A educação, sendo ainda designada como o mundo moderno, chega à arte, em alguns procedimentos, com um sistema redutor já preparado, negando complexidades. O compromisso do professor de arte passa a ser não mais aquela remanescente responsabilidade da educação tradicional na continuidade das culturas e grandes representações ou narrativas, mas sim abrir-se ao outro novo compromisso de entrada num pensamento contemporâneo, numa atitude reflexiva sobre o devir da arte. Considero importante lembrar David Thistlewood: "Sejam quais forem as reações que as últimas manifestações da arte nos provoquem choque, prazer, repulsão, afeição, indiferença - parto da consideração de que nós temos a responsabilidade de ensiná-las, para que nossos estudantes possam absorvê-las criticamente" (Thistlewood in Barbosa, 2005:114).

Diante das muitas características do cenário, sistema cultural do qual fazemos parte, como o professor se configura neste contexto? Se o sujeito é um ser em construção, fragmentado, descentrado, sua identidade vive, nos termos de Lipovetsky, a condenação do presente? Mas o presente nos solicita a prospecção de cenários. Ou ainda, se o presente é condenação, vivenciar conscientes instantes de presença contribuirá para confirmar um paradoxo sem saída.

O sujeito pós-moderno não pode ser conceituado como tendo uma identidade fixa, essencial ou permanente. Para Stuart Hall ${ }^{20}$ a identidade torna-se uma

\footnotetext{
${ }^{20}$ Stuart Hall distingue três concepções de identidade. A primeira refere-se ao sujeito do lluminismo e é baseada num entendimento de pessoa que a vê como indivíduo totalmente centrado e unificado, dotado de razão, consciência e ação; o centro primordial do 'eu' é a identidade de uma pessoa. A segunda noção é a de sujeito sociológico, o qual reflete a crescente complexidade do mundo moderno, cuja consciência interior não é autônoma e auto-suficiente, mas sim formada na relação com os outros, que mediam os valores, os sentidos e os símbolos; nesta visão, o sujeito ainda tem um núcleo ou essência interior que representa o 'eu real', mas que é formada e modificada com os mundos culturais exteriores. A terceira concepção seria a do sujeito pósmoderno, onde há relação direta com o descentramento do sujeito cartesiano e sociológico, descentramento no qual se encontra, entre outros, o sujeito de que fala Foucault. Este autor realizou, numa série de estudos, uma espécie de 'genealogia do sujeito moderno', destacando um novo tipo de poder, o poder disciplinar. O poder disciplinar estaria preocupado em primeiro lugar com a regulação, onde vigilância seria o governo da espécie humana ou de populações inteiras, e, em segundo lugar, com o indivíduo e com o corpo. O objetivo deste poder regulador seria o de
} 
celebração móvel: formada e transformada continuamente em relação às formas pelas quais somos representados ou interpelados nos sistemas culturais que nos rodeiam. Não somente a biologia, mas também a história é quem define o sujeito que assume identidades diferentes em diferentes momentos e cenários. Identidades que não são unificadas ao redor de um 'eu' coerente: "Á medida que os sistemas de significação e representação cultural se multiplicam, somos confrontados por uma multiplicidade desconcertante e cambiante de identidades possíveis, com cada uma das quais poderíamos nos identificar - ao menos temporariamente" (Hall,2000:13). Esta idéia de sujeito perturbado e perturbador, e sua identidade, é associada ao surgimento do Modernismo, por meio dos movimentos estéticos e intelectuais produzidos naquele contexto. A multidão e a metrópole anônima servem de pano de fundo ao indivíduo isolado, exilado ou alienado. A literatura e as artes visuais testemunham este cenário através de sua leitura de mundo.

Embora a globalização seja um tema relativamente recente em nosso cotidiano, associado mais à questão econômica, seu gérmen foi lançado antes mesmo do século XX. A tendência à globalização já se encontrava enraizada na modernidade. O impacto mais profundo que a globalização causa sobre a identidade é apontado por Stuart Hall (2000:71):

\begin{abstract}
O tempo e o espaço são também as coordenadas básicas de todo o sistema de representação. Todo meio de representação - escrita, pintura, desenho, fotografia, simbolização através da arte ou dos sistemas de telecomunicação traduz os eventos numa seqüência temporal 'começo-meio-fim'; os sistemas visuais de representação traduzem objetos tridimensionais em duas dimensões. Diferentes épocas culturais têm diferentes formas de combinar essas coordenadas tempo-espaço (...) podemos ver novas relações espaçotempo sendo definidas em eventos tão diferentes quanto à teoria da relatividade de Einstein, as pinturas cubistas de Picasso e Braque, os trabalhos dos surrealistas e dadaístas, os experimentos com o tempo e a narrativa nos romances de Marcel Proust e James Joyce e o uso de técnicas de montagem nos primeiros filmes de Vertov e Eisenstein.
\end{abstract}

manter as vidas e as atividades do sujeito sob estrito controle e disciplina, produzindo assim um 'ser humano que possa ser tratado como um corpo dócil' (Dreyfus e Rabinow apud Hall,2000:42). 
$\mathrm{Na}$ conexão entre identidade e processo de representação proposta pelo autor, a moldagem e remoldagem de relações espaço-tempo no interior de diferentes sistemas de representação têm efeitos profundos sobre a forma como as identidades são localizadas e representadas. Hall afirma que as identidades se localizam num espaço e tempo simbólicos, e cita Edward Said, que ilustra esta idéia naquilo que chama de "geografias imaginárias" ${ }^{21}$ como sendo

suas 'paisagens' características, seu senso de 'lugar', de 'casa/lar', ou heimat, bem como suas localizações no tempo - nas tradições inventadas que ligam passado e presente, em mitos de origem que projetam o presente de volta ao passado, em narrativas de nação que conectam o indivíduo a eventos históricos nacionais mais amplos, mais importantes (idem, p.72).

Enfrenta-se uma profunda mudança de parâmetros. Esta frase resumiria facilmente uma série de contextos à nossa volta. A arte constitui, a partir do século $X X$, testemunho da complexidade social e política do fim do milênio. Vanguardas artísticas, artistas protagonizando movimentos, artistas protagonizando a si mesmos. A falta de parâmetros não é causa, antes efeito daquilo que há de mais real e contraditório no homem: sua identidade. Confusa, fragmentada, em busca de algo ou mesmo de nada mais. Não existem mais certezas, paráfrase a Prigogine. Talvez haja neste movimento a presença de um novo gérmen, o da verdadeira humanidade. Real, contraditória, sem respostas. Continuamente em busca.

Na cena artística do início do século XX, Picasso desconstrói suas senhoritas, ofertando uma estética quase profética do sujeito. Passados quase cem anos, a realidade televisiva nos dá conta do mesmo sujeito. O tempo encurtou seus espaços, desconstruindo e reconstruindo concomitantemente seu viver, seu pensar, seu agir. Mas a tecnologia e a suposta informação que guiam nossa vida presente não passam muitas vezes de acessório mal utilizado. Com a publicidade e a televisão, a máxima "uma imagem vale mais que mil palavras" é levada às últimas conseqüências em nossa sociedade de consumo. É a imagem quem dita

\footnotetext{
${ }^{21}$ Edward Said in: Hall, Stuart. A identidade cultural na pós-modernidade, 2001:71.
} 
as regras. O que vestimos, o que pensamos, aquilo que comunicamos. Como incluir no ensino de arte, na formação de professores de arte, as inquietações e questionamentos que fazem parte, no presente contexto, da compreensão da arte contemporânea?

Os tempos modernos contribuíram para visões entusiásticas de progresso, nem sempre alcançadas em seus projetos. Os tempos pós-modernos inicialmente trazem, no discurso arquitetônico, um novo estado cultural, "uma sociedade mais diversa, (...) menos carregada de expectativas em relação ao futuro" (Lipovetsky, 2004:51). No dizer de Lipovetsky (2004:51),

às visões entusiásticas do progresso histórico sucediam-se horizontes mais curtos, uma temporalidade dominada pelo precário e efêmero. Confundindo-se com a derrocada das construções voluntaristas do futuro e o concomitante triunfo das normas consumistas centradas na vida presente, o período pósmoderno indicava o advento de uma temporalidade social inédita, marcada pela primazia do aqui-agora.

Ao indicar a mudança de um foco no futuro para o aqui-agora, o autor continua esclarecendo o merecimento do termo pós-moderno:

O neologismo pós-moderno tinha um mérito: salientar uma mudança de direção, uma reorganização em profundidade do modo de funcionamento social e cultural das sociedades democráticas avançadas. Rápida expansão do consumo e da comunicação de massa; enfraquecimento das normas autoritárias e disciplinares; surto de individualização; consagração do hedonismo e do psicologismo; perda de fé no futuro revolucionário; descontentamento com as paixões políticas e as militâncias - era mesmo preciso dar um nome à enorme transformação que se desenrolava no palco das sociedades abastadas, livres do peso das grandes utopias futuristas da primeira modernidade (Idem).

Para o termo pós-moderno, que remete o olhar para um passado, Lipovetsky indica os tempos hipermodernos onde de uma modernidade consumada ainda mantemos o mercado, a eficiência técnica, o indivíduo. Realmente caminhou-se 
do pós ao hiper. Tudo parece estar desmesurado, sem limites. Hipervigilância, hipermercados, hipershoppings, hiperconsumo, hiperindividualismo.

Para o mesmo cenário, Calabrese faz uso do termo neobarroco indicando um novo movimento, uma nova temporalidade. A repetição, a ciclicidade, a variação organizada, o ritmo insensato, a irregularidade regulada fundamentam a estética contemporânea da repetição. O excesso, o romper limites, as extremas conseqüências, a tensão no limite fundamentam os saberes contemporâneos. Se há um cenário desestabilizador para a configuração de idéias, pensamentos, produções artísticas, retorno à questão, como incluir no ensino de arte, na formação de professores de arte, as inquietações e questionamentos que fazem parte da compreensão da arte contemporânea? Calabrese orienta uma possível resposta:

Creio verdadeiramente que a atividade crítica só pode fundar-se numa atividade interpretativa, a qual restitui um sentido de liberdade e de independência dos juízos de valor, o sentido de investigação da qualidade isenta de preconceitos, 0 sentido da aventura das idéias estéticas (Calabrese, 1987:209).

A reflexão estética, ao mesmo tempo em que provoca mudanças e questionamentos, nos induz ao movimento de identificação. Trabalhar a identidade sob o viés da estética cria possibilidade de ação, no ensino e na formação de professores, compatíveis com o próprio movimento da arte contemporânea.

Entretanto, a educação em suas experiências pedagógicas, ainda em situações de superar desigualdades, vive em seu sistema de ensino a "necessidade de explicação" (Ranciere, 2004:20-26). Para a arte depois das vanguardas não há explicação, ou haveria educação possível para essa arte? Entre as contingências da arte contemporânea e a necessidade de explicação da educação, quero chamar atenção para as questões de ambivalência, para a queda de alguns fundamentos. Pergunto: como os professores estão lidando com isso? 
Como afirma Kosko (1995) sabemos que as coisas mudam ${ }^{22}$. No cenário da multivalência em que vivemos é necessária uma aproximação. "As coisas, vistas de perto, se tornam confusas. Os limites não são exatos, as coisas coexistem com não coisas" (Kosko,1995:25). Lembrar esta afirmação é muito próprio, pois a discussão sobre a modernidade e a contemporaneidade, vistas de perto, é complexa, paradoxal, ambígua.

A existência simultânea de valores distintos ou contrastantes caracteriza a ambivalência. Penso ser este um dos entendimentos necessários para a compreensão do cenário contemporâneo, e principalmente para a atuação do indivíduo neste cenário. A presença singular do professor será definidora dos valores com os quais atuará neste cenário.

Será a ambivalência o termo que melhor expõe a contemporaneidade, justamente por seu caráter de simultaneidade, e ainda, por agregar ou manter o que há de valor moderno? Baumann (1999:12) afirma que

dentre a multiplicidade de tarefas impossíveis que a modernidade se atribuiu e que fizeram dela o que é, sobressai a da ordem (mais precisamente e de forma mais importante, a da ordem como tarefa). A ordem é o contrário do caos; este é o contrário daquela. Ordem e caos são gêmeos modernos. Foram concebidos em meio à ruptura e colapso do mundo ordenado de modo divino, que não conhecia a necessidade nem o acaso, um mundo que apenas era, sem pensar jamais em como ser. (...) esse mundo dificilmente poderia se reconhecer nas nossas descrições. Ele não compreenderia do que estamos falando. Não teria sobrevivido a tal compreensão. O momento da compreensão seria o sinal de sua morte iminente. E foi. Historicamente, essa compreensão foi o último suspiro do mundo agonizante e o primeiro grito da recém-nascida modernidade.

Pode-se pensar a modernidade como um tempo em que se reflete a ordem. Pode-se dizer que a existência é moderna na medida em que se bifurca em ordem e caos. "A existência é moderna na medida em que contém a alternativa da ordem e do caos", conclui Baumann (1999:14). Recordando o conto de Guimarães Rosa:

${ }^{22}$ Cf. o original "sabemos que las cosas cambian" e na continuação: "Las cosas, vistas de cerca, se vuelven borrosas. Los bordes no son exatos, las cosas coexisten con no cosas". 
ser moderno é estar na margem direita ou margem esquerda; ser contemporâneo é estar no leito do rio? Um breve suspiro: esta discussão dispensa abordar, não é a intenção, se o ensino de arte é moderno ou pós-moderno; ou quais os fundamentos, modernos ou pós-modernos, assumidos pelo professor em sua didática.

A luta pela ordem não é a luta de uma definição contra outra, de uma maneira de articular a realidade contra uma proposta concorrente. É a luta da determinação contra a ambigüidade, da precisão semântica contra a ambivalência, da transparência contra a obscuridade, da clareza contra a confusão (Baumann,1999:14).

E Baumann esclarece que se o outro da ordem não é uma outra ordem, mas o caos, orienta para a culminância que caracteriza o cenário pós-moderno.

A ordem como conceito, como visão, como propósito, só poderia ser concebida para o discernimento da ambivalência total, do acaso do caos. A ordem está continuamente engajada na guerra pela sobrevivência. O outro da ordem não é uma outra ordem: sua alternativa é o caos. O outro da ordem é o miasma do indeterminado e do imprevisível. O outro é incerteza, essa fonte e arquétipo de todo medo. Os topos do "outro da ordem" são: indefinibilidade, a incoerência, a incongruência, a incompatibilidade, a ilogicidade, a irracionalidade, a ambigüidade, a confusão, a incapacidade de decidir, a ambivalência (Baumann, 1999:15).

A ambivalência, confusão, perturbação, ambigüidade são o outro da ordem e caracterizam o pós-moderno.

Nascida sob o signo suspeito da ambigüidade, a questão pós-moderna é, simultaneamente, uma das mais difíceis tramas culturais da contemporaneidade e uma estrutura de complexidade cuja compreensão de raízes se afirma como das mais necessárias; de sua inteligibilidade depende, de certa forma, a inteligibilidade de desenvolvimentos e estruturas novas de mundo, aos quais os parâmetros da tradição não conseguem fazer justiça (Souza in Guinsburg e Barbosa, 2005:85).

Diante do que até aqui foi exposto, posso afirmar que o cenário contemporâneo para o ensino de arte vai sendo construído. O professor cria seu ato. As marcações da cena estão entre a arte que trabalha com o outro da ordem 
e da razão, e a educação/ensino, que historicamente trabalha com a ordem. Estar "entre" é estar no rio, nem margem direita nem esquerda, nem só arte nem só educação. Estar no leito do rio é o lugar da ambivalência, da arte, da simultaneidade necessária para a abertura isenta de preconceitos ao contemporâneo. Estar no leito do rio é o lugar que Paulo Freire recomendaria para romper com os contrastes popular e erudito, marginalizado e institucionalizado, rico e pobre, sucata e materiais artísticos? Estar no leito do rio é assumir um lugar onde as fronteiras perderam a relevância?

Ana Mae Barbosa ${ }^{23}$ na qualidade de curadora da Bienal Naifs do Brasil 2006 escreve que estar "entre" é "dissolução de territórios". Ao afirmar que aquela Bienal Naifs é uma exposição "da contaminação, da afirmação de diferentes testemunhos visuais comprometidos com a cultura do povo" (Barbosa, 2006:9) a curadora esclarece que:

Foram os primeiros modernistas que na sua guerra contra o academicismo atribuíram importância e deram visibilidade à arte da criança, dos loucos, dos índios, dos africanos e dos autodidatas, como códigos culturais construídos à margem dos valores dominantes. (...) Passado o período heróico do primeiro modernismo, chegamos ao alto modernismo, quando só valiam a Arte Abstrata, o Minimalismo e o Conceitualismo, que quanto mais hermético, mais poderoso. Tudo o que era popular se tornou indefensável. Reinava o repúdio à narrativa, à revelação do entorno do artista, e até a figura. Para atingir o ideal de 'autonomia absoluta da obra de arte', pregada por Clement Grinberg, era preciso abjurar referentes. (...) Hoje , a situação mudou. Na condição pósmoderna, o feminismo e o movimento de artistas afro-americanos responderam à exclusão que lhes impunham os círculos dos artistas com pedigree: retomaram a narrativa, agora engajada e de conotações críticas em relação á sociedade excludente (idem, 9-11)

E conclui Ana Mae:

Embora a muralha entre o erudito e o popular ainda perdure apesar de danificada pelo pós-modernismo, fica cada vez mais difícil separar os 'subextos' populares, separar a arte dita naif, da arte popular, da cultura visual do povo e da arte erudita que busca referentes populares. (Ibidem)

\footnotetext{
${ }^{23}$ Ana Mae Barbosa. Entre Culturas in: Naifs [entre culturas]. Bienal Naifs do Brasil. São Paulo:
} SESCSP, 2006. 
O movimento que percebo vai para longe das polaridades, é um movimento de conversação, de compreensão. No livro de Roger Clark publicado em 1996, Are education: issues in postmodernist pedagogy, esta mudança de paradigmas é analisada. $O$ autor demonstra que o cenário contemporâneo pode ser caracterizado como ambivalente e transitório porque existem movimentos contrários à objetividade, racionalidade e universalidade moderna. Com as reflexões e produções contemporâneas da arte esses movimentos produzem novos significados, concepções, dúvidas e perspectivas. Os significados são vistos como fluidos e contextuais.

As teorias modernistas têm sido substituídas por modelos conectivos que melhor refletem a multifacetada natureza da existência humana. $\mathrm{Na}$ arte, este novo sentido de conectividade tem resultado em uma rejeição das relações sujeito/objeto que tem historicamente existido entre artista/modelo e artista/espectador (Clark, 1996:2).

$\mathrm{Na}$ Arte/Educação contemporânea este sentido de conectividade aparece na retomada do conceito de arte como experiência. Ana Mae Barbosa informa:

Elaborado em 1934 por John Dewey, esse conceito circulou entre os pragmatistas e fenomenologistas com sucesso, mas não teve larga aceitação entre artistas e críticos de arte durante o alto modernismo. O pós-modernismo retoma o conceito embebendo-o em um contextualismo esclarecedor, que amplia a noção de experiência e lhe dá densidade cultural (Barbosa, 2005:11).

Neste aspecto Ana Mae Barbosa apresenta as aproximações entre Dewey e Paulo Freire: "Se, para Dewey, experiência é conhecimento, para Freire é a consciência da experiência que podemos chamar conhecimento" (Idem:12). E ainda, referindo-se a Dewey, Eisner e Freire, ela reconhece:

Novamente, os três gigantes da Filosofia da Educação se encontram e nos alertam acerca da importância da arte para nos permitir a tolerância à ambigüidade e a exploração de múltiplos sentidos e significações. Essa dubiedade da arte torna-a valiosa na educação. Em arte não há certo ou errado, mas sim o mais ou menos adequado, o mais ou menos significativo, o mais ou menos inventivo.

A arte na educação contrapõe-se às supostas verdades educacionais e às mais suspeitas ainda certezas da escola (Ibidem). 
Acredito que no cenário contemporâneo coexistem o moderno e o pósmoderno. No contexto local de muitos professores de arte se ensina em ordem cronológica um "desfile de estilos visuais" (Clark,1996:3). Cabe lembrar que considero que a ordem cronológica ou seqüencial de estilos, conteúdos e estudos não se apresentam como problemática no ensino de arte, a causa de dificuldades no processo ensino/aprendizagem está, sobretudo, presente na maneira mecânica como estas seqüências estariam sendo abordadas.

Projetos de ensino ainda desprezam gestos populares e a arte não-européia, valorizam os elementos formais e não alcançam múltiplas interpretações. Para que as imagens contribuam para atualizar professores e seus processos de ensino, neste cenário que se apresenta, será preciso entender que a arte não se diferencia da realidade, mas sim faz parte dela. 


\subsubsection{Arte plural}

Além das minhas imagens, quais perguntas trago comigo ao longo do percurso de constituição de professora de arte? Muitas. Algumas respondidas mais facilmente, são superadas; outras se transformam a cada nova experiência. Durante os últimos anos, acompanhando e orientando estagiários em suas práticas nas escolas, e juntamente, acompanhando a formação contínua dos professores em efetivo exercício da profissão, uma questão vem sendo protagonista. Diante das variações do panorama histórico, social, tecnológico, artístico, pergunto: é a própria arte hoje e o pensamento que ela provoca que forçam mudanças, e quais, no ensino de arte? Será preciso transpassar a porta do museu para a rua, da rua para o museu, da rua para a escola, da escola para a rua, para a casa, para tantas portas e janelas reais e virtuais.

Para desenvolver esta reflexão, penso ser necessário questionar a amplitude de mudanças do moderno ao pós-moderno, isto é, à atualidade da arte. O pósmodernismo, cenário contemporâneo, marca, entre outras coisas, os avanços da tecnologia, a diluição dos limites entre categorias artísticas, a mistura de procedimentos artísticos (desenho, gravura, pintura, escultura, cerâmica, fotografia, vídeo, podem estar híbridos na mesma produção), o diálogo entre diversidades e diferenças, todas as formas que abandonaram as grandes idéias, valores e instituições ocidentais calcados no pensamento racional da modernidade e em todas as formas modernas de existir. O recorte que segue é eloqüente sobre o que quero realçar.

Assistimos hoje a uma contestação teórica e prática de cada elemento do projeto iluminista de civilização: 1.No plano teórico, a partir de uma matriz nietzscheniano -heideggeriana, a ciência é vista como ideologia (Habermas) e como agente de um processo de dominação sobre a natureza e sobre os homens (Adorno e Horkheimer). A razão em geral, é uma simples antena na superfície do poder e uma indutora da docilidade social (Foucault). O irracionalismo se difunde nas atitudes e comportamentos sociais. Banidos pela ilustração, o mito e a superstição voltam triunfalmente (Rouanet, 1993:98). 
Prossegue Rouanet indicando um segundo elemento: o pensamento contemporâneo declara guerra ao sujeito (e cita Heidegger, Lacan, Foucault), "o que se traduz por uma guerra ao indivíduo que é solapado tanto pelo conformismo inerente à moderna sociedade de massas como pelas tentativas de reagir à massificação. Cada vez mais o mundo tenta remergulhar no coletivo" (1993:98). Este sujeito volta a buscar o comunitário, as raízes; um entendimento de holismo substitui o individualismo. Assim, alcança outro conceito, o "pluralismo", que Rouanet apresenta como terceiro elemento a quebrar o projeto iluminista.

3. A filosofia pós-moderna dissolve o universalismo iluminista em pluralismos linguageiros (Lyotard) e seus ideais pacifistas são desmascarados como manifestação de nilismo (Nietzsche via Deleuze). Também na prática o universalismo sucumbe ao particularismo. Desaparece a idéia de uma natureza humana comum, de destinatários comuns e de políticas destinadas a abolir os obstáculos à livre comunicação entre os homens. Voltam o racismo, o nacionalismo, o regionalismo, o tribalismo (Idem, idem).

Alguns sinais deste novo tempo, para Jameson (1991), existem de fato, entre eles os mais marcantes são a "fratura dos eixos" - estes eixos são as coordenadas, linhas de orientação da existência, a fratura significa o desaparecimento destes eixos. Na visão moderna, os indicadores foram: a razão, a história, o Estado, o saber da ciência. No pós-modernismo, verifica-se que a capacidade de orientação de tais elementos é uma ficção. A "visão do tempo": a modernidade possui a orientação para o futuro, pois é nele que está a sua realização. O pós-modernismo tem como referência o presente, pois the faltam a crença no passado e a expectativa no futuro. O "desaparecimento de fronteiras": os limites, contornos, fronteiras, entre saberes, sociedades e práticas sociais, tornam-se tênues ou desaparecem. A "liberdade de combinar": o moderno elegera um conjunto de combinações. O pós-modernismo verifica que as possibilidades de combinação são muito amplas. Pode-se citar também, segundo o mesmo autor, a retomada da consciência e da emoção, a valorização e liberação do corpo, a 
busca da diferenciação e da revolução do cotidiano, o prazer de viver o presente (Lins, 2001).

Nesse ambiente, os meios de comunicação de massa especulam sobre o real, transformando o mundo em espetáculo e alterando as expectativas e a sensibilidade dos indivíduos. A necessidade estética é suprimida pela imensa quantidade de signos inseridos no cotidiano, transformando as pessoas em receptores de signos criados para seduzi-los ao consumo. Nesse mundo padecese do desconforto ligado à percepção de que não há mais sentimento de coletividade, e de que as pessoas estão impotentes diante da complexidade dos problemas sociais. Daí a proeminência do individualismo, escorada na sensação segundo a qual, se não se pode salvar o mundo, pelo menos há que tentar salvar a si próprio. O coletivo está em minorias organizadas. É a fragmentação das idéias e das pessoas. É fato que o individualismo se fortaleceu com o modernismo (idem,2001).

O artista faz transbordar o seu lado pessoal, individual, numa linguagem própria, significativa, não tendo mais a preocupação de fazer inovações e de ser inédito. Faz apropriações, traz de volta o passado, retorna à figuração e ao homem, desfaz regras.

O pós-modernismo é eclético, não tem unidade e muda de facetas constantemente. Representa uma defesa do ser humano fragmentado e fragilizado por tanto bombardeio informativo. E quando se leva em consideração tais aspectos é que adquire significado especial o entendimento de que "o novo valor atribuído ao transitório, ao fugidio e ao efêmero, a própria celebração do dinamismo, revela um anseio por um presente estável, imaculado e não corrompido" (Habermas apud Harvey, 1989:291).

A arte se apresenta como um enorme mosaico de expressões. Pop, Minimal, Conceitual, Processo, Hiper-realismo, Land, Body, Happening, Vídeoarte, 
Multimídia. Os diversos estilos da arte do pós-modernismo convivem sem choques ou barreiras e foram se instaurando na década de 50, principalmente na década de 60 , quando ocorreram as mais consideráveis mudanças. É a partir dos anos 50 que a arte não mais se diferencia da realidade, mas sim faz parte dela. É importante enfatizar a pergunta que nos faz Arthur Danto (2006:39-40).

Para mim, a questão sobre o que a arte real e essencialmente é - em contraposição ao que ela aparentemente ou não intrinsecamente é - seria a forma errada assumida pela questão filosófica, e os pontos de vista que propus em vários ensaios sobre o fim da arte procuram sugerir qual deveria ser a forma real da pergunta. Como vejo, a forma da pergunta é: o que faz a diferença entre uma obra de arte e algo que não é uma obra de arte quando não se tem nenhuma diferença perceptual interessante entre elas? $O$ que me despertou para essa questão foi a exposição das esculturas de Brillo Box de Andy Warhol.

E continua:

Mas eu estava convencido de que eram arte e para mim a pergunta instigante e realmente profunda era no que consistia a diferença entre elas e as caixas de papelão de Brillo que poderiam ser encontradas no depósito dos supermercados, uma vez que nenhuma das diferenças entre elas pode explicar a diferença entre realidade e arte (Idem).

Desta forma, os tradicionais suportes são guardados, dando lugar a novas formas de expressão, e uma ampliação de limites associa música, teatro, dança, artes plásticas e literatura. A arte se instaura definitivamente tendo como principais características a mistura de materiais, de categorias ou de meios, a importância da construção conceitual e do processo de criação como parte inseparável da obra, até a impossível separação entre obra/espaço-tempo onde ela está e o indivíduo que por ali possa transitar. Com isso, o artista utiliza os materiais que lhe convêm, sejam eles orgânicos ou industriais, e a produção não se dá pronta ao público para contemplação, mas sim em processo em que a obra solicita a interação e reflexão. 
Nas questões relativas ao pós-modernismo, considero o pensamento de Arthur Danto (2006:28) quando analisa os conceitos da arte a partir do início da história da arte. Este autor refere-se ao historiador Hans Belting sobre a imagem antes da era da arte, segundo Belting, dos romanos até 1400 dC. Danto considera a arte depois do fim da arte, como se estivéssemos numa transição que questiona os valores estabelecidos e que nos joga num vazio. Danto expõe que o modernismo marcou um ponto na arte, antes do qual pintores se dedicavam à representação do mundo, pintando pessoas, paisagens, eventos, tal como se apresentavam ao olhar, época da representação do real. E ainda, no modernismo as condições da representação é que são a questão central, isto é, a arte é seu próprio tema. No mesmo livro, ele afirma que a distinção entre arte moderna e contemporânea não se esclareceu até os anos 70 e 80 , questionando que a arte contemporânea poderia haver sido por algum tempo a arte moderna produzida por nossos contemporâneos. Este termo mostra por si mesmo a relativa debilidade da nomeação contemporâneo como denominação de um estilo, por ser mais um termo temporal. Embora o termo pós-moderno seja forte, ele identifica, de acordo com Danto um aspecto da arte contemporânea. Para ele, pós-moderno seria apenas um estilo que podemos aprender a reconhecer, assim como podemos aprender a reconhecer estilos do barroco ou rococó. Todavia, adverte que "não existe uma arte mais verdadeira do que outra, bem como não há uma única forma que a arte necessariamente deva assumir: toda arte é igual e indiferentemente arte" (2006:38).

O pós-modernismo, deste modo, assumindo sua pluralidade ou adotando a idéia de que não existe uma arte mais verdadeira que outra, marca-se pela contradição, ambivalência ou novas e constantes rupturas.

Marcel Duchamp, em sua ruptura primeira ${ }^{24}$, deu origem a uma orientação que negou o espaço ordenado. Em Nu descendo uma escada, de 1912, a

${ }^{24}$ Chamo de ruptura primeira a obra Nu descendo uma escada, 1912, por considerar que habitualmente define-se a ruptura de Duchamp ao ato de encaminhar Fonte, 1917, para o Salão dos Arensberg em New York. 
perspectiva central da tradição é deslocada para um nu em estágios sobrepostos. Segundo Anne Cauquelin no meio moderno apresentaram-se diversos indícios que anteciparam os acontecimentos, conforme segue:

Realmente, se no domínio social e político as teorias algumas vezes se adiantam às práticas, no domínio da arte, em contrapartida, o movimento de ruptura está a cargo o mais das vezes de figuras singulares, de práticas, de fazeres, que primeiramente desarmonizam, mas que anunciam, de longe, uma nova realidade (Cauquelin, 2005:87).

A essas figuras que revelam os indícios de novos tempos, Cauquelin nomeia "embreantes" 25 Ainda segundo a autora, o "fenômeno Duchamp" é marcado pela crescente influência deste artista na arte contemporânea, referências, obras que Ihe são dedicadas, fato atribuído ao comportamento singular que corresponde às expectativas contemporâneas.

É importante destacar as atitudes de Duchamp, que segundo Cauquelin o coloca como embreante, pois tais posições anunciam o novo estado da arte. Cauquelin (Idem, p.90-1) apresenta quatro aspectos:

1. A distinção entre a esfera da arte e da estética. Estética designando o conteúdo das obras, o valor da obra em si; a arte sendo simplesmente uma esfera de atividades entre outras, sem que seu conteúdo particular seja precisado.

2. Na esfera da arte, considerando-a não mais dependente de uma estética; os papéis dos agentes não são mais estabelecidos como anteriormente. Produtores, intermediários e consumidores não podem mais ser distinguidos. Todos os papéis podem ser desempenhados ao mesmo tempo. O percurso de uma obra até o consumidor presumido não é mais linear, mas circular.

\footnotetext{
25 "O termo embreante designa, em lingüística, unidades que têm dupla função e duplo regime, que remetem ao enunciado (a mensagem, recebida no presente) e ao enunciador que a enunciou (anteriormente). Os pronomes pessoais considerados embreantes, pois ocupam um lugar determinado no enunciado, onde são tomados como elementos do código, além de manterem uma relação existencial com um elemento extralingüístico: o de fazer ato da palavra. (Roman Jakobson, 1963). Ao isolarmos aqui os 'embreantes', estamos fazendo referência a esses dois modos temporais: uma mensagem recebida no presente e seu enunciador - que foi seu autor -, e desse modo nos referimos à conexão que se operou entre passado e presente mas também ao jogo duplo dessas unidades colocadas no limite do objetivo (a mensagem enviada) e do subjetivo (a singularidade de quem anuncia)" (Anne Cauquelin, Arte contemporânea: uma introdução, 2005).
} 
Os dois primeiros pontos não eram compreensíveis no princípio, mas o foram ao longo de um processo onde houve, como terceiro aspecto: "Abandono dos movimentos de vanguarda e do romantismo da figura do 'artista'".

Em continuidade, apresenta:

4. Como a arte é um sistema de signos entre outros, a realidade desvelada por meio deles é construída pela linguagem, seu motor determinante. Importância dos jogos e da construção da realidade; a arte não é mais emoção, ela é pensada; o observador e o observado estão unidos por essa construção e dentro dela.

É bastante evidente que esses quatro pontos não eram perceptíveis logo de início. Eles entravam em conflito com o regime 'moderno' dominante e traziam em si uma carga de oposição pesada demais não somente para serem admitidos como percebidos (Idem, idem).

A citação é longa mas pertinente para afirmarmos o desdobramento desta pesquisa - a arte atual tem seu sentido consideravelmente alterado se percebida segundo o pensamento moderno. Seria como vivenciar e transformar a arte reflexiva de Duchamp na, por ele combatida, arte retiniana ${ }^{26}$ ? A atitude de Duchamp, em seus ready-made "não postula um valor novo: é um dardo contra o que chamamos valioso. É crítica ativa: um pontapé contra a obra de arte sentada em seu pedestal de adjetivos" (Paz, 2004:23).

Quando nas situações de ensino apresentam-se imagens, reproduções de obras, é preciso cuidado para que a obra e o artista não sejam novamente colocados em pedestais, ou o que seria pior, para que as reproduções não sejam apresentadas como obra. No que concerne à contemporaneidade, o que se adverte é que se precisa do entendimento das mudanças, aquelas apontadas por Cauquelin, que entraram em conflito com o moderno, anunciando uma crítica ao

\footnotetext{
${ }^{26}$ Cf. Calvin Tomkins em Duchamp, 2004: "Repetidas vezes nos últimos anos, Duchamp estaria falando desdenhosamente da arte 'retiniana', de uma arte cuja atração está centrada exclusivamente no sentido da vista. Foi Gustave Courbet, argumentava ele, que transformou a arte numa coisa retiniana; antes de Coubert, a arte havia atraído o intelecto de muitas maneiras diferentes, ensinando verdades morais ou religiosas e levando a mente em viagens imaginativas, mas o exemplo poderoso do realismo de Courbet havia varrido isso tudo - com conseqüências desastrosas. Bête comme um peintre foi um ditado na França durante toda a segunda metade do século XIX", queixava-se Duchamp, "e ele era bem expressão da verdade. O pintor que só põe na tela o que vê é um idiota" (p.68).
} 
gosto, à noção de obra, a princípios formais. É necessário também o entendimento de arte como pensamento.

Até este ponto apresentei algumas imagens do meu repertório e reflexões sobre arte e seu ensino, sobre leitura de imagens e leitura de mundo, sobre moderno e pós-moderno. Escrito assim até pode parecer que inconscientemente retomo a bipolaridade de conceitos modernos, porém o que enfatizo é que ao relatar a busca de imagens na aula de arte estive fundamentada numa necessidade de interrogar ações, conceitos, imagens, estereótipos. 


\section{BUSCANDO IMAGENS NA AULA DE ARTE}

A experiência contemporânea, após destituir a obra de arte de seu pedestal de adjetivos, nos conduz a manobras mais abertas, nos faz encaminhar reflexões para além de um ensinar a ler imagens ou ensinar arte contemporânea buscando conceitos e formulações determinadas.

A pesquisa realizada com professoras propõe refletir sobre a instituição de ensino que é moderna, sobre a arte contemporânea que rompe com instituições, sobre o susto e terror que a leitura de imagens contemporâneas provoca em alguns professores. Quando professores descobriram os conteúdos da arte, ou a própria arte para ser "lida" e ensinada conforme os princípios contemporâneos de ensino, encontraram também obras sem solução. Pergunto: o que poderia acontecer se assumíssemos a visão de que arte hoje se ensina a partir de experiências de impacto, de novidade? Quais serão as alianças do instante em que se encontram imagem, arte contemporânea e ensino?

$\mathrm{Na}$ arte e no seu ensino apresenta-se a dissolução de uma era em que as certezas ocupavam um lugar de honra. Se repassarmos os últimos trinta anos, o ensino de arte na educação escolar passou de habilidade técnica para expressão pessoal, e de expressão pessoal para aquisição de conteúdos específicos da área. Quando a partir da década de 90 estivemos firmes com a redescoberta das imagens para serem lidas e contextualizadas, descobrimos a dificuldade em lidar com a falta de critérios para a arte além das produções modernistas.

Para realizar a pesquisa defini como campo de investigação uma realidade que não fosse a dos grandes centros urbanos: a opção foi deixar o centro de Florianópolis e percorrer escolas distantes dos centros universitários, museus e instituições culturais. Na Rede Municipal de Ensino do município de São José foi desenvolvido o trabalho. Em diálogos, segundo Paulo Freire, recolhi informações, 
imagens e experiências. A pesquisa caracterizou-se como qualitativa, através de estudos bibliográficos apresentados nos capítulos anteriores e análise de resultados de questionário, entrevistas, grupo focal e imagens. Estes procedimentos compõem fontes para obtenção de informações a partir das quais se construirá a análise, pretendendo chegar a possíveis respostas às perguntas que foram formuladas nesta tese sobre as imagens na aula de arte.

\subsection{Percurso das conversações}

Concebendo a metodologia, num projeto de pesquisa, como um conjunto de procedimentos encaminhados para a averiguação de determinada disciplina e destinada à análise de investigação, procurei inicialmente desviar o olhar do habitual. Isto é, defini um campo para pesquisa onde ainda não havia sido estabelecido um contato com as escolas, onde os professores de arte não eram anteriormente conhecidos, e até mesmo o contexto diferenciava-se dos grandes centros urbanos.

Pesquisar é buscar saídas para problemas, é escolher caminhos para alcançar objetivos determinados; porém acreditando que uma metodologia não se faz somente por uma série de técnicas e instrumentos previamente elaborados, este trabalho foi sendo definido ao longo de seu percurso. Assim, destaco uma postura diante do ensinar e pesquisar:

Como em qualquer atividade humana, pesquisa enquanto processo não é somente fruto do racional; o que é racional é a consciência do desejo, a vontade e a predisposição para tal, não o processo da pesquisa em si, que intercala o racional e o intuitivo na busca comum de solucionar algo. Esses conceitos servem tanto para a ciência quanto para a arte, pois pesquisa é a vontade e a consciência de se encontrar soluções, para qualquer área do conhecimento humano (Zamboni, 1998:43). 
Acreditando numa "metodologia conscientizadora" (Freire,1987:97), fundamentada num processo dialético, optei por uma abordagem de conversação com e entre as professoras, conversação entre ensino e arte, e entre ensino e pesquisa, pois conforme aprendemos com Paulo Freire (1998:32),

ensinar exige pesquisa. Não há ensino sem pesquisa e pesquisa sem ensino Esses que-fazeres se encontram um no corpo do outro. Enquanto ensino continuo buscando, reprocurando. Ensino porque busco, porque indago e me indago. Pesquiso para constatar, constatando, intervenho, intervindo educo e me educo. Pesquiso para conhecer o que ainda não conheço e comunicar ou anunciar a novidade.

Assim, com o desejo de "conhecer o que não conheço" ${ }^{27}$ e com a motivação de anunciar mudanças, a pesquisa com professores de arte foi iniciada. Após momentos de conversação, a Coordenação de Ensino Fundamental da Secretaria Municipal de Educação do Município de São José ${ }^{28}$ convidou professores efetivos e colaboradores para participar de curso de atualização e revisão da proposta curricular da rede de ensino.

Nesse curso iniciei minha aproximação com os professores e procedimentos para obter dados. Os professores participariam por vontade própria, espontaneamente. A intenção foi realizar obtenção de dados em diferentes momentos com instrumentos distintos. Programei a aplicação de questionário previamente elaborado, constando de uma parte sobre dados pessoais e de formação, e outra com perguntas diretas, encadeadas sobre os temas da pesquisa. A escolha de questionário como instrumento de pesquisa foi realizada por acreditar que este instrumento agregaria maior número de informações, as quais serviriam como base para a formação dos grupos focais.

\footnotetext{
27 A opção por realizar a pesquisa em outro município deve-se ao fato de evitar limitar seu significado, uma vez que tenho contatos constantes por orientar estágios em escolas de Florianópolis e desenvolver projetos com professores.

${ }^{28}$ O município de São José é de colonização açoriana, conta com 173.239 habitantes, localiza-se nos limites de Florianópolis/SC. Caracteriza-se por ser uma área de produção industrial; a população que não trabalha na indústria desloca-se cotidianamente para Florianópolis, onde presta serviços ao comércio e setores da administração pública. Localiza-se na Grande Florianópolis, às margens da BR-101, com uma área de 114,7km2.
} 
Em 28 de fevereiro de 2007 compareceram 32 professores atuantes na área de arte dos 40 contratados pela Rede Municipal de Ensino. Novamente convidei os professores a participar da pesquisa, apenas 14 aceitaram responder ao questionário. Por reconhecer que somos sujeitos dialéticos, de acordo com Paulo Freire, na interação provocada pela ação inicial, percebi a necessidade de outra fonte de investigação. Vivenciei o sentido de provisoriedade, dinamismo e mudança, pois foi necessário mudar os planos levando em conta que dos 40 professores que atuam na rede municipal de ensino somente obtive dados de 14 profissionais: 12 mulheres e dois homens. Busquei complementar os dados obtidos por meio da aplicação de outro instrumento, entrevistas semi-estruturadas. Somente quatro professoras, dos 14 que inicialmente faziam parte do grupo, dispuseram-se a participar, uma vez que foi anunciado que as entrevistas seriam domiciliares e na escola. Minha intenção foi concretizada: entrevistar, observar e fotografar o ambiente familiar. Principalmente no aspecto de familiaridade com arte e outras imagens. Este cenário explicitaria as escolhas estéticas das professoras, entretanto sem estabelecer uma relação linear entre estas escolhas e o que elas denominam e apresentam como arte em sala de aula.

A entrevista semi-estruturada é uma técnica de coleta de dados que supõe uma conversação continuada entre informante e pesquisador, é uma opção teórico-metodológica. Conforme o andamento do processo, a entrevista cria possibilidade de que as informações sejam reorganizadas e o diálogo continue sendo feito até que o material para pesquisa seja consistente. As entrevistas permitem que, à medida que sejam identificadas categorias de análise, novas informações e indícios de novas perspectivas continuem sendo feitas ou se volte para elucidação.

As entrevistas semi-estruturadas foram realizadas com cada uma das quatro professoras em diferentes momentos. Elas foram ouvidas individualmente em sua escola, ocasião em que suas aulas foram observadas, e em sua residência. Neste caso, as entrevistas, que duraram de duas a quatro horas, aconteceram de modo 
a realmente possibilitar um encontro entre professoras de arte. Posso afirmar que cada entrevista foi, num sentido fenomenológico, "uma entrevista que se pauta no encontro entre seres-corpos-no-mundo, em que ambos, entrevistador e entrevistado se colocam à prova, já que o Eu encontra-se com o Outro, e ambos mudam suas vidas, de alguma maneira, após o encontro" (Melo, 2001:63). As questões abordadas nos encontros com as professoras permitiram evidenciar critérios para a escolha de imagens na aula de arte, bem como perceber imagens, objetos, arte e outros referenciais estéticos no âmbito domiciliar.

Como apenas quatro professoras aceitaram participar da entrevista, recuperei a intenção inicial do trabalho desenvolvendo a metodologia de grupo focal. A partir da disposição dos mesmos 14 professores que responderam ao questionário, apliquei o referido procedimento.

Grupo focal ${ }^{29}$, como meio de pesquisa, tem sido amplamente usado nas abordagens qualitativas. Trata-se de um grupo de pessoas selecionadas para discutir um tema do qual tenham experiência, por isto diz-se que é um grupo focalizado em uma atividade coletiva sobre um determinado assunto. Este assunto é introduzido através de questões específicas, ou através do uso de algum material, filme, texto, entre outros. Em sua dinâmica é importante a não diretividade e interferência do moderador, sua função será estimular a discussão entre os participantes. Um bom aproveitamento é gerado em grupos de oito a 12 participantes; habitualmente trabalha-se com mais de um grupo, selecionados segundo critérios de conteúdo, formação ou outros que atendam a especificidade da pesquisa.

Neste momento da pesquisa, foi realizado um encontro de quatro horas, numa escola do município; apenas um grupo foi formado, com 12 participantes. As professoras ${ }^{30}$ apresentaram uma multiplicidade de pontos de vista sobre imagens

\footnotetext{
${ }^{29}$ Cf. Bernadete Angelina Gatti, Grupo focal na pesquisa em Ciências Sociais e Humanas, 2005.

${ }^{30}$ Somente as professoras se apresentaram para participar do grupo focal.
} 
na aula de arte. A discussão do grupo foi gravada em áudio e posteriormente, após ser escutada repetidas vezes, foi também por mim analisada.

Ao longo desse processo o registro fotográfico foi constante, determinando mais uma fonte de dados para análise. As imagens produzidas durante os encontros com as professoras apresentam-se como conteúdo e como manancial de informações. Em uma pesquisa sobre imagens, as próprias imagens, originalmente como registro, passam a ser consideradas teor e matéria-prima.

Neste percurso de investigação, planejei utilizar questionário e grupo focal. Entretanto, utilizei como recurso de levantamento de dados: questionário, entrevista semi-estruturada, grupo focal e imagens, algumas das quais fazem parte do corpo deste trabalho.

\subsection{Diálogos sobre imagens}

As imagens são textos visuais, mas neste estudo apresenta-se também um texto narrativo verbal, capaz de proporcionar novo encontro com as professoras. É fundamentado nos diálogos, os quais foram marcantes pela experiência de não buscar apenas palavras nas entrevistas. Mas reconhecendo que "a nossa visão está em constante atividade, sempre em movimento, sempre captando coisas num círculo à sua volta, constituindo aquilo que nos é presente, tal como somos" (Berger, 1972:13), busquei ouvir as palavras e perceber o contexto no qual elas se originaram. Assim, considerei, para efeitos desta pesquisa, o ambiente familiar das professoras, os seus livros de referência, os fatos marcantes que relataram, sua própria seleção de objetos de uso cotidiano e seleção de imagens para as aulas e para a sua residência. 
Com estes diálogos sobre imagens pretendo demonstrar o movimento dialógico, segundo Paulo Freire, ao serem lidas palavras, imagens e o mundo das professoras. Ainda citando Berger (1972:13):

Pouco depois de se adquirir a faculdade de ver, apercebemo-nos de que também podemos ser vistos. Os olhos do outro combinam-se com os nossos para tornar completamente crível que fazemos parte do mundo visível. Se aceitamos que podemos ver aquela colina, postulamos que daquela colina podemos ser vistos. A natureza recíproca da visão é mais fundamental que a do diálogo falado. Muitas vezes até, o diálogo é uma tentativa de verbalizar isso mesmo - uma tentativa de explicar como, metafórica ou literalmente, 'se vêem as coisas' e uma tentativa para descobrir como 'o outro as vê'.

Ao relatarem aspectos de sua vida, as professoras viram-se como profissionais, ao mostrarem materiais e recursos de ensino encontraram-se com pessoas capazes de viver conscientemente sua autonomia e suas escolhas. As professoras, ao se tornarem instrumentos para a autonomia de seus alunos, tornam-se anteriormente fonte de encontros com os âmbitos da realidade em busca da própria autonomia (Quintás, 1992:14). Criando respostas criativas e novas possibilidades a partir de um contexto apresentado, agem sobre as coisas e atuam para melhor resolver situações do seu meio social.

A estética pode desempenhar um papel decisivo nesta difícil tarefa pedagógica. Se se analisar com finura metodológica a articulação interna da experiência artística, descobre-se nela uma trama fecunda de apelações e respostas, e se advinha o nexo que existe entre a entrega a instâncias valiosas e o ascenso ao melhor de si mesmo. Este nexo e aquela trama constituem também os dois pilares da experiência ética e religiosa (Idem, p.16).

Uma das maiores urgências da nossa sociedade é a formação ética, para isto é necessário recuperar a totalidade do humano na educação, é preciso pensar na totalidade das experiências vividas, além de um pensar em conteúdos e currículos. Qualquer ensino que não chegue mediante uma pedagogia da experiência, do diálogo, parece negar as escolhas, encontros e descobertas do humano envolvido neste processo. As escolhas das professoras, escolhas estéticas intimamente ligadas à "experiência-vida" (Dewey,1974:184), estão conectadas ao vínculo entre o ético, o estético e o pedagógico. Isto se faz por uma 
"articulação interna do processo de imersão do homem numa realidade valiosa. A descoberta desta lógica lança torrentes de luz sobre o sentido das ações e dos hábitos do homem. Na mesma medida, constitui uma chave decisiva de formação" (Quintás, 1992:25).

Em todas as manifestações das professoras, seja em grupo ou individualmente nas entrevistas domiciliares, evidenciam-se modos de ser nos fatos que descrevem, assim como tornam-se visíveis suas concepções sobre arte, educação e vida ao relatarem sobre suas práticas educativas. Neste aspecto, é relevante a afirmação de Ana Claudia Oliveira (2005:116):

Pelas escolhas didáticas para a operacionalização dos conteúdos e dos instrumentos metodológicos para ministrá-los, o professor também põe em circulação, na sala de aula, simulacros das suas concepções de mundo, de suas crenças e valores. Em outras palavras, o professor se expõe visualmente, fazendo-se visto. A ele mesmo, a compreensão de suas estratégias de visibilidade é uma cognição relevante.

Sob este enfoque revelaram-se idéias, imagens, procedimentos de ensino, experiências de vida, frustrações, competências, necessidades, sonhos. O objetivo aqui não é de apresentar dados, mas como escreve Regina Machado (2004:10):

o objetivo é propiciar uma experiência de leitura que não apele apenas para o raciocínio lógico. Dirijo palavras e imagens poéticas a pessoas que possam pensar, sentir, imaginar, perceber e intuir o que está no texto e nos intervalos de respiração do discurso. Proponho uma conversa ressonante, em que imagens internas, questões, lembranças e outros fatores que compõem a experiência de vida dos leitores sejam convidados a participar ativamente da leitura.

Assim, faz-se um convite para participar dos diálogos.

A professora, mostrando as fotografias emolduradas na parede da sala do apartamento, conta: 
Este é meu filho e a namorada, minha mãe, a turma do Colégio, adoro estas fotos. Este quadro minha filha pintou. Ana Laura tinha uns quatro anos. Olha o tamanho da mão, ela me retratou e me presenteou no dia das mães. Aqui eu coloco o que eu gosto, o que eu quero ver.

Em sua casa a professora expõe nas paredes o que gosta e quer ver; na escola, apresenta aos alunos imagens determinadas pelos conteúdos programados. Então explica seus procedimentos:

Na escola, a primeira coisa que eu vejo é o conteúdo da história da arte ou o artista que eu vou abordar. Aí eu vejo o que poderia ser interessante para aquelas crianças. Por exemplo: se vou trabalhar Leonardo da Vinci, eu tenho que primeiro mostrar a Mona Lisa, eles têm mais intimidade, eles já conhecem, depois disso é que eu vou partindo para mostrar outros. E assim também algo que eu possa trazer para perto deles. Vou trabalhar Van Gogh, começo pelo quarto ou pelo auto-retrato sem orelha. Na verdade eu não sinto assim... muito entusiasmo dos alunos pelas imagens. Eu busco alguma que tenha uma curiosidade ou que eu possa abordar de maneira diferente. Primeiro chamo a atenção deles com a imagem, pra depois falar.

Ao comentar que não percebe entusiasmo dos alunos, explica em seguida o que mais os atrai:

As imagens que eles mais se entusiasmam é pelo que é do mundo deles, do dia a dia deles: Bob esponja, Os Rebeldes, videoclipes, pôsteres, revistas. Aí fica difícil... Às vezes eu faço esta troca, vamos fazendo uns engates para chamar atenção. Mas eu não sinto aquela empolgação. Eu acho que eles fazem por obrigação, porque é conteúdo. Não sinto muito interesse. $E$ raro. $A$ imagem que a gente leva e que eles podem fazer uma transformação. Eles começam a se ater aos detalhes para poder fazer uma leitura.

Logo em seguida a professora fala sobre a condição das imagens:

Mas, e a qualidade que a gente também não tem, né? Não tem dinheiro sobrando para comprar, mal a gente consegue as imagens da Revista Caras. Teve uma promoção então comprei alguma coisa. De livros, eu tenho aquele que ganhei de uma amiga.

Neste momento a professora abaixa-se e procura algo dentro de um armário ao lado da geladeira. Instantes depois se levanta com um grande livro de capa azul nas mãos. O livro que a amiga deu, por não querer mais, é repleto de 
imagens de artistas reconhecidos ao longo da história da arte. São imagens de aproximadamente $50 \mathrm{~cm} \times 35 \mathrm{~cm}$, em boa qualidade de impressão, que representam obras de artistas do Renascimento ao Moderno. Na parte final do livro estão 20 reproduções de gravuras japonesas. Ao expor sobre os materiais que ganha, volta a falar sobre a dificuldade em ter imagens com boa qualidade:

Eu ganho bastante material de outros professores, eles mandam pra mim, a gente troca bastante. Senão... Eu fiz uma apostila agora, aí tiro as imagens da internet, mas eu digo pros alunos: - Olha aqui está azul, mas o original não é azul, é que a tinta era pouca e a impressora não era boa. Então a qualidade já não chama atenção, imagens muito pequenas, grandes não. Agora é que está tendo tecnologia para levar imagens em DVD para a escola.

E tão logo a professora aponta o uso de DVD como solução para ter imagens em bom tamanho e com qualidade, apresenta outra dificuldade:

Mas aí, só pode usar o DVD uma vez por semana, ou uma coisa ou outra, ou outra turma está usando. Imagina: 50 alunos de uma sala vão até lá embaixo na sala de vídeo, aí acomoda todo mundo, bota imagem, começa, já não dá tempo pra muito papo, é hora de ir embora de novo. É complicado trabalhar com imagem, é muito complicado. Aliás, ultimamente está complicado trabalhar com qualquer coisa...Tem salas que eu não consigo trabalhar práticas, as $5^{a}$ séries, por exemplo são 49 alunos, é inviável, não existe possibilidade, nas $8^{\underline{a}}$ séries é uma aula por semana, nas $5^{\underline{a}}$ e $6^{\underline{a}}$ série são duas aulas de 45 minutos, se alguém souber uma possibilidade eu gostaria de aprender.

O encontro no apartamento desta professora durou quatro horas, entre falas espontâneas e respostas dirigidas, percorreu-se da sala-cozinha até o quarto onde está seu computador. Muitos dos seus projetos estão registrados, com trabalhos dos alunos, planejamento e relatório. Sobre o armário do quarto encontram-se caixas grandes onde há muito material guardado para uso em aula. Sobre os materiais a professora comenta:

São 17 anos carregando sacola. As professoras de arte são sacoleiras. Quando era PPT [Preparação Para o Trabalho] eu carregava martelo, prego, lixa, tocos de madeira e outros materiais. Agora que sou da arte carrego carrinho, desses de feira, por que se não levar material eles não vão fazer 
nada; chega uma hora que tu cansas, não sei mais o que fazer e aí? Vou fazer o quê?

Embora a professora, quase em desabafo, pergunte "Vou fazer o quê?", desenvolve suas estratégias e cria constantemente materiais didáticos e jogos, inova suas ações ao produzir pequenas edições gravadas em CD, os quais são resultados de suas pesquisas, em internet, guiadas por suas escolhas.

Outra professora, em entrevista domiciliar, afirma que mostra para seus alunos reproduções de obras, fotografias e trabalhos dos próprios alunos:

Uso tudo o que posso e que está ao meu alcance, as reproduções da arte mais conhecida é o mais fácil, mas o tamanho das imagens... gostaria de trabalhar com imagens grandes para que os alunos pudessem visualizar todos os detalhes. Se as imagens estão nos livros, também a reprodução é um obstáculo pelo custo da cópia colorida.

Nas transcrições da discussão entre as professoras que participaram do grupo focal encontram-se algumas possibilidades de respostas. Segue um trecho da discussão:

- Eu acho que o princípio fundamental na nossa área é a imagem, só que com a diversidade de imagens e recursos... Tem uma questão que é fundamental, que não é a Proposta Curricular ou os conteúdos que vão dar a resposta, mas é a formação, é o que eu professora escolho.

- É ter mais de uma opção e liberdade e coragem.

- Buscar opções é escolher o que nós vamos trabalhar, com quem, por exemplo: como professora escolho o conteúdo, temos opções, mesmo sem saber com quem nós vamos trabalhar, mesmo sem conhecer o aluno nós já chegamos com alguma coisa escolhida para cada turma.

- Selecionar, no caso aqui, nós que temos um conteúdo tão vasto, é muito complexo. O que eu preciso para escolher?

- Tenho que ter uma atitude livre, quando escolho me sinto livre para selecionar o que me agrada ou não.

- Mas eu posso priorizar. Não é o que agrada que vou trabalhar, é o que se adapte à gente, a gente tem prioridades. 
- Quais as escolhas mais importantes que você já fez?

- São de caráter pessoal e não de conteúdo para aula.

Entre exclamações de todas, e algum momento de silêncio, a conversa continua:

- A minha escolha mais importante, até hoje, foi o vestibular...

Antes que a professora continuasse a falar, foi interrompida por outra:

- A minha mais importante foi ter ido para a aldeia com os índios. Eu estava deixando tudo para traz e...

- Então foste tu que deste aula no Rosinha Campos?

- Sim.

- Foi a tua marca que ficou. Eles [os alunos] ficaram falando que a professora do ano passado só queria falar sobre índios.

- Sim, foi há anos atrás. E no ano passado que eu dei aula no Rosinha. Eu fiz uma escolha na minha vida, e tudo que eu dava na sala de aula eu puxava aquela experiência.

- Eu não critiquei, só perguntei...

- A gente pergunta o que eles tiveram no ano anterior em arte, como eram as aulas de arte.

- Eu anoto tudo dos anos anteriores, às vezes vou nos meus cadernos dar uma olhada para ver o que vou fazer.

A discussão se encaminha para seleção de conteúdos, percebe-se como as professoras procedem para evitar repetir assuntos e fazeres já conhecidos dos alunos, do mesmo modo evidencia-se a dificuldade em organizar uma seqüência curricular. O diálogo continua sobre as experiências marcantes das professoras e suas contribuições para as aulas:

- Este teu contato com os índios marcou para os alunos...

- A Direção me abordou como se fosse uma coisa pejorativa. Puxa!...Mas... A sala de aula é o único espaço que eu tenho... é para enriquecer um pouco o 
conteúdo de aula, os índios só têm coisas boas para nos ensinar. $E$ aí, nisso eu ouvi: "Professora, os alunos estão reclamando que a senhora fala demais em índios." Eu só quero enriquecer um pouco o espaço cultural deles.

- Teve um professor que veio da Bahia e só falava na Bahia.

- Eu acho que se é tua experiência, tem que falar.

- Se eu acabei de ver uma obra, um espetáculo, é claro que eu quero falar daquilo.

Nestes diálogos percebem-se, também, as formas de registro de aulas e projetos. Discutem-se diferentes entendimentos de conteúdo, abrangência dos conteúdos das artes visuais, conteúdo como teorizações e controle disciplinador. Em vários momentos, no grupo focal, as professoras abordam questões espontaneamente, porém as respostas nem sempre são diretas:

- Como você escolhe as imagens para a sua aula?

- Depende...

- Eu acho que tem professor que só dá conteúdo, como tem muito professor que só dá Van Gogh, vai lá e escreve no quadro tudo sobre Van Gogh, só porque não dá conta da sala de aula, uma outra coisa é mostrar a imagem.

Os diálogos em alguns momentos tornam-se longos depoimentos sobre fatos escolares, situações consideradas pelas professoras como bem-sucedidas ou discriminações sobre as aulas de arte:

- Ah... hoje de manhã na escola uma colega falou assim: - Bonitos aqueles trabalhos que a turma da $8^{\underline{a}}$ está fazendo em artes, além disso mantêm eles ocupados porque aquela turma é difícil.

- A escola hoje...

- Eu não sei, mas acho que isso tudo aí, a culpa é do professor...

- Culpa?

- Tem professor, hum... me desculpem, mas, eu conheço lá no meu colégio... tem professor que só vai passando a folha pro aluno desenhar e fica lá sentado. Cá entre nós, tem. 
Outra professora intervém possivelmente com intenção de trazer a discussão para a pergunta:

- Se ela dissesse assim: "- Eu não uso imagens". O que você diria para ela?

- Está bloqueada! Vai buscar maneiras de ensinar. Eu acho que este é o papel do professor de arte.

Sobre a seleção de imagens, os questionários utilizados na pesquisa indicaram uma predominância de respostas onde a história da arte em cronologia e linearidade é determinante. Algumas respostas:

- Eu me baseio no conteúdo das imagens, na época histórica, na projeção do artista e sua relevância na História da arte.

- Observo o gosto dos alunos, mostro o que foi feito na evolução da história.

- Seleciono as imagens da arte de acordo com o período estudado.

- Escolho as obras que tenham clareza do período que está sendo estudado.

- Eu pego as reproduções conforme o período histórico que estou trabalhando.

- Gosto de selecionar as imagens da arte pelo período histórico trabalhado, as que eu penso que são mais atrativas para o aluno.

- Seleciono conforme os períodos a serem trabalhados, mas sempre procuro distorcer... ou melhor, mudar.

E retornando para as discussões no grupo focal, na questão sobre escolher imagens, as professoras continuam:

- E tu, como tu escolhes?

- Depende do conteúdo programático. Daí eu procuro...

- Eu sempre gostei, desde menina, de guardar figuras. Antes de ser professora eu já tinha muita coisa.

Ao ser interrompida antes que concluísse, a professora só voltou a falar bem mais tarde, dizendo:

- Neste semestre eu estou fazendo uma coisa bem interessante, eu estou colaborando com eles na questão de como se olha... estou aproveitando o conhecimento que eles têm dos elementos visuais. Mas... eu me queixei para eles de uma coisa muito difícil para mim: o acesso às reproduções. E uma 
menina, que tem mais dificuldades... ela me emocionou... ela vem todo esse semestre com imagens que ela encontra, ela recorta de revistas. Então, assim... quando eu não tenho mapeada uma imagem eu dou caminhos para eles buscarem, aceito e converso sobre tudo o que eles trazem.

Percebe-se que as professoras de arte deste campo de pesquisa estão realmente distantes dos materiais de ação educativa produzidos por museus e outras instituições culturais.

Nas entrevistas domiciliares, encontraram-se outras respostas e uma única vez foi citado o material de uma exposição:

Eu uso as imagens que eu tenho, este é meu critério, como é que eu vou usar uma coisa que não tenho? As imagens que eu tenho vão desde... o que eu menos tenho são reproduções de obras contemporâneas, porque é uma dificuldade ter essas imagens em livros. Tenho alguma coisa da Bienal de São Paulo, mas também são só aquelas, não tenho sobre artistas, ou sobre outros contextos, aí eu fico com aquilo que eu tenho... mas... sempre procuro...mas fico mesmo com o que tenho. Daí, seleciono aquilo que eu acho que dá para estar trabalhando na sala de aula.

Sobre a presença da arte contemporânea nos projetos de ensino, os questionários contribuíram para mostrar algumas dificuldades. Duas professoras demonstraram a própria insegurança em abordar esta temática dizendo não dominar o assunto: - Não domino. - Não tenho muito conhecimento. Em outras respostas o motivo para não introduzir assuntos referentes à contemporaneidade da arte é desviado para os alunos, conforme as respostas que seguem:

- Apresento imagens da arte contemporânea com pouca freqüência pela dificuldade em ter material e também dificuldade de aceitação pelos alunos.

- Uso a arte contemporânea em aula timidamente ainda, porque acho importante o contato com o que se produz hoje em arte, embora seja muito difícil eles compreenderem como arte o que é contemporâneo.

Em entrevista uma das professoras diz apresentar imagens do que está sendo produzido atualmente: 
Mostro para que os alunos conheçam o que se faz hoje, porém existe a dificuldade de acesso a tais imagens, assim como conhecer o trabalho do artista, a trajetória dele... só nos catálogos, que não são distribuídos gratuitamente. Mas artistas contemporâneos são os que produzem atualmente? Segundo Ana Mae, Velásquez é contemporâneo. Então, é difícil classificar. Já usei reproduções do Carlos Asp, mas falamos de cor, forma...

Esta professora demonstra interesse em ir além das imagens apresentadas pela história da arte, busca atualização em catálogos da produção mais recente e assume um posicionamento de quem faz leituras e reflexões sobre os conteúdos da arte e seu ensino. Quando cita Ana Mae ${ }^{31}$ sobre Velásquez mostra que faz discussões sobre o que é contemporâneo, aborda o contexto do apreciador como fator de contemporaneidade. Quando diz já ter usado reproduções de Carlos Asp ${ }^{32}$ demonstra uma insatisfação por ter abordado aspectos da linguagem visual, negando a contemporaneidade dos conceitos e contexto do artista.

Outro aspecto que pode ser evidenciado na fala da professora é a dificuldade de acesso às imagens. No grupo focal os obstáculos mais evidenciados são: tamanho, qualidade, custo e acervo escolar. A pesquisa identificou que as imagens utilizadas pelas professoras são de seus próprios acervos.

- A escassez de imagens em tamanho adequado, a escassez de recursos para as suas reproduções.

- O pior é o tamanho, depois a qualidade.

- As salas de aula são grandes e muitas imagens não são grandes. É preciso passar as figuras de carteira em carteira.

- Eu possuo bastante material de imagem, o contemporâneo é que é mais difícil de encontrar.

- Se as reproduções estão em livros a dificuldade é a cópia, se as reproduções das obras foram selecionadas na internet a dificuldade é a impressão.

- Não encontro coisas boas nos sebos, o custo não favorece a reprodução e não há materiais acessíveis na prefeitura e nas escolas, fico frustrada por muitas vezes não poder mostrar o que gostaria.

- Não existe na escola a documentação necessária.

- Falta de recurso didático nas unidades escolares.

\footnotetext{
${ }^{31}$ Ref a palestra proferida por Ana Mae Barbosa no Congresso da Federação de Arte Educadores do Brasil - CONFAEB, realizado em Florianópolis, em 2006.

${ }^{32}$ Artista plástico natural do Rio Grande do Sul, residente em Florianópolis.
} 
Outra professora quase sussurrou ao dizer:

- Eu pego o próprio livro didático, um livro antigo que tem na biblioteca, com as figuras pequenininhas, mostro ali na frente, vou passando, um por um vai olhando e é assim.

Considero relevante, demonstrando abertura de possibilidades de ampliação de repertório e conhecimento, a fala da professora que afirmou:

- Minha dificuldade é querer encontrar o que não é comum nos livros de arte e nos sites.

Um breve silencio no grupo focal foi interrompido quando se ouviu:

- Mas... por que temos que usar imagens na aula?

Ao ouvirem esta fala, várias professoras falam ao mesmo tempo, gerando alguma dificuldade em transcrever o que foi dito, identifico expressões como:

- ...é fundamental...

-...porque dá entendimento...

-...arte é através do que vê...

-...é um luxo...

- Como? Parem, parem...

- Vocês ouviram isto? É um luxo?

A professora diante do silêncio que se impôs explica-se, gerando um diálogo com outra participante, que faz um depoimento:

- É porque é um luxo mesmo, dá trabalho, a gente tem que pegar e trazer o que for mostrar, é tão fácil conseguir imagens na internet, na biblioteca, é fácil abordar a história da arte, mas... eu digo... para ter qualidade... é luxo.

- Eu tenho muitas imagens, minhas imagens são lindas. Tenho Renoir, Picasso, Tarsila, Volpi, tenho um monte, mais de cinqüenta. Sabe o que eu faço? Quando chego coloco tudo na parede, também no chão. Aí eu pego e mando um aluno escolher uma, aí ele escolheu e eu pergunto por quê. Ele vai falando...falando. Às vezes também pego um papel e recorto uma janela, não sei se estou errada, mas daí ele vai olhando detalhes. Ele pode reproduzir ou fazer outra figura para completar. É assim que vou trabalhando com eles. 
- É isso que quero dizer, dá trabalho... pegar a imagem e ver o que vai dar para fazer...

- Deixa eu falar mais um pouquinho. Eu fiz uma besteira na minha vida, não sei se foi bobagem ou castigo. É sério. Eu era professora efetiva no Estado, por quase 20 anos, queria mais. Tirei uma licença sem vencimentos. Mas eu tinha um processo administrativo por causa da APP [Associação de Pais e Professores]. O que aconteceu: eu me mandei para os Estados Unidos, ganhar por dia e em dólar, mas...não foi normal, atravessei rio, uma noite inteirinha...

- Como naquela novela?

- Passei o maior dos trabalhos da minha vida. Quando cheguei dentro dos EUA, eu era bem tímida, não sou de falar, mas o que aconteceu quando cheguei nos Estados Unidos? Fiquei presa. Com chip nas minhas pernas, fiquei presa por quatro meses. E agora? Na educação, a Secretaria de Educação não aceitou minha licença. Situação difícil. Fui demitida por 'indisciplinar', é que não fui na audiência da APP, enquanto isso eu estava presa lá. Quando fui mandada pra cá, cheguei aqui e perdi tudo, passei fome. Até que consegui trabalhar, essa aulinha aqui no município e arranjei advogado e provei o erro do contador da APP. Com a Graça de Deus fui reintegrada no Estado. To lutando...

- O que isso tem com as imagens lindas?

- Ah!...são pranchas assim grandes...lindas...Lá, presa, eu fiquei muito mal, mas lá eu fazia umas oficinas de integração, nas oficinas falei sobre meu interesse em arte, visitei sites de museus e eu consegui tudo o que eu trouxe pra cá.

- É uma ilusão, mas valeram tuas figuras.

Nas entrevistas e diálogos do grupo focal os fatos relatados são muitos, histórias pessoais e profissionais. Um outro momento que merece ser destacado é a discussão entre as professoras sobre a quantidade de imagens que nos solicitam no cotidiano. Esta discussão surgiu em decorrência do questionamento que as professoras fizeram sobre quais imagens devem ser mostradas aos alunos em aula, por considerarem representativas da história da arte, e a relação com o excesso de imagens que eles já vêem no dia-a-dia.

- No ano passado, eu passei um dia e disse: olha o tanto de informação que tem aqui perto, vocês já repararam que toda semana a dona da loja ao lado muda a vitrine? Aí eu comecei a pontuar algumas coisas... eles não tinham reparado...nossa! Eu estava lendo um texto, vocês já repararam como nos protegemos de tanta informação, de tanta propaganda? 
- Olha só, eu fiz um curso sobre cinema e uma das coisas que a gente estava levantando era essa proteção mesmo. Já pensou se nós fossemos nos ater a todas as informações? Iríamos bater o carro, não ver nada...

- Por que umas imagens ficam mais marcadas, chamam mais atenção que outras?

- Por causa das nossas histórias...

Neste instante fez-se longo silêncio, como se nada mais pudesse ser dito. Até que uma professora reinicia a discussão, novamente questionando sobre as escolhas das professoras.

- Quais os efeitos das nossas escolhas?

- Acho que a gente nunca tem certeza dos efeitos...

- Em aula acho que a gente pode trazer muita participação ou um desastre...uma situação complicada...

- Eu acho que nunca uma imagem vai te levar a uma situação complicada...

- Como assim...

- Eu acho que algumas vezes, chega uma hora que você sempre precisa de algo mais e você não consegue esgotar o assunto e se torna repetitivo, não no sentido de falar sobre uma coisa mas, assim oh... Uma vez estava trabalhando sobre um artista, os alunos diziam :- Lá vem ela falar de fulano de tal. Ou passavam no corredor e perguntavam: - Professora, como vai fulano?

Entre muitos risos, todas falam ao mesmo tempo, até que se distingue:

-...é também tem isso, quantas vezes eles já ouviram falar de um artista e se repetem as mesmas coisas.

- De toda maneira a gente sempre aborda diferente.

- Acontece que quando a gente inicia, todo mundo vai falar de linha, ponto, cor, plano, textura...

- Eu não falo mais sobre isso.

- Não obrigatoriamente. 
- A grande maioria faz assim e os alunos principalmente da $6^{\underline{a}}$, $7^{a}$ e $8^{\underline{a}}$ dizem que já viram, mas depois a gente vai conversar com eles e eles dizem que não foi bem assim.

- Teve uma escola em que eu trabalhei no Paraná, logo depois que voltei da aldeia, e os índios usavam muitos adornos e faziam muitas coisas, trouxe muita coisa de lá, muitas mantas, aí tinha uma aluna que me chamava de vendedora de tapetes. Eles nos vêem de acordo com o que a gente mostra...

As professoras conversam entre si e ao ouvirem-se, escutam-se a si próprias, vêem-se a si próprias, percebem seus sentimentos e idéias.

\subsection{Imagens do contexto}

As imagens que apresento neste capítulo não fazem parte daquele acervo de memórias que vem sendo citado neste trabalho, porém reconheço que algumas delas poderão vir a fazer parte. São fotografias. Apresento-as como decorrência da produção da pesquisa. Neste capítulo dialogo com imagens fotográficas produzidas a partir do contexto escolar, campo de pesquisa, atribuo significados a elas e destaco os elementos, pessoas, objetos que sob minha análise se evidenciam como elementos punctum, os pontos que pungem meu olhar.

Conforme apresentamos no início deste trabalho, as imagens correspondem a uma escolha pessoal, um singular modo de ver e de dar a ver o ensino de arte. São também uma representação visual correspondente aos meios da arte. Durante todo o processo de acompanhamento das professoras em entrevistas domiciliares ou em escolas, estive presente no cenário - mais do que informações em palavras, trouxe um fragmento do real visível.

Lembro também que na introdução deste trabalho enunciei que as fotografias seriam apreciadas segundo os conceitos studium e punctum de Roland Barthes, e segundo os critérios de avaliação de uma proposta de Arts-Based Educational 
Research - iluminating effect, generativity, incisiveness, generalizability. Neste capítulo estes conceitos são apresentados, orientados pelo entendimento de "conscientização" de Paulo Freire já desenvolvido no subtítulo Leitura de mundo: a estética em Paulo Freire. A conscientização diante das fotografias permitirá que sejam analisadas ultrapassando um nível de espontânea apreensão da realidade, permitirá que se penetre na essência da fotografia. As fotografias são nesta pesquisa a minha práxis, um ato de ação/reflexão.

Quanto às pesquisas educacionais com base em arte, algumas propostas foram relatadas inicialmente, entretanto devo esclarecer ainda que existem critérios definidos por Elliot Eisner para avaliar Arts-Based Educational Research. Estes critérios são: iluminating effect, generativity, incisiveness, generalizability, que podem ser entendidos como efeito de iluminação, generatividade, caráter de incisivo, generabilidade. Nesta tradução posso estar criando neologismos, porém ao expor o sentido que expressam estes critérios percebe-se como orientam 0 processo de leitura das fotos.

Barone e Eisner, em artigo em fase de publicação, escrevem que uma produção artística de Arts-Based Educational Research - ABER é elaborada para realçar significados, para estender, acrescentar e aprofundar conversações sobre a política e prática educacional. Estes autores consideram importante quatro conseqüências específicas desta produção de pesquisa que são os seus critérios de avaliação:

Illuminating effect - é a habilidade de revelar o que não tinha sido percebido ou observado, é distinguir o que é significativo de modo que a consciência sobre o campo educacional para o qual a pesquisa é dirigida seja aumentada. Neste sentido, uma produção artística como resultado de pesquisa culmina em um trabalho que é adequado referencialmente; isto é, segundo Eisner, torna o leitor apto a perceber o que o pesquisador através do seu trabalho reivindica. $\mathrm{Na}$ avaliação de uma produção desta natureza pode-se perguntar se o trabalho 
"emite luz sobre o fenômeno explorado". Ao observar as fotografias que apresento, venho perguntando: provocam reflexões sobre a escolha de imagens para a aula de arte? Qual é o foco? Nesta pesquisa, ao observar as fotografias, considero o critério illuminating effect correspondente a responder à pergunta: 0 que revela?

Generativity - é a habilidade de promover, é o caráter de gerar novas questões sobre o tema da pesquisa. Eisner afirma que uma das funções importantes deste tipo de resultado de pesquisa é levantar mais questões do que responder, este é um critério que se aproxima das produções artísticas contemporâneas. Quais perguntas, dificuldades e dúvidas as fotografias produzem em quem as vê? Assim, como categoria de análise, generativity equivale a perguntar sobre cada fotografia: o que produz?

Incisiveness - é a habilidade de "focar fortemente" nos objetivos e questões abordadas na pesquisa. Sobre este critério de avaliação Elliot Eisner pergunta: "A pesquisa indica o que é educacionalmente significante em uma escola, uma sala de aula ou na vida das pessoas da escola? O material alcança o coração do problema persuadindo o leitor da importância educacional dos eventos retratados?" Considero o critério incisiveness correspondente a responder à pergunta: o que aprofunda?

Generalizability - é a relevância do fenômeno fora do texto da pesquisa. Eisner pergunta se a pesquisa tem pernas, se é capaz de promover vinculações com outros temas. Este é um caráter que deverá tornar a produção artística fruto da pesquisa capaz de levar o leitor a fazer conexões que não tinham sido feitas antes. $\mathrm{Na}$ análise das fotografias, considero o critério generalizability o item que pergunta: o que amplia?

Quanto aos princípios dos autores Roland Barthes e Boris Kossoy, tomo-os nesta análise por tratarem de fotografias e por permitirem associar suas idéias aos 
critérios recém-expostos e às reflexões apresentadas ao longo deste trabalho. "Toda fotografia tem sua origem a partir do desejo de um indivíduo que se viu motivado a congelar em imagem um aspecto do real, em determinado lugar e época", afirma Kossoy (2001:36).

Há uma relação entre os elementos constitutivos da fotografia - assunto, fotógrafo, tecnologia - que levam ao congelamento da cena, à tomada da foto. No cotidiano contínuo, cria-se um tempo interrompido. No cotidiano escolar contínuo, toma-se a foto e se faz um testemunho e uma criação. O testemunho é a materialização em imagem da seleção de um recorte do que é visto, mediação e criação de quem vê e fotografa. Boris Kossoy (2001:50) defende que

o testemunho que é o registro fotográfico do dado exterior é obtido/elaborado segundo a mediação criativa do fotógrafo. É por isso que o testemunho e a criação são componentes de um binômio indivisível que caracteriza os conteúdos das imagens fotográficas. Qualquer que seja o assunto registrado na fotografia, esta também documentará a visão de mundo do fotógrafo.

Fundamentada em um processo dialético (Freire, 1987) percebo a escolha de uma abordagem para análise das imagens onde quem pesquisa está presente, não há isenção. Foi a presença diante do real e das imagens que contribuiu para trazer o pensamento de Roland Barthes: "Minha fenomenologia aceitava comprometer-se com uma força, o afeto; (...) eu só me interessava pela Fotografia por "sentimento"; eu queria aprofundá-la, não como uma questão (um tema), mas como uma ferida: vejo, sinto, portanto noto, olho e penso" (1984:38-39). Para aprofundá-las, tomei algumas fotos das quase 500 produzidas em um ano de pesquisa. Tratei-as como ferida no sentido de um corte, uma brecha para nelas entrar: vi, senti, notei, olhei, pensei. Assim, recorri a cores. Poderiam ser aqueles lápis de cores que secretamente compartilhavam meu refúgio atrás da poltrona amarela na casa da minha avó. Num programa de fotoshop fiz as fotos em pretoe-branco e colori alguns detalhes. Este processo de colorir proporcionou uma observação duradoura. 
As imagens do real obtidas nas escolas e nos encontros com as professoras fizeram com que uma realidade fosse aprisionada, as fotos pararam a realidade por um momento. Estes instantes decalcados do real e nesta tese apresentados como imagens/pesquisa fazem agora com que se reanimem as fotografias através da discussão sobre elas. Tomo o cuidado de não usar a fotografia como um instrumento para despersonalizar minha viva relação com o mundo. "Num mundo real, algo está acontecendo e ninguém sabe o que vai acontecer. No mundoimagem, aquilo aconteceu e sempre acontecerá daquela maneira (Sontag, 2004:183). Está claro que trato de imagens para abordar um cotidiano em movimento contínuo, um método de dar realce ao real.

Para a análise das fontes fotográficas associei aos critérios de avaliação de Arts-Based Educational Research a metodologia proposta por Kossoy e dois elementos propostos por Barthes. Kossoy propõe na metodologia de análise e interpretação das fontes fotográficas a desmontagem do signo fotográfico que tem como eixo a análise iconográfica e a interpretação iconológica, e assim se expressa:

A análise iconográfica tem o intuito de detalhar sistematicamente e inventariar o conteúdo da imagem em seus elementos icônicos formativos; o aspecto literal e descritivo prevalece, o assunto registrado é perfeitamente registrado no espaço e no tempo, além de corretamente identificado. (...) situa-se ao nível da descrição, e não da interpretação (...). A análise iconográfica, no caso da representação fotográfica, situa-se a meio caminho da busca do significado do conteúdo; ver, descrever e constatar não é o suficiente (Kossoy, 2001:95).

Kossoy recomenda para uma adequada análise aliar o estudo iconográfico à interpretação iconológica:

É este o momento de uma incursão em profundidade na cena representada, que só será possível se o fragmento visual for compreendido em sua interioridade. Para tanto, é necessária, a par de conhecimentos sólidos acerca do momento histórico retratado, uma reflexão centrada no conteúdo, porém num plano além daquele que é dado ver apenas pelo verismo iconográfico. É este o estágio mais profundo da investigação, cujos limites não são cristalinamente definidos. Não raro o pesquisador se surpreende refletindo 
neste plano pós-iconográfico, buscando os elos para a compreensão da vida que foi (Idem:96).

Os elementos propostos por Barthes (1984), em seu interesse particular por fotos, tratam de uma co-presença, nomeiam uma dualidade já citada na introdução: studium e punctum. Diz este autor que é pelo studium que ele se interessa por muitas fotografias. O studium é para ele o interesse humano, um afeto que determinadas fotografias despertam culturalmente. Sobre o studium lemos em Roland Barthes (1984:45-46):

O primeiro, visivelmente, é uma vastidão, ele tem a extensão de um campo, que percebo com bastante familiaridade em função de meu saber, de minha cultura; esse campo pode ser mais ou menos estilizado, mais ou menos bem sucedido, segundo a arte ou a oportunidade do fotógrafo, mas remete sempre a uma informação clássica (...) É pelo studium que me interesso por muitas fotografias (..) pois é culturalmente (essa conotação está presente no studium) que participo das figuras, das caras, dos gestos, dos cenários, das ações.

Continuando, encontramos um sentido para o segundo elemento proposto:

O segundo elemento vem quebrar (ou escandir) o studium. Dessa vez, não sou eu que vou buscá-lo (como invisto com minha consciência soberana o campo do studium ), é ele que parte da cena, como uma flecha, e vem me transpassar. Em latim existe uma palavra para designar essa ferida, essa picada, essa marca feita por um instrumento pontudo; essa palavra me serviria em especial na medida em que remete também à idéia de pontuação e em que as fotos que falo são, de fato, como que pontuadas, às vezes até mesmo mosqueadas, com esses pontos sensíveis; essas marcas, essas feridas são precisamente pontos. (...) O punctum de uma foto é esse acaso que, nela, me punge (mas também me mortifica, me fere) (Barthes, 1984:46).

As fotografias apresentadas foram escolhidas para representar a intenção de esclarecer, aclarar, iluminar imagens, sob orientação do princípio illustro imago, mas também pela associação da interpretação dos elementos punctun e studium, de Barthes, e dos critérios de avaliação de Arts-Based Educational Research, de Eisner. Estes fundamentos da análise deram origem à criação de critérios definidos durante a apreciação das fotos. Por uma repetição de elementos da foto ou variação de contexto, as fotografias foram divididas em: Isto é arte - as 
imagens apresentadas na sala de aula; Cotidiano - algumas representações do universo visual das professoras; Produções - fotografias das criações visuais produzidas pelas professoras. Em meu processo de conscientização diante das fotografias vivi binômios indivisíveis: ação/reflexão e testemunho/criação.

As fotografias foram produzidas em cores. Cada uma delas foi por mim observada e, posteriormente, o elemento que na cena da foto representa o objeto desta pesquisa foi mantido em cor e todo o restante da foto foi alterado para pretoe-branco. Esclareço que neste procedimento nem sempre o objeto em cor coincide com o elemento punctum.

As fotografias selecionadas estão organizadas nos três grupos anteriormente citados de acordo com o elemento que foi marcante no processo de apreciação. $O$ objetivo do acompanhamento de aulas de arte nas escolas e das visitas nas residências das professoras centrou-se em identificar as imagens ${ }^{33}$ utilizadas para os processos de ensino. O objetivo primordial que conduziu a pesquisa são as imagens selecionadas pelas professoras; segue deste aspecto um primeiro grupo de três fotografias. As professoras mostram imagens durante suas aulas e durante as entrevistas domiciliares. Neste conjunto o que marca e abre a reflexão é a imagem da própria professora mostrando uma imagem. Cada uma das fotografias foi por mim observada por longo tempo. A intenção da pesquisa focou meu olhar nas imagens usadas pelas professoras em aula, assim a ação inicial foi colorir e destacar as imagens do acervo didático. Este grupo de fotos evidenciou as imagens que são mostradas em sala de aula. Chamei a este grupo de Isto é arte.

Neste mesmo longo processo de apreciação das fotos criei outro grupo ao qual nomeei Cotidiano, no qual estão algumas fotografias que mostram imagens estéticas, padrões visuais presentes no contexto diário das professoras. Como

\footnotetext{
${ }^{33}$ Embora nos anteriores capítulos de fundamentação recorri aos conceitos de Maffesoli e Oliveira, entre outros autores, considero importante esclarecer que a acepção atribuída para a palavra imagem aborda as imagens artísticas, representação da arte, as imagens estéticas e outras manifestações visuais que se apresentem nas aulas de arte.
} 
decorrência deste conjunto surgiu o terceiro grupo de imagens para análise. São fotografias que permitem discutir o universo criativo e visual particular das professoras; foram tomadas em entrevistas, na observação da escola e na observação em aula. A este grupo de fotos nomeei Produções. Um orbe visual que vai à escola, gira em torno dela, mas não faz parte diretamente da aula de arte.

\subsubsection{Isto é arte}

Vou direto ao ponto que me atinge pela própria fotografia, o que me punge: a boca da professora, aberta, enuncia, fala com energia. No olhar sobre o todo da imagem a informação que se tem é que é uma sala de aula. Textos escritos no quadro e no cartaz atrás da professora. Vejo também, para minha surpresa, um "quadro de pregas" vazio. O "quadro de pregas" é uma tecnologia educacional criada por professores e utilizada nas décadas de 60 e 70, assim como o "álbum seriado", "flanelógrafo", e outros instrumentos para suporte de ilustrações, cartões e outros materiais didáticos.

A professora tem a mão direita levantada na altura da cabeça, em sua mão uma reprodução, do tamanho de uma carta de baralho, da obra Rosa e azul de Renoir. A reprodução foi feita pela professora, uma cópia, posteriormente colorida, recortada, colada sobre uma carta de baralho e plastificada. A imagem tem vários usos, é peça de jogo, é cartão para circular entre os alunos, é referência de Renoir para a professora.

Na minha intervenção para destacar o objeto da pesquisa, colori apenas o cartão com a reprodução; entretanto, no cenário da sala de aula, o que investe sobre mim é a professora que fala. O que a fotografia revela? Quais questões ela provoca? O olhar para a fotografia leva a uma vastidão de reflexões. É um grito, 
uma pregação? É a arte entrando na escola? A professora será uma guerreira que levanta um escudo, a reprodução? A mão que levanta e mostra a imagem será imposição que assusta, será santidade que emana saber?

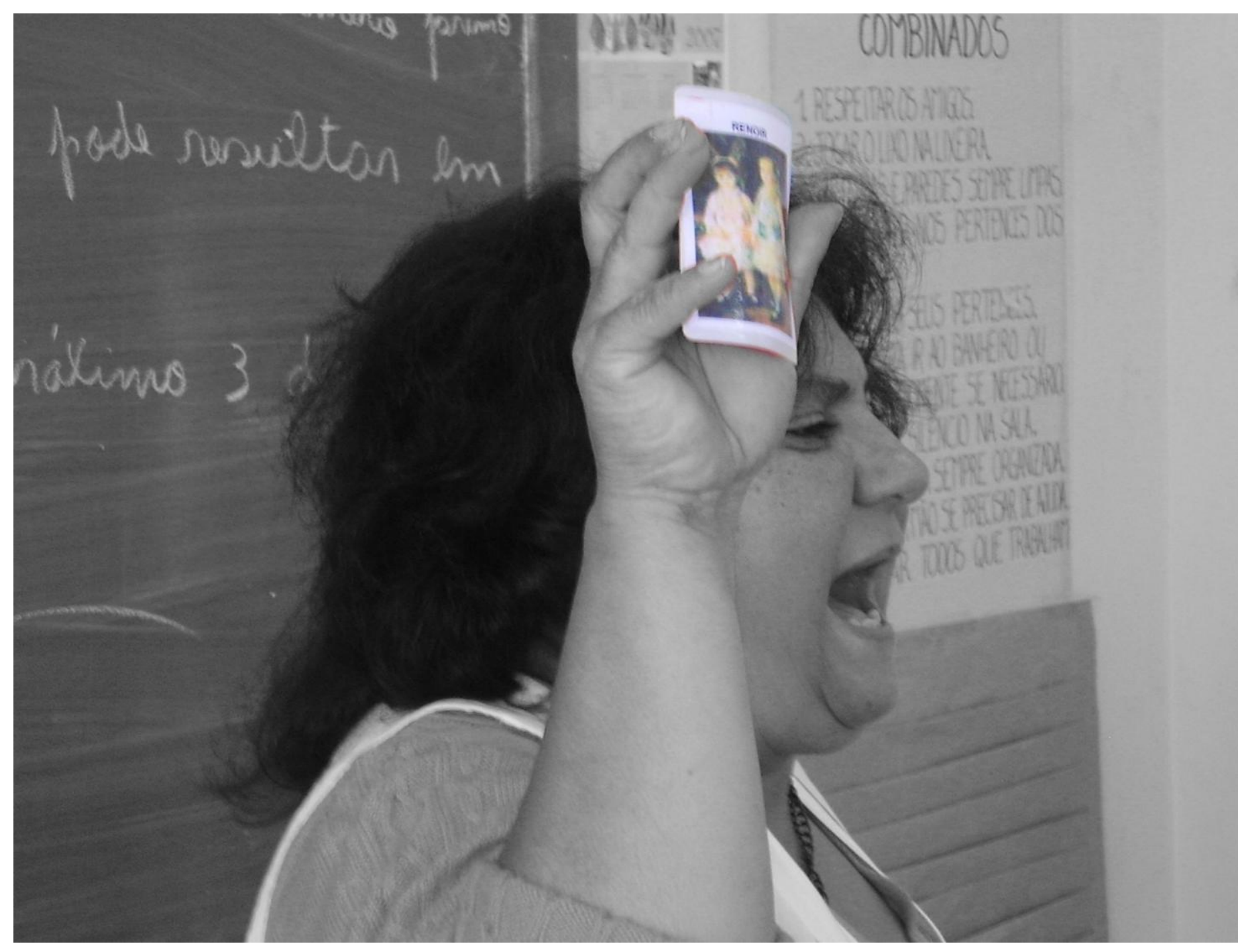


No âmbito da pesquisa sobre as imagens que as professoras usam na aula de arte, a foto dá visibilidade a uma revelação: o empenho da professora em criar materiais, em familiarizar seus alunos com artistas e suas obras. O que o jogo faz aqui é uma associação de nomes, identificação de artistas e imagens, reproduções de obras bem divulgadas em livros, revistas, catálogos e outros meios. O jogo está distante de uma experiência com a obra, até mesmo porque se trata de uma reprodução. Neste aspecto, esta fotografia como resultado da pesquisa lança nova questão: as reproduções estão distantes de provocar a experiência da própria arte; entretanto, provocam a experiência reflexiva que a arte gera?

Eliot Eisner, ao tratar de critérios para avaliar produções artísticas como resultado de pesquisa, como vimos anteriormente, pergunta se a produção, neste caso a fotografia, alcança o coração do problema. Considerando as perguntas elaboradas na pesquisa como o coração do problema, mesmo que tenham sido abordadas no item anterior, considero importante relembrá-las:

Quais imagens professores de arte selecionam para apresentar aos seus alunos? Serão imagens de obras clássicas? Modernistas? Contemporâneas? Serão reproduções de obras encontradas em catálogos de exposições? Revistas? Livros de arte? Serão reproduções da arte européia? Datadas de determinada época? Serão reproduções da arte de distintos grupos étnicos? Serão reproduções de obras de artistas locais? Artistas reconhecidos pelas instituições? Serão imagens produzidas pela cultura visual? Qual a variedade de imagens que encontramos nas aulas de arte? Como as professoras utilizam as imagens em aula?

As fotografias respondem a estas perguntas. Nesta fotografia vemos que a reprodução usada como elemento de jogo didático origina-se em uma obra clássica, européia, culturalmente reconhecida e instituída. A imagem mostra a reprodução de uma obra distante do contexto artístico local, mas pode ser aproximada a outros temas por abordagens sobre os aspectos culturais, tais como vestiário, costumes, gênero. 
$\mathrm{Na}$ minha presença no momento da foto, vivenciei a expectativa das crianças pela chegada da professora na sala de aula e sobre a atividade que seria realizada. Durante o jogo, a expectativa transferiu-se para cada carta de baralho que seria mostrada. Os alunos conversam entre si, perguntam qual é o artista. Vou marcar ponto? Qual será a obra? É importante destacar que muitos alunos referem-se às reproduções como o objeto de arte, como a própria arte. Este fato se apresentou repetidas vezes, embora as professoras destaquem sempre estar trabalhando com reproduções. A professora tira as cartas de baralho uma após a outra de dentro de uma caixinha por ela produzida. Surge uma variedade de nomes, tais como Salvador Dali, Frida Kalo, Modigliani, Michelangelo, para cada reprodução é dito o nome do artista que produziu a obra original, os alunos então procuram em uma cartela a cópia da imagem que é mostrada. A atividade é recreativa; porém, segundo a professora, contribui para a formação de um repertório de reconhecimento, identificação de artista e obra. Esta atividade, que aqui comento isoladamente, atende ao objetivo de recreação e ao objetivo de memorizar nomes de artistas e suas obras mais divulgadas, ação que introduz os alunos a uma superficial adaptação cultural. Assim como a professora se empenha em criar e diversificar os materiais e imagens para uso em aula, também tem sério empenho na aprendizagem dos alunos e na qualificação de suas ações. Nesta atividade, contudo, considero que não alcança o que se pretende na atualidade da arte/educação em termos de leitura e significação de conteúdos.

A fotografia da professora com uma carta de baralho que reproduz Renoir faz vinculações com outras discussões também pertinentes às questões educacionais. Embora a professora empenhe-se na ampliação da percepção crítica dos alunos, destacando no campo da visualidade os textos não-verbais, a fotografia nos remete ao predomínio da escrita que vigora na educação. No primeiro plano da foto temos a imagem na mão da professora, no segundo plano notamos que o quadro na sala de aula está escrito e que na parede há um cartaz com o texto dos "combinados" - são os termos de organização, convivência e 
respeito mútuo que cada turma elabora. O que quero enfatizar é que o pano de fundo para a professora e para a reprodução em sua mão pode ser mais forte e, mesmo que indiretamente, pode prevalecer sobre a imagem.

O desenho de Heidy de Assis Corrêa (1926-2001), artista que viveu em Florianópolis, é o foco da aula representada na próxima fotografia. A imagem apreciada em aula é uma reprodução publicada no livro Hassis na Praça XV de Novembro, no qual estão reproduzidos os painéis criados por este artista para o passeio da Praça XV e executados em petit pavê em 1965. O livro permite visualizar o conjunto deste trabalho que faz referência a temas da cultura local. Foi folheado pela professora, mostrando página por página aos alunos. Por alguns momentos ela circula entre as carteiras, enquanto conversa com os alunos, expõe informações sobre o artista. Responde a perguntas diversas sobre técnica, dimensões, sobre o tema dos desenhos e suas aproximações com o cotidiano dos alunos.

Quando invisto meu olhar sobre o campo da fotografia, o elemento studium de Barthes, esta mostra um ambiente de sala de aula, professora na frente dos alunos com a imagem em suas mãos. O quadro atrás da professora sugere novamente uma sala de aula convencional. Há texto verbal no quadro de giz.

O que a fotografia pode perguntar? Ou sugerir? O que revela sobre o objeto da pesquisa? Ao abordar a fotografia pautada pelas perguntas iniciais da pesquisa posso indicar algumas respostas. A imagem selecionada está em um livro publicado por órgão público municipal e distribuído em instituições culturais e de ensino. Considero que pode ser um conjunto de imagens acessíveis aos professores de arte, desde que o livro tenha possibilidade de circulação nas instituições. É conhecido, e esta pesquisa comprova isto, que qualquer divulgação sobre uma exposição, livro, catálogo, folder, cartaz, cartões, matérias em jornais e revistas transformam-se em material didático. Todas as professoras entrevistadas possuem suas coleções de imagens procedentes de livros, cartazes, catálogos, 
cartões-postais, revistas. Encontrei estas coleções guardadas em caixas e pastas, por sua vez guardadas em prateleiras, junto aos seus livros ou dentro e sobre armários. As reproduções em dimensões maiores encontrei atrás de um sofá e sob um colchão.

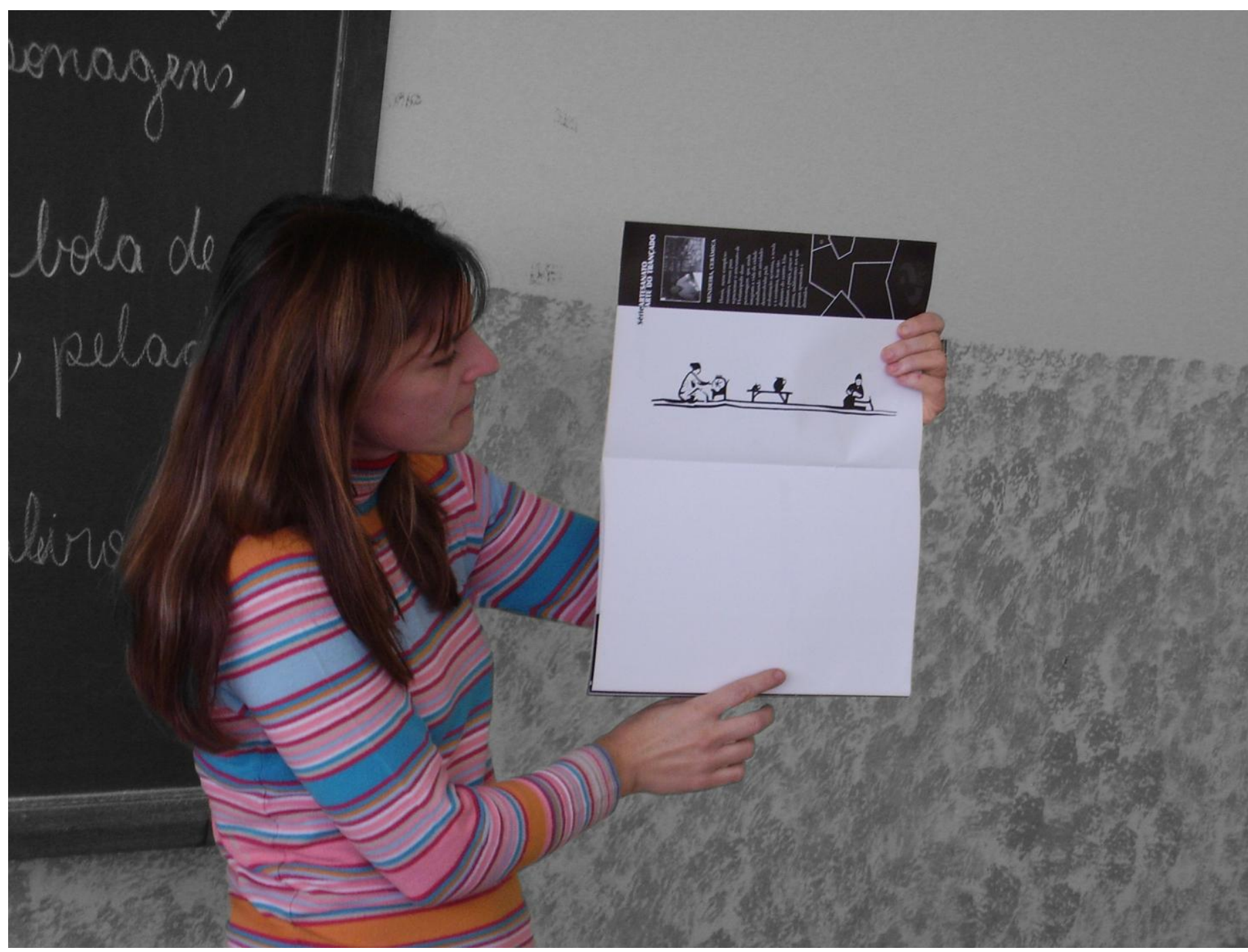


$\mathrm{Na}$ qualidade de material didático, as imagens que reproduzem arte são meios de aprendizagem e estudo para as professoras e seus alunos. São recursos para determinado assunto ou objeto de ensino, não são o próprio objeto de arte. São suportes para atividades de ensino e conhecimento em arte considerando sempre a distância entre cor, textura, tamanho real e reproduzido; considerando, também, a distância entre a reprodução e a experiência viva em relação com a arte. São representações e são consideradas como tal pelas professoras. Em uma das entrevistas domiciliares, a professora afirmou: Minhas melhores reproduções, as maiores ou aquelas de ação educativa de exposições, eu não levo para a escola... para não estragar com todos os alunos pegando. É para eu olhar... Entretanto, as imagens estão sempre nas mãos das professoras, coladas no quadro, penduradas em varais. Em raras situações as reproduções feitas por instituições culturais circulam nas mãos dos alunos, exceto nos casos em que trabalham com livros de biblioteca, imagens de revistas ou trazidas por eles próprios.

Assim como esta fotografia revela um tipo de imagem e sua maneira de utilização em aula, indica também o uso de reproduções de obras de artistas locais. Trata-se de um artista que experimentou diversas linguagens, desenvolveu trabalhos em desenho, pintura, gravura, painéis e vídeo. Hassis é um contemporâneo, no sentido de ter vivido os dias atuais, porém sua produção mais divulgada, e por isso conhecida, é a pintura com cores e formas acentuadamente modernistas.

A fotografia alcança o coração da pesquisa, segundo os critérios de avaliação de Eisner, isto é, revela um tipo de imagem e seu uso; mas também gera novas questões e faz vinculações com outros temas. Quando a fotografia investe sobre mim, o elemento punctum da foto salta rapidamente. Ao meu olhar, dirige-se a página em branco, o dedo que segura a folha nem precisa indicar. Há um contraste que produz novas indagações. 
A fotografia faz ficar o que logo depois pode desaparecer. A cena desta foto poderá não se repetirá mais. Quando olho esta fotografia também olho a professora destacando a blusa que veste. Esta blusa com listras e esta página em branco formam uma cena que poderá não se repetir mais. No instante desta foto, em sala de aula, estava com a atenção em registrar informações para a pesquisa. No momento de seleção das fotografias para discussão das questões da pesquisa meu olhar foi absorvido por um contraste. O colorido e linhas da confecção contrastam visivelmente com o catálogo sem cor, contrastam com a página branca. Tomo este acontecimento para discutir os vínculos que esta fotografia tem com elementos da cultura que as professoras levam para a sala de aula. Trata-se apenas de uma blusa colorida e uma página em branco, porém o contraste produzido no instante da fotografia faz ficar uma vinculação com temas da cultura visual.

A professora leva para a sala de aula mais do que um livro e imagens, leva sua própria imagem. Como citei anteriormente, "o professor se expõe visualmente, fazendo-se visto". O contraste percebido na foto leva a reflexões sobre o que realmente mostramos em aula referente à arte, concepções de mundo e valores. Será a presença da arte no ensino uma página em branco, uma impossibilidade de relatos determinados, uma página aberta para a imaginação? Será a presença dos professores de arte uma figura marcante, repleta de estímulos visuais, uma figura preenchida de conteúdos determinados? Novamente a imagem fotográfica como resultado de pesquisa revela, produz, aprofunda, amplia reflexões.

$\mathrm{Na}$ foto que segue, o olhar da professora dirige-se para os alunos, provavelmente aqueles que estão mais distantes, pois logo à sua frente vejo três pequenas cabeças, quase fora da foto. São crianças, ainda pequenas. A professora chama a atenção para o desenho em sua mão. Novamente temos um dedo que indica uma imagem. Imagem e professora à frente de um quadro de giz onde se lêem nomes de profissões e outras palavras. É constante a presença do 
texto verbal como fundo para o que é imagem. É recorrente também a maneira como as professoras ocupam o espaço físico da sala de aula. Professoras em pé, alunos sentados. Professoras à frente do quadro de giz voltadas para os alunos, estes por sua vez, enfileirados e de frente para o quadro. As maneiras como as professoras se movimentam, a entonação da voz, o modo como falam, sentam, gesticulam e ocupam o espaço da sala de aula é determinante e denotativo de suas posturas em educação e ensino de arte.

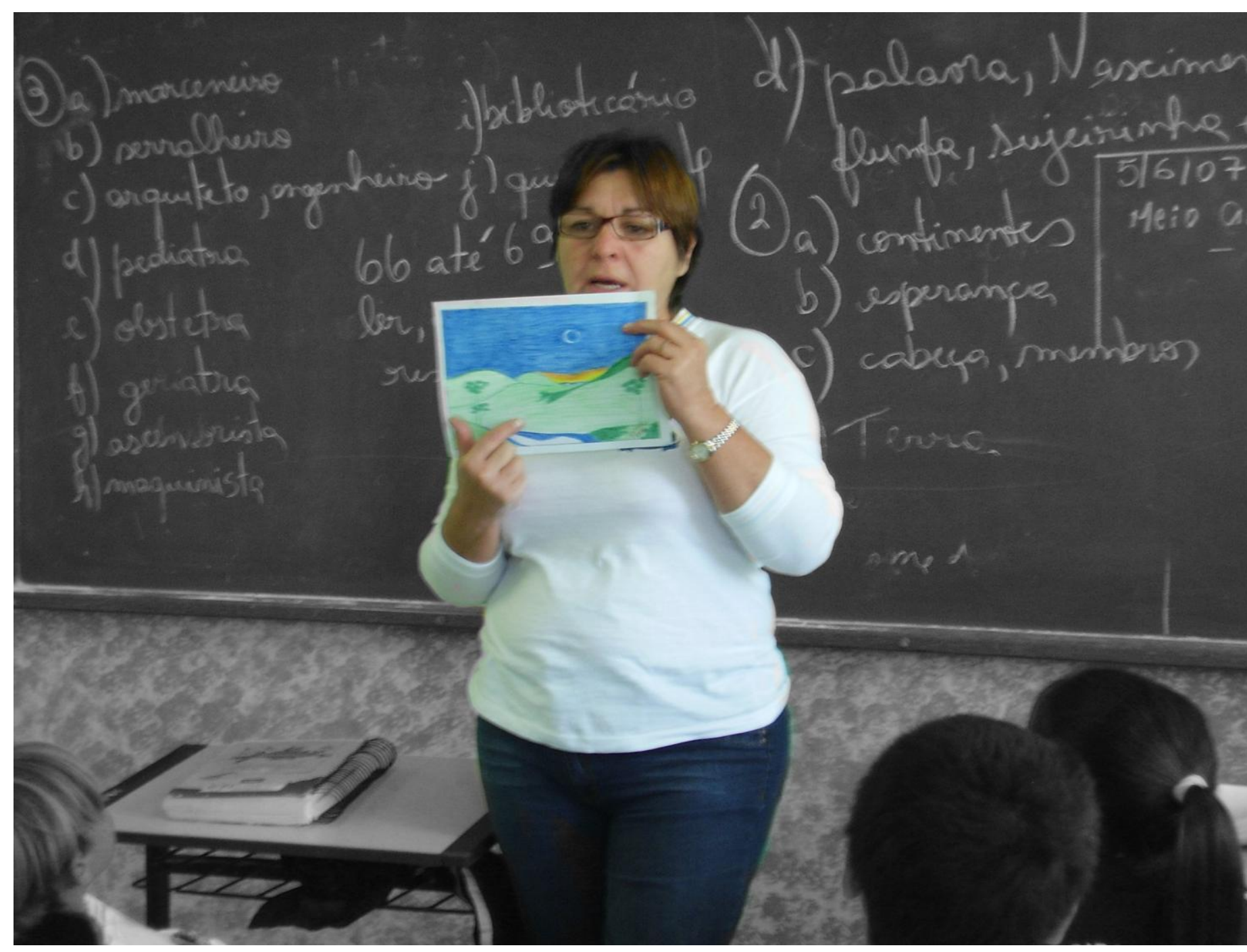


A professora mostra um desenho produzido por um dos seus alunos em outra turma. No instante da tomada da foto, a professora enfatiza a maneira como toda a superfície do papel, dentro das margens, foi preenchida com lápis de cor. Considerando os critérios de avaliação para as pesquisas educacionais com base em arte - Arts-Based Educational Research, de Elliot Eisner, esta fotografia revela que as produções dos alunos também são objeto de apreciação, sendo que nem sempre predominam as reproduções de obras de arte entre as imagens que são dadas a ver.

Como resultado de pesquisa, a foto pode responder à pergunta sobre como as professoras utilizam as imagens em aula. Neste caso o desenho que é apresentado ao olhar das crianças é usado como referência para as novas produções, e também é mostrado como orientação para atender aos critérios de avaliação da professora para a atividade proposta - desenho com tema. Num pequeno espaço do quadro de giz, delimitado por dois traços, lê-se a data 5/6/07 e o título Meio Ambiente, escritos no início da aula de arte. Temas, datas comemorativas, ainda predominam sobre conteúdos específicos da arte? Há uma amplitude de assuntos e abordagens que o contexto atual da arte cria para as atividades de ensino. Entretanto, ilustrar temas como atividade expressiva desvinculada do âmbito dos saberes e experiências em arte pode não ser considerado como processo ensino-aprendizagem.

Continuando a investir no campo studium, nesta foto a professora usa uma blusa branca que faz fundo para o desenho em cor. Isto valoriza a visualização da imagem. Inverte-se a situação da foto antecedente, porém desta vez o realce que o desenho ganha perturba tanto quanto o contraste anterior. Será a possibilidade de produzir estereótipos sobre o desenho, a técnica em colorir, a possível discriminação de trabalhos de alunos? 
A fotografia amplia a discussão para além das imagens que são apresentadas em uma aula de arte, atendendo ao critério - generalizability - de promover novas questões. Orienta para reflexões sobre a formação docente inicial e sua continuidade na vida profissional. Quantas vezes a aula de arte ainda é concentrada em desenhar em papel tamanho ofício? Para desenhar serão sempre necessários canetas, giz de cera e lápis de cor?

Das palavras escritas na aula anterior e deixadas no quadro, sobre o ombro esquerdo da professora lê-se: esperança. Esta é a imagem/palavra que salta da foto e investe sobre mim. Esperança é uma das emoções fundamentais, é expectativa da realização de sonhos, é confiança em conseguir o que se deseja. $O$ que a professora deseja e sonha? Qual a esperança que as crianças vislumbram sobre os ombros da professora?

\subsubsection{Cotidiano}

O contexto diário das professoras está repleto de marcas pessoais, histórias, afetos, objetos. Minha intenção foi realizada: entrevistar, observar e fotografar o ambiente familiar. Busquei no cotidiano das professoras indícios de familiaridade com arte e outras imagens. As fotografias apresentam algumas das escolhas estéticas das professoras.

Nas paredes do ambiente da foto que segue destaca-se um único quadro, centralizado sobre a escrivaninha onde a professora habitualmente prepara aulas, lê, escreve, utiliza o computador. A reprodução da pintura Retrato de Dora Maar, de Picasso, se apresenta sobre vários objetos dispostos na bancada. A reprodução foi mantida em cor, pois conforme os objetivos da pesquisa é a 
imagem de arte que foi encontrada exposta na casa da professora. Na intervenção sobre a fotografia também mantive a cor original das caixas sobre o armário. A cor nesta fotografia indica um referencial em arte para a professora e o seu arquivo de materiais didáticos. Este é o cenário da foto em seu elemento studium.

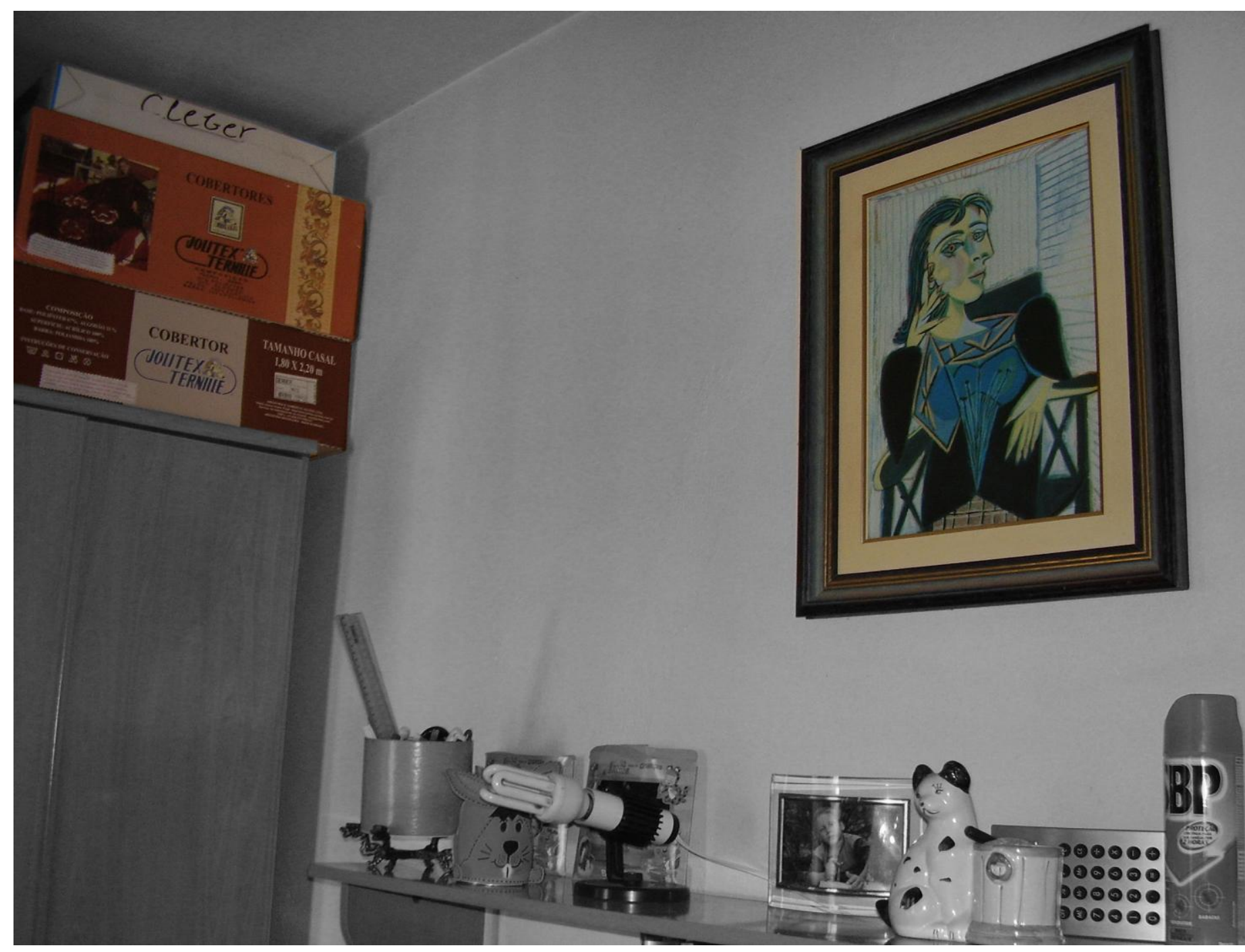


O elemento punctum encontro no conjunto de objetos sem cor. Entretanto, antes de enunciá-lo percebo a senhora soberba em sua moldura sobre os portaslápis, o coelho estereotipado, a lâmpada, o porta-retrato, o gato de porcelana, uma caixa de som e a lata de inseticida. A fotografia gera questões, faz vinculações com temas sobre arte e cotidiano e revela a presença do artista conhecido através de uma de suas obras. Dora Maar está acima dos objetos, mas não é ela quem investe sobre mim, ela contribui com a mão que indica e com o azul do vestido que aponta como uma seta. Sua postura altiva contrasta com a singeleza do gato. É o gato que salta entre os objetos utilitários simbolizando afeto. A fotografia no porta-retrato ao lado do gato poderia ser um elemento punctum, há ali alguém que nos olha. Porém, a luz que reflete é uma interferência que provoca distanciamento.

O gato, como elemento punctum, e a reprodução, como imagem de arte, estimulam respostas às perguntas-categorias de análise da fotografia: $O$ que revela? O que produz? O que aprofunda? O que amplia? A fotografia revela a presença de diferentes objetos estéticos no universo da professora. Aparentemente a fotografia pode indicar a preponderância de valorização de um objeto sobre o outro. A professora reconhece qualidades estéticas distintas, a reprodução como objeto artístico e o gato como objeto decorativo, porém ambos são motivo de satisfação pessoal ao serem admirados. Entretanto, uma cópia da reprodução está entre as imagens, guardadas nas caixas, para serem levadas às escolas. Quanto ao gato, não circula além das dimensões da prateleira.

As perguntas sobre a fotografia fazem com que se apresente uma possibilidade de aproximação do gato com a contemporaneidade da arte. Tratei nas fundamentações desta pesquisa, como princípio da pós-modernidade, da diluição de limites entre erudito e popular, marginalizado e institucionalizado. As reproduções de obras institucionalizadas são dominantes nos acervos das professoras, por isso mesmo são as mais freqüentes nos projetos de ensino. As 
professoras deste campo de pesquisa escolhem, apresentam e denominam como arte as reproduções do que já está institucionalizado como arte. Será que, entre as imagens que as professoras possuem uma fotografia do objeto gato criaria a possibilidade de aproximação entre a arte contemporânea e o ensino de arte?

$\mathrm{Na}$ foto que segue, são pessoas das relações familiares e de amizade que se encontram em fotografias nos quadros expostos na entrada da casa da professora. Há somente um desenho de criança exposto. Estas são as imagens que habitam o lugar.

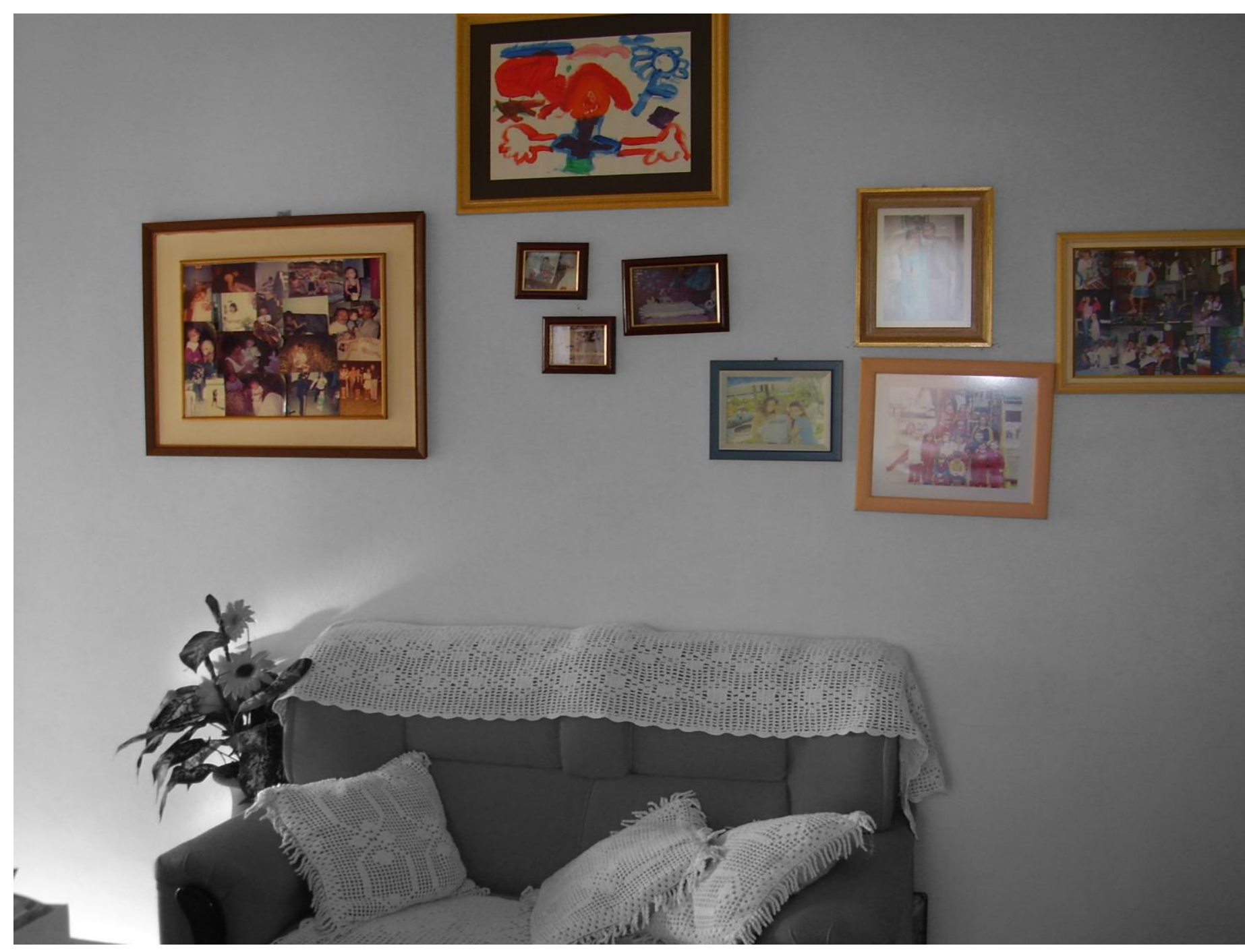


Somos fisgados por uma sensação de movimento causada pela distribuição dos quadros na parede. Um possível desalinho, uma agitação de molduras ou pessoas fotografadas. Talvez uma agitação das muitas histórias ali representadas. São as histórias latentes nas quais não consigo penetrar que me causam desconforto? Há uma história que eu possa recuperar nesta fotografia?

No âmbito da pesquisa científica poderia afirmar que há informações insuficientes na fotografia como substância da pesquisa. Porém, como resultado de uma pesquisa baseada numa proposta artística recorro às perguntas elaboradas a partir dos critérios de avaliação enunciados por Eisner. Ao observar a fotografia pergunto: $O$ que revela? $\mathrm{O}$ que produz? $\mathrm{O}$ que aprofunda? $\mathrm{O}$ que amplia? Muitas são as respostas conforme diferentes olhares e diferentes saberes. Este é o estímulo ou agitação que esta fotografia provoca, percebo que não há necessidade de um relato que responda a todas as perguntas. $\mathrm{O}$ instigante - e deste modo esta fotografia satisfaz aos objetivos da pesquisa - é a possibilidade de muitas respostas e histórias.

A reorganização dos quadros na parede poderá fazer com que as histórias sejam reinventadas, contadas de outras maneiras. As lacunas poderão ser outras. O movimento gerado pela fotografia sugere pensar sobre a diversidade de articulações com imagens que se pode projetar para as aulas de arte.

Entre o movimento que a fotografia causa, encontro um lugar de tranqüilidade. Sobre o sofá estão as almofadas e a manta de crochê. Porém, ao lado, no ângulo de maior incidência de luz da fotografia, está um arranjo de flores artificiais. $O$ conforto do crochê é tomado pelo salto do que me fere. O punctum vem das flores mortas. $O$ contraste na fotografia se faz entre o movimento dos quadros na parede e a estagnação das flores. O que a fotografia pode perguntar? Estagnação? Movimento? O ensino de arte na contemporaneidade vive uma agitação desorganizada? Vive um movimento em busca de equilíbrio? 
Ainda tratando do cotidiano, segue outra fotografia que nos apresenta uma diversificação de cores e formas. São dois modelos em dois objetos distintos. Percebe-se um padrão organizado, quadrados e cores, e outro possivelmente aleatório, listras. Sobre a vastidão do cenário da fotografia, somos absorvidos pelas formas e cores. Quanto ao elemento punctum da foto acredito que se encontra na linha diagonal e ondulada, formada no encontro entre a manta e o tapete. Fica evidente que a professora se interessa por uma estética que não é do mundo da arte institucionalizada. O que vemos são padrões estéticos não instituídos no mundo da arte.

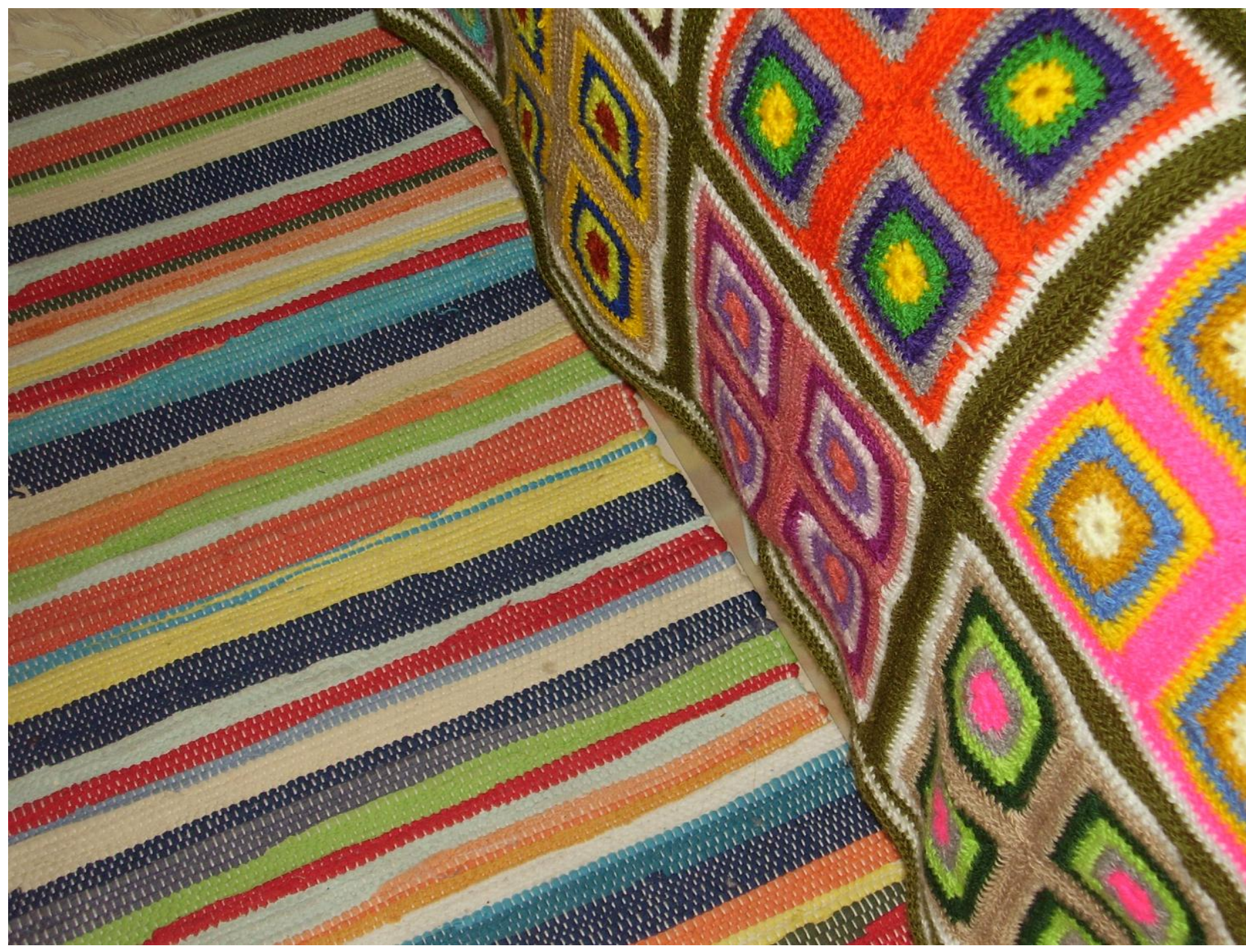


Novamente recorro às perguntas elaboradas a partir dos critérios de avaliação enunciados por Eisner. Ao observar a fotografia como resultado de pesquisa, pergunto: O que revela? O que produz? O que aprofunda? O que amplia? Ensaio dizer que a familiaridade cotidiana das professoras está muito mais em contato com as imagens produzidas no âmbito familiar, e imagens das ruas, das revistas, da produção artesanal loca,I do que em contato com imagens de museus e instituições culturais. Entre as tramas e urdiduras, entre os quadros elaborados um a um e costurados, a fotografia remete à formação do professor, que é contínua e permanente, ponto por ponto, linha por linha, quadro por quadro.

\subsubsection{Produções}

Os objetos são concretos. Mesa da professora, cadeira, pasta, papéis, toalha, estojo de lápis e canetas, garrafa e pote plásticos, rolo de fita adesiva, caixa de giz e apagador. Há na fotografia uma organização visual em diagonal da esquerda para a direita que culmina num abstrato facho de luz. Entre as nuances de cinza, do branco ao preto, destacam-se a forma triangular da luz, totalmente branca, e a caixa de giz, colorida.

Esta fotografia como substância da pesquisa indica valorizar a produção da professora em personalizar a sua caixinha de giz e apagador. A valorização da produção da professora está na aproximação entre o que ela faz e o que ela ensina. As criações produzidas pelas professoras poderiam ser motivadoras em suas aulas de arte, repercutindo em transformação e atualização dos projetos de ensino, valorizando a produção artística local em diálogo com os saberes da arte. 
O elemento punctum, que salta da foto em minha direção, é a caixinha colorida. O que revela? A necessidade de criação da professora. O que produz? Questionamentos sobre as relações entre os conteúdos e imagens trabalhadas em aulas e a produção criadora da professora. O que aprofunda? O que amplia? A professora terá outras produções? Alguma vez foram apreciadas e discutidas pelos alunos?

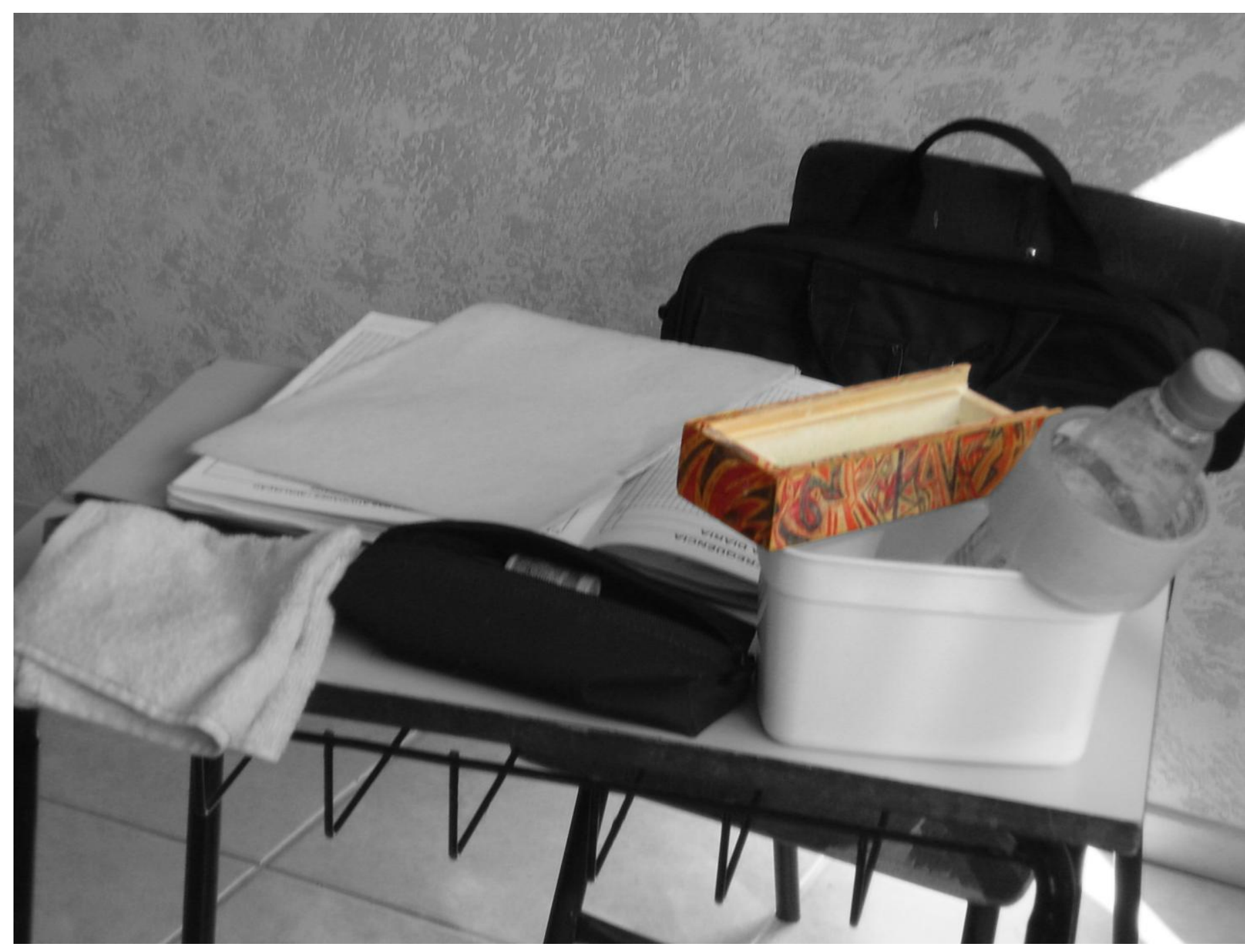


A caixinha de giz colorida é uma produção estética elaborada pela professora que precisaria estar incluída em seus projetos de ensino. Quais serão as competências, os conhecimentos necessários aos professores de arte para que expressões desta natureza sejam consideradas e conscientemente trabalhadas no processo de ensino/aprendizagem em arte? Ou ainda, quais serão as competências, os conhecimentos necessários aos professores de arte para que expressões desta natureza sejam motivadoras de processos de conscientização sobre arte nas perspectivas da pós-modernidade?

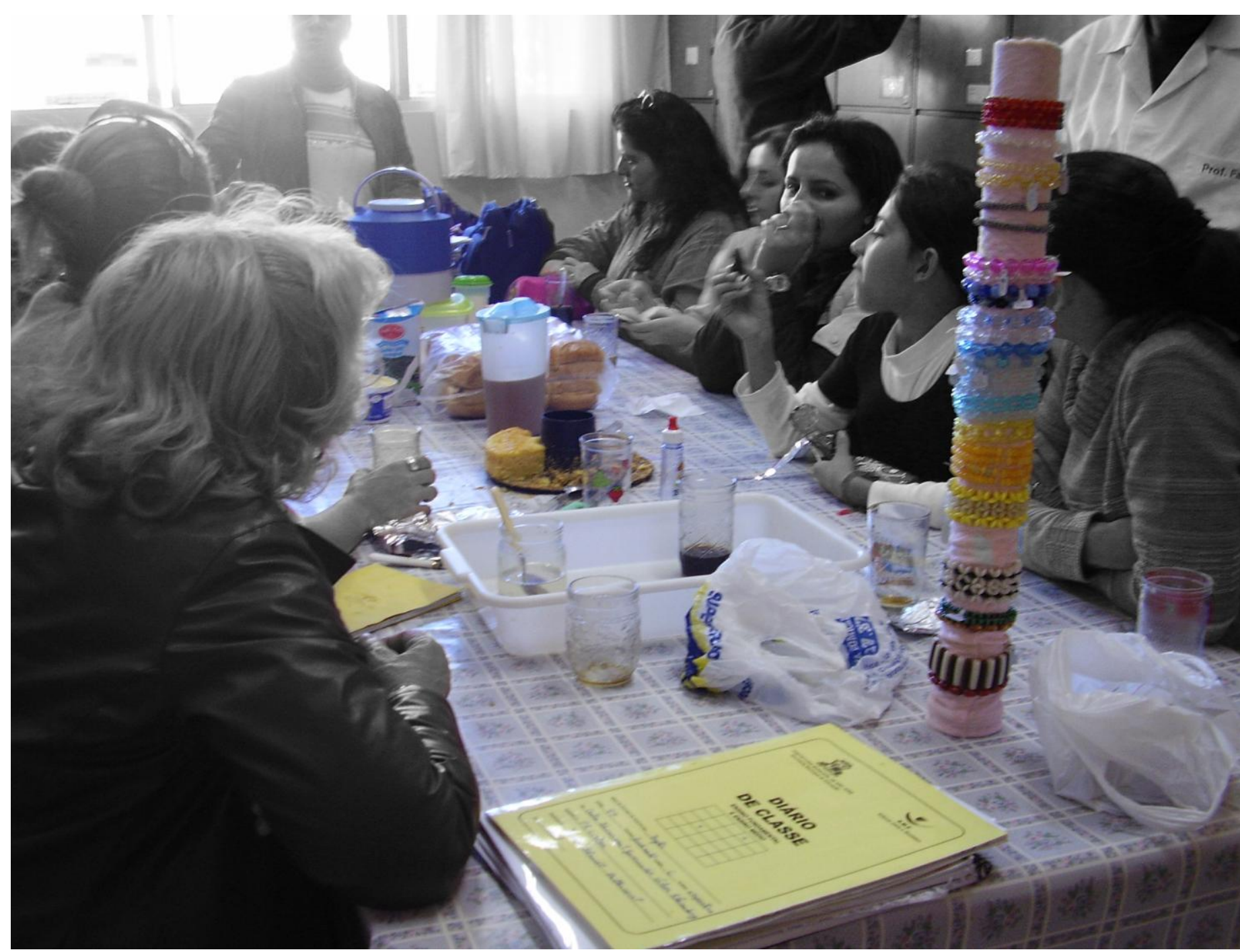


Outra mesa, desta vez em horário de lanche das professoras na escola. $\mathrm{Na}$ fotografia que apresento encontro outras produções das professoras deste campo de pesquisa. $O$ instante é de intervalo, as professoras tomam água, suco e café. Sobre a mesa há uma mistura de embalagens plásticas contendo bolo, biscoitos e pães. Sobre a mesa também estão um tubo com pulseiras e um diário de classe $O$ grupo conversa. Este é o cenário geral da fotografia.

Desta vez o que se destaca como produção da professora são as pulseiras organizadas no tubo revestido com tecido. $O$ interesse da professora em dividir, apresentar, comercializar sua produção com outras professoras é explícito.

O que parte diretamente da fotografia sobre mim, na qualidade de punctun, é o olhar da professora sentada ao lado direito, no centro. A mão sobre a boca, mas os olhos interrogam. O que diz a professora? A câmera fotográfica me autoriza a entrar. Entro na sala, mas não entro no grupo. Há uma preocupação geral em relação à minha percepção sobre as pulseiras e os conteúdos de arte. O que esta foto revela, produz, aprofunda, amplia? Serão as pulseiras abordadas nas aulas de arte, não como atividade mecânica, mas como tema para ampliar discussões e espaços para as produções excluídas ou para as produções artísticas contemporâneas?

O instante que a fotografia que segue revela é outro momento de lanche. Desta vez, servido durante uma tarde de entrevista e apreciação de materiais didáticos criados pela professora. Junto aos seus livros e materiais de aula a professora guarda e mantém em constante atualização um caderno por ela produzido. Poderia ser um livro de artista? São fotos, fitas, colagens, desenhos. A professora tem orgulho de seu caderno e o dedica à sua filha.

Servido junto ao café e ao chá está o pão-de-ló, está também o pão-por-Deus. É uma parte do caderno. Agradam à professora os recortes, os versos escritos, a variedade de cartões que podem ser criados. Agrada-me encontrar esta produção, 
descobrir em família que minha avó-materna, em sua arte das mulheres, elaborava em papel dobraduras, recortes, enfeites, para depositar seus versos e caligrafia. Constantemente era solicitada a criar pão-por-Deus para que vizinhos, familiares e amigos os endereçassem aos seus destinatários, este fato foi durante longo tempo fonte de renda para contribuir no orçamento familiar.

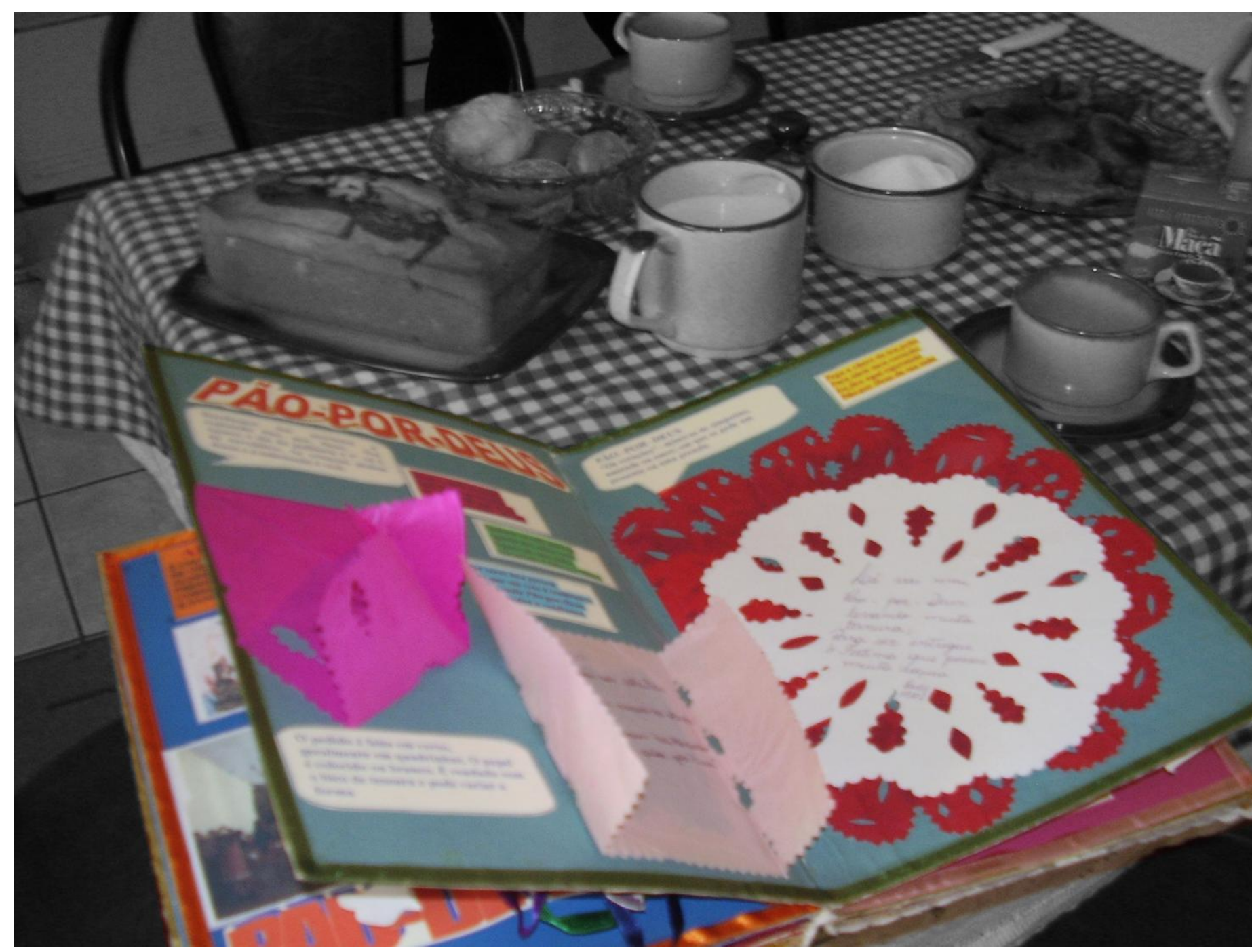


O pão-por-Deus é uma tradição da colonização açoriana na região de Florianópolis e São José. Veio para o Brasil no período de 1748 a 1756, via mar, com os habitantes das llhas dos Açores e da Madeira que aqui chegaram. São bilhetinhos que podiam ser enviados por homens ou mulheres, geralmente produzidos por mulheres. Versinhos transcritos em corações de papel recortados com delicadeza, produzindo o efeito de rendas em papel. São desenhados, coloridos, enfeitados, bordados. Transmitem pedidos de amizade, namoro, presentes e visitas. Manifestam "paixões escondidas, corações partidos, zombeteiros, irônicos, brincalhões" (Mannrich, 2007:12). Era uma forma de discretamente revelar amor a alguém.

Originou-se da necessidade das pessoas compartilharem entre si o pão como alimento e como sustento espiritual para suas histórias íntimas e sociais. Segundo Mannrich (Idem, p.20), em informações coletadas no filme Lendas, contos e outras histórias catarinenses, a expressão pão-por-Deus teve origem numa das ilhas dos Açores. Uma família abastada assando grande quantidade de pães foi chamada por alguns meninos que sentiram o cheiro do pão e mendigaram: pão-por-Deus!

O Pão-por-Deus como expressão de auxílio nasceu nos Açores. A solicitação na maioria das vezes era oral; por isso se diz que foi trazida como expressão. Depois passou a ser feita através de cantorias no mesmo Arquipélago. Mas a arte poética em si pode-se dizer que nasceu aqui no Brasil entre os açorianos e seus descendentes (...) pode-se dizer que os poemas serviram também como alento para a opressão sofrida pelas meninas açorianas no Brasil (Idem, idem).

A intenção de comunicação há muito tempo foi superada por outras tecnologias, entretanto ainda há quem faça o pão-por-Deus como recordação de uma prática popular na região. Lembro as palavras da artista americana Harmony Hammond sobre sua obra: "contactar toda uma tradição de sentimentos femininos e eliminar as distâncias entre pintura e escultura, entre a arte e a 'arte das mulheres', bem como entre a arte presente no artesanato e o artesanato presente na arte" (Archer, 2001:97). A fotografia, exposta anteriormente, fonte de pesquisa 
sobre o ensino de arte, produz em mim o efeito de acolher as produções visuais das professoras como forma de significação, atualização, conhecimento em arte.

A mesa está posta, o lanche servido. Qual alimento, qual "pão" me nutre? Será o caderno um alimento para a professora? O caderno poderá ser uma possibilidade de dissolução das fronteiras no ensino de arte entre erudito e popular? Será o caderno ou o Pão-por-Deus uma aproximação para a inclusão e compreensão da arte contemporânea no ensino de arte? A fotografia produz interesse sobre uma produção esquecida.

Algumas palavras se perdem Pelo vento, sem carinho. Espero que com o Pão-por-Deus Encontre novo caminho. 


\section{AFINAL, QUAL IMAGEM FICA?}

A imagem inicial apresentada nesta pesquisa foi a primeira fotografia que produzi, foi a primeira imagem que quis "iluminar", tirei-a de caixas e gavetas. Depois enfoquei a fotografia da sala de aula de ensino fundamental da "Escola de Primeiro Grau Graças a Deus". Por fim, apresentei as professoras de arte e suas imagens. Nesta trajetória, mais que introduzir um universo de pesquisa, vejo que mostrei alguns pontos do meu percurso de professora. Minhas primeiras alunas foram aquelas bonecas da primeira fotografia. Imagino que já ensaiava atitudes, discutia assuntos que para mim eram significativos e usava minhas referências de conversas em família, histórias que ouvia, contos, revistas, brincadeiras, ações cotidianas, descobertas, frustrações, acontecimentos e pessoas. O brincar de professora me fez começar com conteúdos muito próximos de um universo pessoal e local.

Da brincadeira de criança à vida profissional fui buscando novos conhecimentos e ampliei este universo. Por mais que idéias novas, reflexões filosóficas, competências acadêmicas, saberes diversos, muitas pessoas e histórias tenham participado e contribuído nesta expansão, o foco da minha atuação tem sido as relações de ensino que se realizam na escola, as relações entre professores e alunos no âmbito dos saberes da arte. É para a escola com seus integrantes que esta pesquisa se dirige. Foi em uma das entrevistas nas escolas que surgiu a pergunta: Qual imagem fica? Qual imagem fica desta pesquisa?

Neste processo de pesquisa, entre tantas perguntas e fotografias, outra imagem se apresenta. Tomo-a para encaminhar algumas constatações. É uma fotografia de um espaço em uma das escolas do campo de pesquisa, 


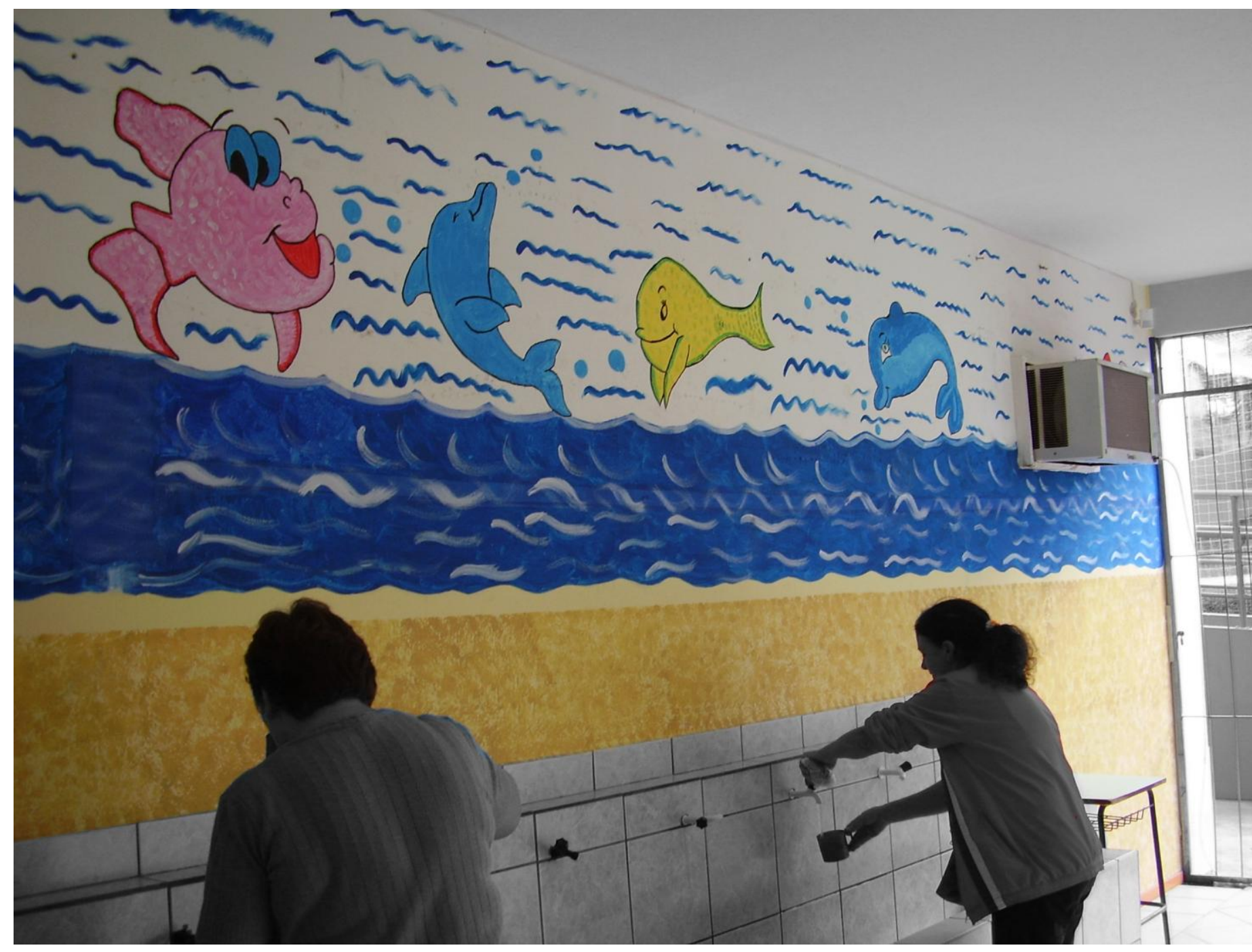

São muitas as imagens que se apresentam no cotidiano escolar em painéis, paredes, muros, quadros de avisos, cartazes. Esta fotografia mostra um detalhe de um pátio coberto e fechado com grades. Ali está construído um lavatório usado por alunos, professores e demais pessoas que participam da vida na escola, para beber água, lavar as mãos e outros utensílios. Sobre o lavatório uma pintura realizada para reforçar a idéia de lugar de água. As professoras de arte da escola (são duas para os turnos matutino, vespertino e noturno) fazem questão de 
esclarecer que a pintura não é produção delas. As crianças perguntadas sobre a pintura na parede usam expressões como: "É desenho pra criancinha de maternal", "É tosco, ridículo". Alguns afirmam que "é bonitinho". Considerando que em média os alunos têm 80 horas-aula de arte em um ano letivo, esta imagem reforça em mim a pergunta: qual imagem fica? Será a imagem vista diariamente, mesmo que sem muita atenção? Serão as imagens apresentadas nas aulas de arte, apreciadas por alguns instantes?

Assim como são incontáveis as imagens que nos cercam, são também muitas as perguntas sugeridas nesta pesquisa. Lembro então da afirmação de Ronaldo Entler: "Sem uma resposta que possa apaziguar definitivamente a pergunta, mais instigante é manter presente a interrogação" (2008:47). Não pretendo resposta apaziguadora, nem definitiva. Não nego também que me agradam algumas incertezas. Todavia, uma pesquisa acadêmica, mesmo que qualitativa, deve indicar retorno, possibilidades, propostas.

Este estudo dirigiu seu foco para professoras de arte e seus universos de imagens, mais especificamente, para as imagens que as professoras de artes visuais incluem em seus projetos de ensino. Quais são as possíveis respostas? Lembro que apenas dez por cento - quatro entre 40 dos professores de arte - da rede de ensino campo da pesquisa participaram integralmente. Isto indica que as constatações, possíveis respostas, não permitem generalizações, tratam de uma pequena amostra.

Sobre as imagens que as professoras mostram para seus alunos nas aulas de arte, predominam as reproduções de obras instituídas pela história da arte brasileira e universal. Nos questionários, sete entre 14 professores, isto é, 50\%, responderam que selecionam as imagens, reproduções da arte, a partir da história da arte. Nas entrevistas e grupo focal predominaram também as respostas que destacam a seleção de imagens por uma linearidade histórica. 
O outro grupo dos professores informou que seleciona as imagens conforme 0 acesso que tem a elas, isto é, a imagem é utilizada se está disponível e se é de simples aquisição. E ainda, usam as imagens que podem facilmente ser relacionadas ao cotidiano dos alunos. Apenas três dos professores que responderam ao questionário escolhem as reproduções de arte de acordo com os conteúdos determinados em seus projetos. Neste caso os conteúdos não se referem à história da arte, mas aos temas, artistas, elementos da linguagem visual e modalidades artísticas.

A variedade de imagens que encontrei nas aulas de arte corresponde aos nomes de artistas usados pelos professores como pseudônimos para se identificarem nos questionários. Uma professora identificou-se com o pseudônimo Cecília Meireles. Nos quatorze questionários respondidos, no estágio inicial da pesquisa, os nomes utilizados foram: Vincent van Gogh, citado por três professores; Gustav Klimt, Frida Khalo e Tarsila do Amaral foram citados duas vezes; Kandinsky, Jean Michel Basquiat, Susan Turcot e Amélia Toledo foram citados uma vez. É importante esclarecer que os nomes de Amélia Toledo e Susan Turcot foram usados como pseudônimo pelo motivo de que estas artistas têm uma produção que agrada e interessa às professoras que as mencionaram e que haviam sido vistas recentemente, porém só a obra de Amélia Toledo foi abordada em aula na escola.

As imagens são reproduções de obras clássicas e modernistas, européias e brasileiras, divulgadas predominantemente em reproduções publicadas em livros de arte e história. Apenas uma professora foi identificada utilizando catálogos de exposições. Os artistas apresentados são todos aqueles que de alguma maneira têm suas obras divulgadas por mídias, principalmente televisão e jornais. Neste aspecto, outra professora afirmou que mantém um arquivo de matérias sobre as Bienais de Artes Plásticas de São Paulo, o que leva a considerar que a arte contemporânea poderia estar presente em seus projetos de ensino. Porém este fato não foi confirmado na observação das aulas. 
Entretanto, nem toda imagem é explorada em seus conteúdos, relacionada com os saberes da arte, da produção, do contexto. Destaco aqui, como citado anteriormente, a insatisfação da professora que percebeu tratar a contemporaneidade de Carlos Asp segundo princípios formais modernistas, e a declaração da professora, no grupo focal, que afirmava distribuir as reproduções de obras e solicitava para os alunos falarem sobre o que estavam vendo sempre num nível subjetivo sem ampliação do repertório visual ou artístico do aluno.

Nas entrevistas nas escolas e nas residências, identifiquei que imagens de obras da contemporaneidade raramente estão incluídas pelas professoras de artes visuais em seus projetos de ensino, mas percebi vínculos que poderiam ser estabelecidos com as produções das professoras. Para isto seriam necessários professores com experiências e conhecimento em arte, capazes de ler, produzir e escolher conscientemente as imagens. Duas professoras assumiram claramente não ter conhecimento suficiente, demonstram insegurança e por isso negam-se a experimentar a arte contemporânea em suas aulas - penso que até mesmo em sua vida. Em outros depoimentos registrei que as professoras percebem dificuldades de aceitação e compreensão por parte dos alunos.

Considero que a aceitação e compreensão a que as professoras se referem devem partir das suas próprias atitudes, alcançando, assim, os alunos. É necessário manter-se capaz de atualização, discriminação, análise, escolha, crítica. Relembro algumas das perguntas, apresentadas anteriormente, com as quais sou abordada nos campos de estágio: O que é o contemporâneo? O que é modernismo e pós-modernismo? Quando é arte? É arte ou não é? Que aula posso criar a partir desta obra? Qual conteúdo encontro aqui? É necessária aos professores de artes visuais uma competência e abertura para leituras de mundo. A pesquisa bibliográfica, o fundamento teórico desta pesquisa é conteúdo imprescindível aos professores para desenvolver aceitação e compreensão de 
representações características que são próprias do que chamamos pósmodernidade.

As respostas são muitas e não uma só, ou o instigante é manter presente a interrogação. Há perturbação. Há conhecimentos diversos. Há imagens múltiplas. Ao professor de arte realmente caberia manter a confiança em suas escolhas advindas das informações e conhecimento que possuem eles próprios como sujeito. No ensino de arte e na formação de professores de arte as inquietações e questionamentos que fazem parte do contexto da arte são as atividades que lhes restituem a capacidade de análise crítica em relação a tudo o que vêem, não só ao repertório em artes visuais. Quando desenvolvemos um repertório, assim como em relação ao que vemos, temos que manter a idéia de que ele nunca está completo, haverá sempre algo a mais para ver. Há a necessidade de atualização constante.

Nesta pesquisa recorri a alguns instrumentos que contribuíram para constatações objetivas sobre o uso de imagens nas aulas de arte. Também recorri às imagens fotográficas, que por vezes permitiram transitar pelos caminhos do imaginável. Ao procurar identificar imagens na aula de arte apresentei em imagens as escolas, as professoras, as próprias imagens. Ao iniciar esta pesquisa com o objetivo de constatar o uso de imagens da arte contemporânea nas aulas de arte, surgiram as primeiras perguntas: A arte contemporânea está presente na aula de arte? Professores de arte utilizam imagens da arte contemporânea para apresentar aos seus alunos? As indagações se ampliaram.

Encontrei lugares, escolas, professoras, residências, outras imagens, antes mesmo das imagens usadas nas aulas de arte. Busquei e também descobri textos, conceitos, autores que contribuíram para dar sentido às imagens encontradas e às fotografias. De Ana Mae Barbosa e Paulo Freire trouxe a conscientização das relações inseparáveis entre arte, educação e vida. Relações manifestas no conhecimento cotidiano, nas histórias diárias, nas múltiplas 
produções visuais, que têm sido valorizadas no cenário da pós-modernidade. Compreendi com estes autores a importância da dissolução das fronteiras entre erudito e popular. Vivenciei seus conceitos com as professoras e entendi que a leitura de imagens está relacionada à leitura do mundo local e às experiências perceptivas dos professores e alunos. Compreendi com estes autores e vivenciei com as professoras a permissão de abrir espaços para produções desprezadas no âmbito institucional da arte e do ensino de arte.

Quando me perguntava sobre como incluir no ensino de arte e na formação de seus professores as inquietações e questionamentos que fazem parte da compreensão da pós-modernidade, estudei uma bibliografia que contribuiu para elaborar a idéia de que para a arte contemporânea estar na sala de aula é preciso que as produções dos professores sejam motivadoras de suas aulas, valorizando a cultura local em diálogo com os saberes da arte, permitindo conhecer a arte e sua história através da apreciação e dos percursos de produção. É necessário que os professores tenham a compreensão de diferentes contextos de produção em arte, capacidade de análise, abertura de pensamento e um complexo, diversificado e infinito repertório visual contextualizado.

Penso que os ideais da modernidade mais enfatizados no ensino de arte tais como expressão, produção artística e aspectos formais, e a pluralidade da pós-modernidade, abrangendo os contextos de origem da arte, das imagens, das produções culturais, assim como o contexto de apreciação - também estão com suas fronteiras diluídas.

A imagem fotográfica foi destacada como substância e objeto da pesquisa. No campo de análise optei por desenvolver ensaios que discutem as fotografias apresentadas. As leituras e interpretação de Elliot Eisner e Roland Barthes foram fundamentais para este processo. Utilizei os critérios de avaliação desenvolvidos por Eisner para a proposta Arts-Based Educational Research - ABER, transformando-os nas perguntas: O que revela? O que produz? O que aprofunda? 
O que amplia? Associei a estas perguntas, como referencial de análise, os termos de Roland Barthes studium e punctum.

Durante o processo de desenvolvimento dos ensaios, além dos encontros com as fotografias e bibliografia, outro encontro foi significativo: a revelação de uma história familiar esquecida, ou nunca contada. A fotografia onde o pão-porDeus é apresentado desencadeou outro interesse. Interesse em produzir, também, o pão-por-Deus, a meu modo. Interesse em aprofundar estudos sobre a relevância das histórias pessoais na formação profissional de professores e sobre a importância destas histórias no entendimento da arte contemporânea. Interesse em aprofundar conceitos sobre as representações da cultura do povo que se aproximam da arte contemporânea e as representações contemporâneas que incorporam o popular.

Começo a enunciar possibilidades abertas a novas investigações. Então, novas perguntas: Quando a arte se separa da produção popular se separa da vida? Quando se separa da vida precisa de interlocutor? Quando volta para a vida cotidiana, através da arte contemporânea, o público, os professores e os alunos não se apercebem da aproximação? 


\section{REFERÊNCIAS BIBLIOGRÁFICAS}

AGIRRE, Imanol. Teorias y prácticas em educación artística. Barcelona: Octaedro/EUB Universidad Pública de Navarra, 2005.

ARCHER, Michel. Arte contemporânea: uma história concisa. São Paulo: Martins Fontes, 2001.

BARBOSA, Ana Mae. Entre Culturas in: Naifs [entre culturas]. Bienal Naifs do Brasil. São Paulo: SESC, 2006.

BARBOSA, Ana Mae, COUTINHO, Rejane, SALLES, Heloisa. Artes Visuais: Da exposição à sala de aula. São Paulo: EDUSP, 2005.

BARBOSA, Ana Mae (org). Arte/educação contemporânea: consonâncias internacionais. São Paulo: Cortez, 2005. . (org.) Inquietações e mudanças no ensino da arte. São Paulo: Cortez, 2002. Tópicos utópicos. Belo Horizonte: C/Arte, 1998. .(org) Arte-educação: leitura no subsolo. São Paulo: Cortez, 1997. .(org). O ensino das artes nas universidades. São Paulo: EDUSP: CNPq, 1993. . A imagem no ensino da arte. São Paulo: Perspectiva:1991. Arte-Educação: conflitos e acertos. São Paulo: Max Limonad, 1984. Recorte e colagem: influência de John Dewey no ensino de arte no Brasil. São Paulo: Cortez, 1982.

Teoria e prática da Educação Artística, São Paulo: Cultrix, 1982. Arte-educação no Brasil: das origens ao modernismo. São Paulo: Perspectiva:1978.

BARONE, $\mathrm{T}$ e EISNER, E. (in press). Arts-based educacional research. In: Complementary methods for research in education. Washington,DC: American Educational Research Association. Obtido no site: www.fundarte.rs.gov em setembro de 2008.

BARTHES, Roland. Aula. São Paulo: Cultrix, 1978.

A câmara clara. Rio de Janeiro: Nova Fronteira, 1984.

BAUMAN, Zygmunt. Modernidade e ambivalência. Rio de Janeiro: Jorge Zahar, 1999. . O mal-estar da pós-modernidade. Rio de Janeiro: Jorge Zahar, 1998.

BELTING, Hans. O fim da história da arte: uma revisão dez anos depois. São Paulo: Cosac Naify, 2006.

BLANCHOT, Maurice. A conversa infinita. São Paulo: Escuta, 2001.

BRITO, Ronaldo. O moderno e o contemporâneo (o novo e o outro novo). In: Arte Brasileira Contemporânea. Caderno de Textos 1. Rio de janeiro: Funarte, 1980.

CALABRESE, Omar. A idade neobarroca. Lisboa: edições 70, 1987.

CAUQUELIN, Anne. Arte contemporânea: uma introdução. São Paulo: Martins Fontes, 2005.

. Teorias da arte.São Paulo: Martins Fontes, 2005.

CHARTIER, Roger (org) Práticas da leitura. São Paulo: Estação Liberdade, 1996.

CLARK, Roger. Art education: issues in postmodernist pedagogy. Reston, Virginia: National Art education Association - NAEA, 1996.

COCCHIARALE, Fernando. Quem tem medo da arte contemporânea? Recife: Ed. Massangana, 2006.

COLLARES, Cecília; MOYSES, Maria; GERALDI, João. Educação continuada: a política da descontinuidade. IN: Educação e sociedade. № 68/9. Campinas: CEDES, 1999.

CONTRERAS, José. Autonomia de professores. São Paulo: Cortez, 2002. 
DANTO, Arthur G. Após o fim da arte: a arte contemporânea e os limites da história. São Paulo: Edusp, Odysseus Editora, 2006.

. A transfiguração do lugar-comum. São Paulo: Cosac Naify, 2005.

DEWEY, John. John Dewey, the later works: 1925-1953, volume 10: 1934, Art as experience. Carbondale: Soouthern Illinois University Press, 1989.DIAMOND, P. e MULLEN, C. O educador pós-moderno. Lisboa: Instituto Piaget, 2004.

DUFRENE, Mikel. Estética e filosofia. São Paulo: Perspectiva, 1981, $2^{\underline{a}}$ ed.

EAGLETON, Terry. As ilusões do pós-modernismo. Rio de Janeiro: Jorge Zahar, 1998.

EDUCAÇÃO \& REALIDADE. Dossiê Arte e Educação. Arte, criação e aprendizagem. Porto Alegre V.30, n.2, jul./dez. 2005.

EFLAND. Arthur D. Uma história de la educacioón del arte. Barcelona: Paidós,2002.

EFLAND. Arthur D, FREEDMAN, Kerry \& STUHR, Patrícia. La educación en el arte posmoderno. Barcelona: Paidós,2003.

FAVARETTO, Celso F. Moderno, pós-moderno, contemporâneo: na educação e na arte. Livre-Docência. Faculdade de Educação, USP. 2004.

FOUCAULT, M. Ditos e escritos, v.II Org Manoel Barros da Motta, Rio de Janeiro: Forense, 2000.

FREIRE, Cristina. Arte conceitual. Rio de Janeiro: Jorge Zahar Ed., 2006.

FREIRE, Paulo. Pedagogia da autonomia: saberes necessários à prática educativa. São Paulo: Paz e Terra, 1996. Pedagogia do oprimido. Rio de Janeiro: Paz e Terra, 1987. . Educação como prática de liberdade. Rio de Janeiro: Paz e Terra, 1983. . Conscientização: teoria e prática da libertação. São Paulo: Moraes, 1980. Educação e mudança. Rio de Janeiro: Paz e Terra, 1979

GARDNER, James. Cultura ou lixo? Uma visão provocativa da arte contemporânea. Rio de Janeiro: Civilização Brasileira, 1996.

GATTI, Bernadete A. Grupo focal na pesquisa em Ciências sociais e Humanas, 2005. GUIMARÃES ROSA, João. Primeiras estórias. Rio de Janeiro: Nova Fronteira, 2001. GUINSBURG, J. e Barbosa, Ana Mae. O pós-modernismo. São Paulo: Perpectiva, 2005. HALL, Stuart. A identidade cultural na pós-modernidade. Rio de janeiro: DP\&A, 2000. HARVEY. David. Condição pós-moderna: uma pesquisa sobre as origens da mudança cultural. São Paulo: Loyola,1998.

JAMESON, Fredric.Pós-Modernismo - A lógica cultural do capitalismo tardio. São Paulo: Ática:1991.

KONESKI, Anita Prado. O estranhamento na arte contemporânea, in: educação estética e constituição do sujeito:reflexões em curso. ZANELLA, A. e outros (org). Florianópolis: NUP/CED/UFSC,2007.

KOSKO, Bart. Pensamiento borroso. Barcelona: Crítica, 1995.

KOSSOY, Boris. Fotografia e história. São Paulo: Ateliê Editorial, 2001.

LIMA,Maria Socorro Lucena. A formação contínua do professor nos caminhos e descaminhos do desenvolvimento profissional. Tese (Doutorado). Faculdade de Educação, USP. 2001. p.16-49.

LINS, Jacqueline Wildi. O Moderno nas Artes Plásticas Contemporâneas: Temas em Debate. Dissertação (Mestrado). Universidade do Estado de Santa Catarina, UDESC, 2001.

LIPOVETSKY, Gilles. Os tempos hipermodernos. São Paulo: Barcarolla, 2004.

LYOTARD,J.F. O pós-moderno explicado às crianças.Lisboa: Dom Quixote, 1993,2ªed.

MACHADO, Regina. Acordais: fundamentos teórico-poéticos da arte de contar histórias. São Paulo: DCL, 2004. 
MAFFESOLI, Michel. A contemplação do mundo. Porto Alegre: Artes e Ofícios, 1995. Elogio da razão sensível. Rio de Janeiro: Vozes, 1998.

MAGNANI, Maria do Rosário M. Em sobressaltos: formação de professora. Campinas : Editora da UNICAMP, 1993.

MANNRICH, Maria Eli Braga. Pão-por Deus: vivo na cultura brasileira. Florianópolis: Editora da UFSC, 2007.

MARÍN VIADEL. Ricardo. Investigación em educación artística. Granada: Universidad de Granada, Universidad de Sevilla, 2005.

MARTINS, Maria Helena (org). Rumos da crítica. São Paulo: SENAC São Paulo: Itaú Cultural, 2000.

MATURANA, Humberto. A ontologia da realidade. Belo Horizonte: Ed. UFMG, 1997.

MELO, Sônia Maria Martins de. Corpos no espelho: a percepção da corporeidade em professoras. Tese de Doutorado, 2001, PUC, Porto Alegre.

MERLEAU-PONTY, Maurice. O olho e o espírito. São Paulo: Nova Cultural, 1980.

MORIN, Edgar. Os sete saberes necessários à educação do futuro. São Paulo: Cortez; Brasília, DF: UNESCO, 2000.

NAZARIO, Luiz. Quadro histórico do pós-modernismo. In: GUINSBURG, J. e BARBOSA, Ana Mae. O pós-modernismo. São Paulo: Perpectiva, 2005.

NORRIS \& BENJAMIM. Interpretando / Pintura a arte da desconstrução, in: O que é desconstrução? Tradução livre de Neide Marcondes. London: Academy Ed, 1988.

NÒVOA, António. Vidas de professores. Portugal: Porto Editora, 1992.

NUNES, Cely do Socorro. Os sentidos da formação contínua. O mundo do trabalho e a formação de professores no Brasil. Tese (Doutorado). Faculdade de Educação da USP. 2000. p01-75.

OLIVEIRA, Ana Claudia. "Visualidade, entre significação sensível e inteligível". In:

Educação e Realidade. Porto Alegre: Universidade Federal do Rio Grande do Sul, 30(2): jul/dez 2005, p.116.

PAZ, Octávio. Marcel Duchamp ou o castelo da pureza. São Paulo: Perspectiva, 2004.

PERNIOLA, Mario. Do sentir. trad. de António Guerreiro, Lisboa: Editorial Presença, 1993.

PILLAR, Analice Dutra (org). A educação do olhar. Porto Alegre: Mediação, 1999.

PIMENTA, Selma \& GHEDIN, Evandro (org). Professor reflexivo no Brasil: gênese e crítica de um conceito. São Paulo: Cortez, 2005.

PIMENTEL, Lucia G. Limites em expansão: licenciatura em artes visuais. Belo Horizonte: C/Arte, 1999.

QUINTÁS, Afonso Lopez. Estética. Petrópolis: Vozes, 1992.

RAMALHO E OLIVEIRA, S. R. Leitura de Imagens para a Educação. São Paulo, Programa de Estudos Pós-Graduados em Educação e Semiótica/PUC, 1998, tese de doutorado p.p. 46-50.

RANCIÈRE, J. O mestre ignorante. Belo Horizonte: Autêntica, 2004.

ROUANET, Sérgio P. Mal estar na modernidade. São Paulo: Companhia das Letras, 1993.

SANT'ANNA, Affonso Romano de. Desconstruir Duchamp: arte na hora da revisão. Rio de Janeiro: Vieira \& Lent, 2003.

SANTIAGO, Silviano (sup) Glossário de Derrida. Departamento de Letras da PUC/RJ. Rio de Janeiro: F. Alves, 1976.

SCHULER, Fernando e SILVA, Juremir Machado (orgs). Metamorfoses da cultura contemporânea. Porto Alegre: Sulina, 2006.

SONTAG, Susan. Sobre fotografia. São Paulo: Companhia das Letras, 2004.

SOUZA, Ricardo Timm de. A filosofia e o pós-moderno: algumas questões e sentidos fundamentais. In: GUINSBURG, J. e BARBOSA, Ana Mae. O pós-modernismo. São Paulo: Perpectiva, 2005. 
THOREAU, Henry David. Caminhando. Rio de Janeiro: José Olympio, 2006.

TOMKINS, Calvin. Duchamp: uma biografia. São Paulo: Cosac Naify, 2004.

UBERQUOI, Marie-Claire. ?El arte a la deriva? Barcelona: Debolsillo, 2004.

ZAMBONI, Silvio. A pesquisa em arte: um paralelo entre arte e ciência. Campinas: Autores Associados, 1998

ZEICHNER, Kenneth M. A formação reflexiva de professores: idéias e práticas. Lisboa: Educa,1993. 